US Army Corps of Engineers ${ }_{\circledast}$

Engineer Research and

Development Center

Coastal Inlets Research Program (CIRP)

\title{
Wave Averaging for Scoping Level Estimates of Nearshore Berm Morphodynamics
}

Douglas R. Krafft, Brian C. McFall, Richard Styles, and

December 2019

Katherine E. Brutsché

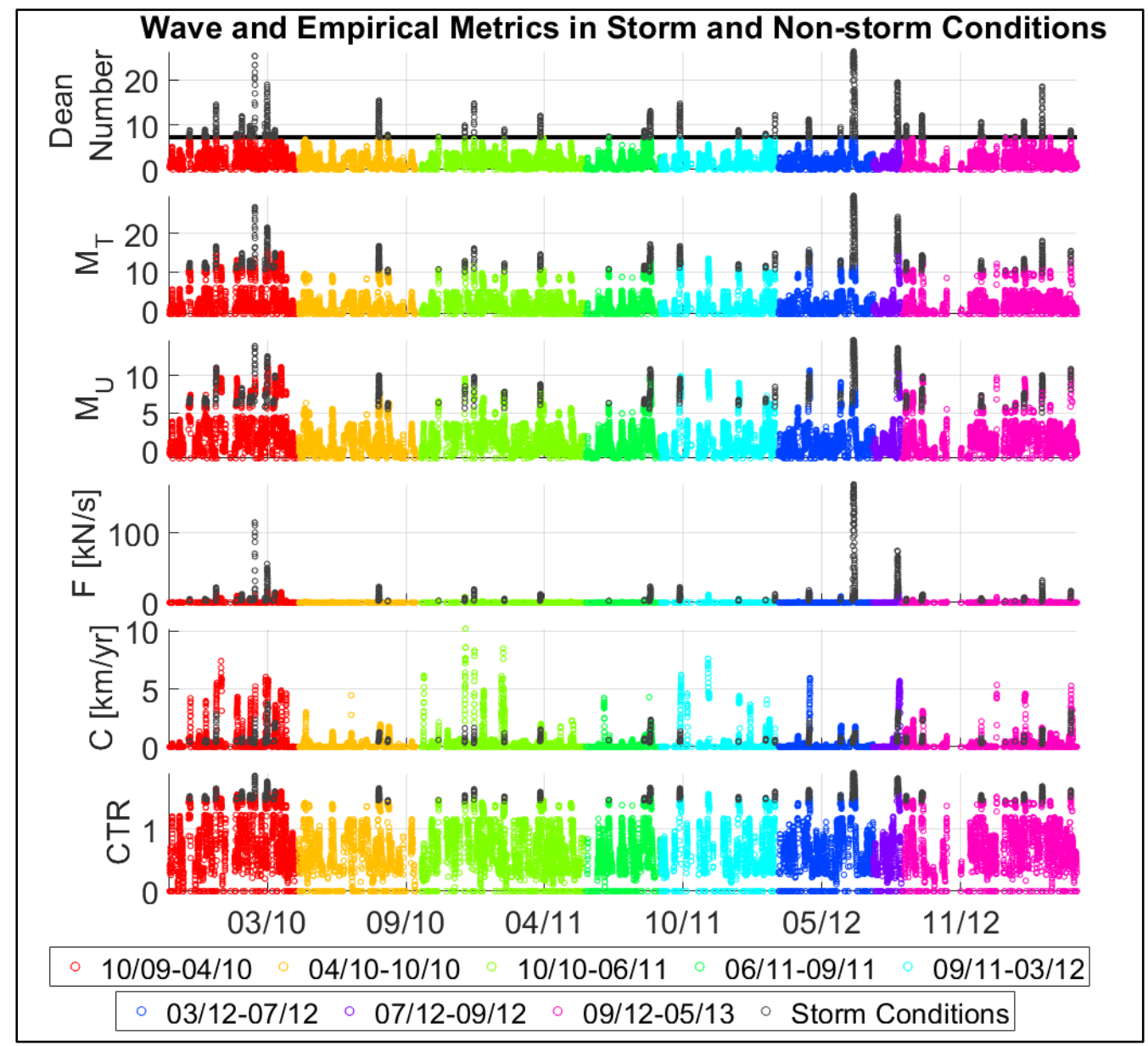

Approved for public release; distribution is unlimited. 
The US Army Engineer Research and Development Center (ERDC) solves the nation's toughest engineering and environmental challenges. ERDC develops innovative solutions in civil and military engineering, geospatial sciences, water resources, and environmental sciences for the Army, the Department of Defense, civilian agencies, and our nation's public good. Find out more at www.erdc.usace.army.mil.

To search for other technical reports published by ERDC, visit the ERDC online library at http://acwc.sdp.sirsi.net/client/default. 


\section{Wave Averaging for Scoping Level Estimates of Nearshore Berm Morphodynamics}

Douglas R. Krafft, Brian C. McFall, Richard Styles, and Katherine E. Brutsché

Coastal and Hydraulics Laboratory

US Army Engineer Research and Development Center 3909 Halls Ferry Road

Vicksburg, MS 39180-6199

Final report

Approved for public release; distribution is unlimited 


\section{Abstract}

Nearshore berms beneficially use dredged sediment to retain sediment in the littoral system, add material to the beach profile, and potentially dissipate energy from large erosive waves. Scoping level estimates of nearshore berm morphodynamics could provide useful information to assist coastal engineers and planners. Methodologies are presented to use long records of wave hindcast data to determine representative peak and mean wave climate data for scoping level nearshore berm morphodynamic estimates. Representative mean wave climate data are selected from distributions of averages over specified durations. Representative peak wave climate data are selected from distributions of quarter year averages. The relevance of combinations of wave parameters to nearshore berm morphodynamics is addressed with further analysis of a large nearshore berm at Fort Myers Beach, FL. Estimates of nearshore berm morphodynamics were quantified from survey data. The migration direction of the case study nearshore berm was found to be described by the ratio of storm to non-storm wave energy flux time integrals. Evidence suggesting that the net volume of sediment transported in the littoral zone between surveys may be proportional to the time integral of the non-storm wave energy flux is also presented.

DISCLAIMER: The contents of this report are not to be used for advertising, publication, or promotional purposes. Citation of trade names does not constitute an official endorsement or approval of the use of such commercial products. All product names and trademarks cited are the property of their respective owners. The findings of this report are not to be construed as an official Department of the Army position unless so designated by other authorized documents. 


\section{Contents}

Abstract........................................................................................................................ if

Figures and Tables...........................................................................................................

Preface ..................................................................................................................................vii

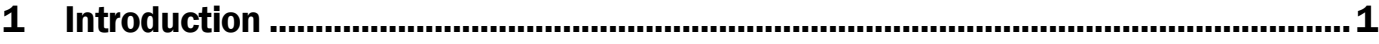

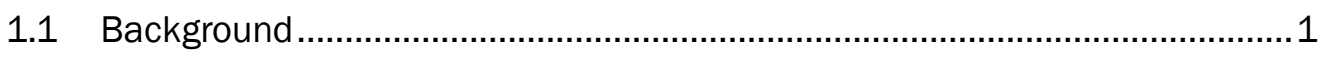

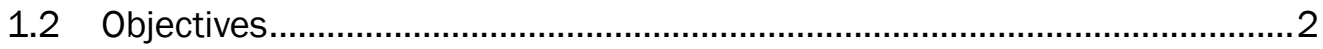

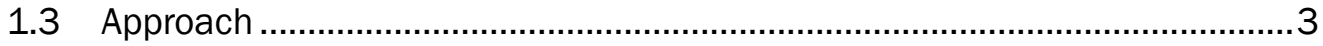

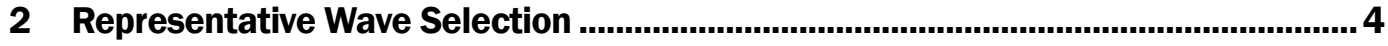

2.1 Timescales of nearshore berm morphodynamics ....................................... 4

2.2 Representative wave time series of equal duration ...................................... 5

2.3 Peak wave climate and the representative storm quarter ............................ 7

2.4 Representative wave climate estimate comparisons.....................................9

3 Predictions of Wave Impact on Nearshore Berms ...............................................13

3.1 Wave characteristics related to nearshore berm morphodynamics........... 13

3.1.1 Acquiring site wave information ...................................................................... 14

3.1.2 The sediment mobility index.............................................................................. 15

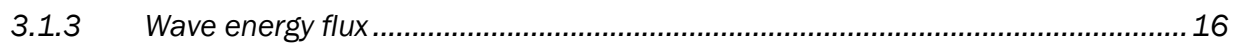

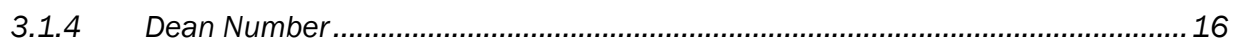

3.1.5 Nearshore berm migration coefficient............................................................. 17

3.1.6 The cumulative transport rate ........................................................................ 18

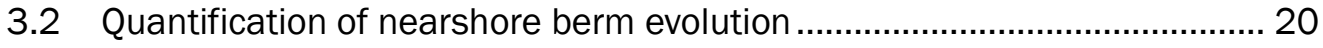

3.2.1 Nearshore berm height.................................................................................... 21

3.2.2 Nearshore berm migration rate ................................................................... 21

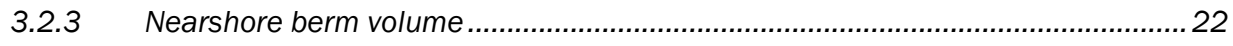

4 Nearshore Berm Morphodynamics Case Study ...................................................25

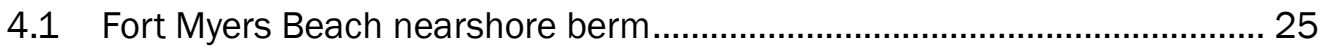

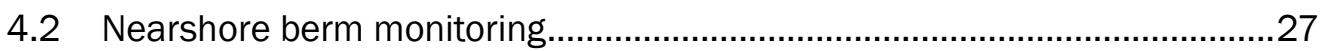

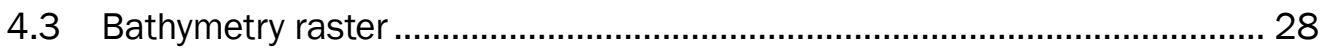

4.4 Alongshore averaged elevation profiles ................................................ 34

5 Case Study Waves and Nearshore Berm Morphodynamics...................................42

5.1 Hydrodynamics during Fort Myers Beach nearshore berm lifespan ........... 42

5.2 Storms, Dean Number, wave energy flux, and migration direction ...............47

5.3 Non-storm wave energy flux and nearshore berm morphodynamics.......... 53

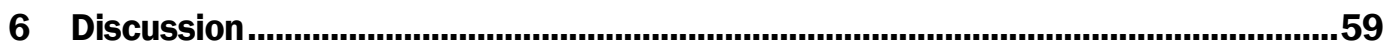

6.1 Relevant timescales for nearshore berm evolution.................................59 
6.2 Relevant metrics for nearshore berm cross-shore migration

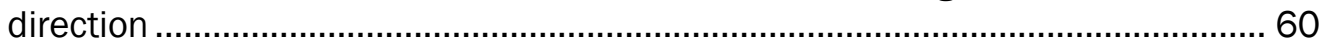

6.3 Relevant metrics for nearshore berm morphodynamics..............................61

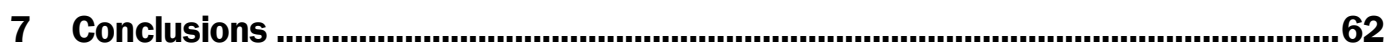

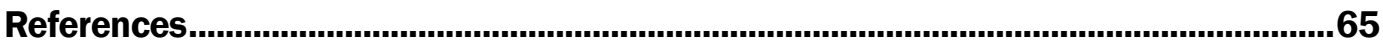

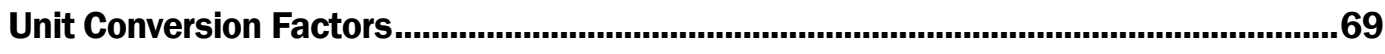

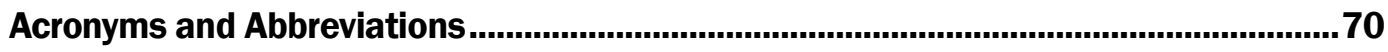

Report Documentation Page 


\section{Figures and Tables}

\section{Figures}

Figure 1. Distribution and central tendency measures of annual mean mobility numbers transformed from Wave Information Services (WIS) station 63218 to a water depth of $8 \mathrm{~m}$.

Figure 2. Maximum and mean average mobility numbers versus averaging window size. Wave information is transformed from WIS station 63218 to a depth of $8 \mathrm{~m}$.

Figure 3. WIS station 63218, offshore of Duck, NC, 8 m depth, quarter-year mean mobility number return intervals. 8

Figure 4. WIS stations 63218, 73295, and 83066 site map.

Figure 5. Distributions and central tendency measures of mobility numbers averaged over $0.25(\mathrm{~A}), 0.5(\mathrm{~B}), 1$ (C), and 2 (D) year overlapping periods offshore of Duck, NC. Transformed from WIS station 63218 to a water depth of $8 \mathrm{~m}$.

Figure 6 . Distributions and central tendency measures of mobility numbers averaged over $0.25(\mathrm{~A}), 0.5(\mathrm{~B}), 1(\mathrm{C})$, and 2 (D) year overlapping periods offshore of Fort Myers Beach, FL, from WIS station 73295 to a water depth of $2 \mathrm{~m}$.

Figure 7. Distributions and central tendency measures of mobility numbers averaged over $0.25,0.5,1$, and 2 year overlapping periods offshore of San Francisco, CA, from WIS station 83066 to a water depth of $12 \mathrm{~m}$

Figure 8. Quarter-year average normalized mobility number return intervals for WIS stations 63218, 73295, and 83066.

Figure 9. Nearshore berm height.

Figure 10. Nearshore berm centroid distance offshore....................................................22

Figure 11. Nearshore berm cross-sectional area..............................................................23

Figure 12. Nearshore berm gross cross-sectional area change.

Figure 13. Fort Myers Beach study area and beach and nearshore survey positions (red transects - May to October 2009; blue transects - April 2010 to May 2013).

Figure 14. (a) interpolated 05/2009 pre-construction survey, (b) interpolated 10/2009 post-construction survey, (c) elevation difference between preconstruction and post-construction surveys

Figure 15. Example USF-CRL profile 32 extrapolation to $275 \mathrm{~m}$ offshore of preconstruction shoreline.

Figure 16. Elevation differences between extrapolated bathymetry data and preconstruction survey for each USF-CRL survey and respective cross-shore data extents.

Figure 17. Elevation differences from the pre-construction survey for all surveys of the nearshore berm at Fort Myers Beach. Horizontal black lines indicate the same position across surveys. Dashed lines indicate shorelines (MSL).

Figure 18. Mean cross-shore elevation profile.

Figure 19. Littoral zone elevation alongshore standard deviation. 
Figure 20. Littoral zone and foreshore mean cross-shore elevation profile difference from pre-construction survey

Figure 21. Mean profile elevation change between surveys.

Figure 22. Mean profile elevation change between surveys relative to profile volume.

Figure 23. Estimated significant wave height, peak period, cosine of wave angle, and wave energy flux between survey dates. Wave characteristics were transformed from WIS station 73295 to depth-induced breaking.

Figure 24. Dean Number, mobility index, migration coefficient, and cumulative transport rate estimates between surveys Wave characteristics were transformed from WIS station 73295 to depth-induced breaking.

Figure 25. Dean Number, mobility index, wave energy flux, migration coefficient, and cumulative transport rate estimates between Fort Myers beach surveys. Wave characteristics were transformed from WIS station 73295 to depthinduced breaking.

Figure 26. Dean Number, significant wave height, peak period, cosine of wave angle estimate time series between Fort Myers beach surveys transformed from WIS Station 73295 to depth-induced breaking.

Figure 27. Storm wave statistics across all combinations of consecutive timespans and observed migration directions.

Figure 28. The relationship between gross or corrected gross littoral zone volume changes and non-storm wave energy flux integrals.

\section{Tables}

Table 1. WIS station 73295 wave climate data between nearshore berm surveys...........45

Table 2. WIS station 73295 empirical sediment transport and empirical bar morphodynamic metrics between nearshore berm surveys transformed to depthinduced breaking.

Table 3. Storm wave statistics between surveys at Fort Myers Beach for wave information transformed from WIS station 73295 to depth-induced breaking.

Table 4. Storm wave statistics across consecutive timespans with different migration directions.

Table 5. Non-storm wave energy flux integral and gross littoral zone volume change. 


\section{Preface}

This study was conducted for Headquarters, US Army Corps of Engineers (HQUSACE), Washington, DC, under the USACE Coastal Inlets Research Program (CIRP), "Inlet Geomorphic Evolution" work unit, as part of the USACE Navigation Program, under Funding Account Code U4362900, AMSCO Code 06000o. The CIRP is funded by the Operation and Maintenance Navigation Business Line of HQUSACE and is conducted by the US Army Engineer Research and Development Center (ERDC), Coastal and Hydraulics Laboratory (CHL), Navigation Division, Coastal Engineering Branch, Vicksburg, MS.

At the time of publication of this report, Ms. Lauren M. Dunkin was Chief, Coastal Engineering Branch; Dr. Jacqueline S. Pettway was Chief, Navigation Division; Dr. Tanya M. Beck was CIRP Program Manager; Mr. Kareem S. El-Naggar was Chief, HQUSACE Navigation Branch, and Navigation Business Line Manager; and Mr. Charles E. Wiggins, CHL, was ERDC Technical Director for Navigation. Dr. Ty V. Wamsley was Director of CHL, and Mr. Jeffrey R. Eckstein was Deputy Director of CHL.

The Commander of ERDC was COL Teresa A. Schlosser, and the Director of ERDC was Dr. David W. Pittman. 


\section{Introduction}

\subsection{Background}

The strategic placement of dredged sediment in the nearshore is an increasingly utilized technique to beneficially use dredged sediment that aligns with the principles of Regional Sediment Management (RSM) and Engineering With Nature ${ }^{\circledR}$. A nearshore berm is a specific type of strategic placement that intentionally places the dredged sediment in the nearshore in the shape of a mound or an elongated bar. Nearshore berms have also been called nearshore mounds, artificial sand bars, and foreshore nourishments.

Nearshore berms can be active or stable. The two objectives of active berms are to reduce the energy expended on a coastline by altering the erosive hydrodynamic conditions and to add material to the existing profile. The natural winnowing of the fine material from the placed sediment can occur, and the larger sediment, during times of accretion, provides a sediment source for the beach profile. Active berms with high relief may dissipate energy of large, erosive storm waves by inducing breaking. Waves broken above the berm must reform and progress towards shore with less energy.

Historically, nearshore berms have been studied with field monitoring at several locations around the United States (e.g., Hands and DeLoach 1984; McLellan 1990; Andrassay 1991; Bodge 1994; Otay 1994; Mesa 1996; Johnson 2005; Barnard et al. 2009; Wang et al. 2013; Brutsché et al. 2014; Brutsché et al. 2017; McFall et al. 2017). Additionally, the migration of nearshore berms have been studied in two-dimensional and threedimensional physical models (e.g., Zwamborn et al. 1970; Vera-Cruz 1972; Gunyakti 1987; Hwung et al. 2010; Bryant and McFall 2016; Smith et al. 2017a,b).

The United States Army Corps of Engineers (USACE) produced several Dredging Research Technical Notes in the Dredging Research Program Technical Area 5, Management of Dredging Projects, for nearshore berm design guidance from 1990 to 1993 (McLellan 1990; McLellan et al. 1990; Burke and Allison 1992; Pollock and Allison 1993). The majority of these technical notes used numerical modeling and idealized nearshore berms 
for the design guidance. Hands and Allison (1991) used the depth of closure equations by Hallermeier $(1978,1981)$ to categorize the active and stable nearshore berms. This guidance has been used to estimate whether a nearshore berm will be active or stable.

More recently, the Sediment Mobility Tool (SMT) was developed to assist coastal engineers and planners by providing a better understanding of whether sediment placed in the nearshore will move and where it is likely to go (McFall et al. 2016). The SMT has been validated using historical nearshore berms ${ }^{1}$ and has been used in the analysis of current nearshore placement practices (Brutsché et al. 2017; McFall et al. 2017; Arnold et al. 2018).

Although the SMT estimates the frequency of mobility and general transport direction, a better understanding of evolution of nearshore berms is driven by these key stakeholder and regulatory agency questions:

1. Where and how fast will sediment placed in the nearshore migrate?

2. How will the shoreline respond to the sediment placed in the nearshore?

All nearshore berm research to date has been to better address these two questions, but much more research is required to fill the knowledge gaps to answer these questions.

\subsection{Objectives}

The objectives of this report are as follows:

1. Demonstrate a methodology for the development of statistical wave characteristics for time series input to morphological predictive models.

2. Investigate different metrics to help describe and possibly predict nearshore berm morphodynamics.

\footnotetext{
1 Priestas, A. M., B. C. McFall, K. E. Brutsché, E. C. Maloney, and D. F. Bucaro. In preparation. Performance of Nearshore Berms from Dredged Sediments: Validation of the Sediment Mobility Tool. ERDC/CHL Technical Note. Vicksburg, MS: US Army Engineer Research and Development Center.
} 


\subsection{Approach}

In this technical report, characteristic wave climate determination procedures for predictions of nearshore berm lifespans are discussed. Representative wave selection techniques are discussed independently from specific wave characteristics. Combinations of wave characteristics that have been suggested to be important are presented through wave and empirical nearshore berm metrics. The relevance of various combinations of wave climate traits to nearshore berm morphodynamics was investigated through comparisons of wave and empirical nearshore berm metrics to the morphology observed at the 2009 dredged material nearshore berm at Fort Myers Beach, FL. Correlations between Dean Number, wave energy flux, nearshore berm migration direction, and an approximation of nearshore berm net sediment transport are investigated further, and possible relationships are suggested. 


\section{Representative Wave Selection}

Scoping level berm evolution tools compute quantifiable metrics from basic site, sediment, and wave information. The morphologic potential of a particular wave relates to some combination of wave, local site, and bathymetric characteristics. Scoping level nearshore berm morphodynamic predictions may benefit from characteristic wave spectra selection. Wave spectra that induce typical nearshore berm responses are considered representative. Wave morphologic potential estimates over a given duration indicate which segments of long records of wave information best represent typical conditions. Criteria related to wave morphologic potential estimates are matched to select representative time series of a specified duration from long records of wave information.

The applicability of various wave and empirical nearshore berm response metrics to describe nearshore berm evolution is not well defined, so a variety of metrics were considered. Selection procedures are described for sediment mobility index $(M)$ for simplicity. The sediment mobility index describes velocity or shear stress relative to the critical value for sediment mobilization and is presented in section 3.1.2. After selecting a predictable metric to describe nearshore berm evolution, wave spectra related to characteristic nearshore berm response metrics may be computed by two general procedures: (1) wave spectra that represent the average conditions over the entire duration considered are determined as the time series with the most representative average (e.g., Styles et al. 2018), (2) wave spectra that represent the peak conditions expected over a given duration are determined from the return period of storm events based on the specified duration (e.g., Demirbilek et al. 2010). The importance of peak events or higher frequency ongoing processes is related to the timescales of nearshore berm morphodynamics.

\subsection{Timescales of nearshore berm morphodynamics}

Nearshore berms evolve as the result of a variety of wave-induced processes, the ratios between which may vary over time. The frequencies at which nearshore berms evolve are not necessarily known. Two approaches to describe nearshore berm morphodynamics were considered: underlying ongoing processes and episodic peak events. Underlying ongoing processes may be described by an average over the duration of interest. Episodic peak events may be described as the most 
extreme events expected over a given timespan. Storm events are known to cause substantial damage and induce substantial sediment transport (e.g., Sallenger 2000; Stockdon et al. 2013; Birchler et al. 2014); however, the impact on the nearshore relative to more frequent but less energetic events is unclear (e.g., Russell 1993; Bascom 1953). The selection of appropriate statistical processes to quantify nearshore berm response is dependent upon some understanding of the time scales and frequency at which wave forcing induces nearshore berm morphologic changes. A characteristic wave spectra does not necessarily represent a characteristic storm wave spectra, and vice-versa. Nearshore berms and sand bars have been observed to move onshore during non-storm conditions and offshore during storm conditions, suggesting different frequencies between onshore and offshore movement. As an example, the Duck, NC, field study presented in Larson and Kraus (1992) indicates that at that particular site, storms moved bars offshore at an approximate frequency of once every 2 months at the 1.6 meter $(\mathrm{m})$ depth and once every 4 months at the $3.6 \mathrm{~m}$ depth. The relationship between the impacts of storm and non-storm waves on nearshore berms may vary between locations, so both representative mean and peak approaches were investigated.

\subsection{Representative wave time series of equal duration}

If ongoing processes that occur frequently drive nearshore berm evolution, then characteristic nearshore berm response may be addressed with a wave spectra representing a timespan of equal length to the duration considered. For example, waves impacting a nearshore berm for 1 year may be predicted with the year of consecutive wave data most similar to the typical average over 1 year. Characteristic wave climate data over a timespan of length $N$ are predicted as the wave information from the record time period with the most representative average wave metric. An entire record of wave information may be sampled with overlapping or non-overlapping averaging windows to determine a distribution of averages over a specified duration $(N)$. With non-overlapping averaging windows of size $(w)$ matching the duration of interest $(N)$, the distribution of mobility numbers $\left(\bar{M}_{i}\right)$ (Figure 1) may be determined from the record of mobility numbers $\left(M\left(t_{j}\right)\right)$ following the equation

$$
\bar{M}_{i}=\frac{1}{w} \sum_{j=1+w \cdot(i-1)}^{i \cdot w} M\left(t_{j}\right)
$$


where

$$
\begin{aligned}
i & =1 \text { to the dataset length }(L) \text { divided by the window size }(w) \\
j & =\text { index within mobility number time series }(M) \\
w & =\text { search window size (in wave dataset time-steps) } \\
M & =\text { mobility number time series } \\
\bar{M}_{i} & =\text { distribution of mobility number averages over duration } w .
\end{aligned}
$$

The distribution of mobility numbers $\left(\bar{M}_{i}\right)$ may be determined from the record of mobility numbers $\left(M\left(t_{j}\right)\right)$ with overlapping averaging windows (Figure 1), following the equation

$$
\bar{M}_{i}=\frac{1}{w} \sum_{j=1+s \cdot(i-1)}^{w+s \cdot(i-1)} M\left(t_{j}\right)
$$

where

$$
\begin{aligned}
i= & 1 \text { to the window size }(w) \text { less than the ratio of the dataset } \\
& \text { length }(L) \text { and step size }(s) . \\
s= & \text { step size. }
\end{aligned}
$$

Figure 1. Distribution and central tendency measures of annual mean mobility numbers transformed from Wave Information Services (WIS) station 63218 to a water depth of $8 \mathrm{~m}$.

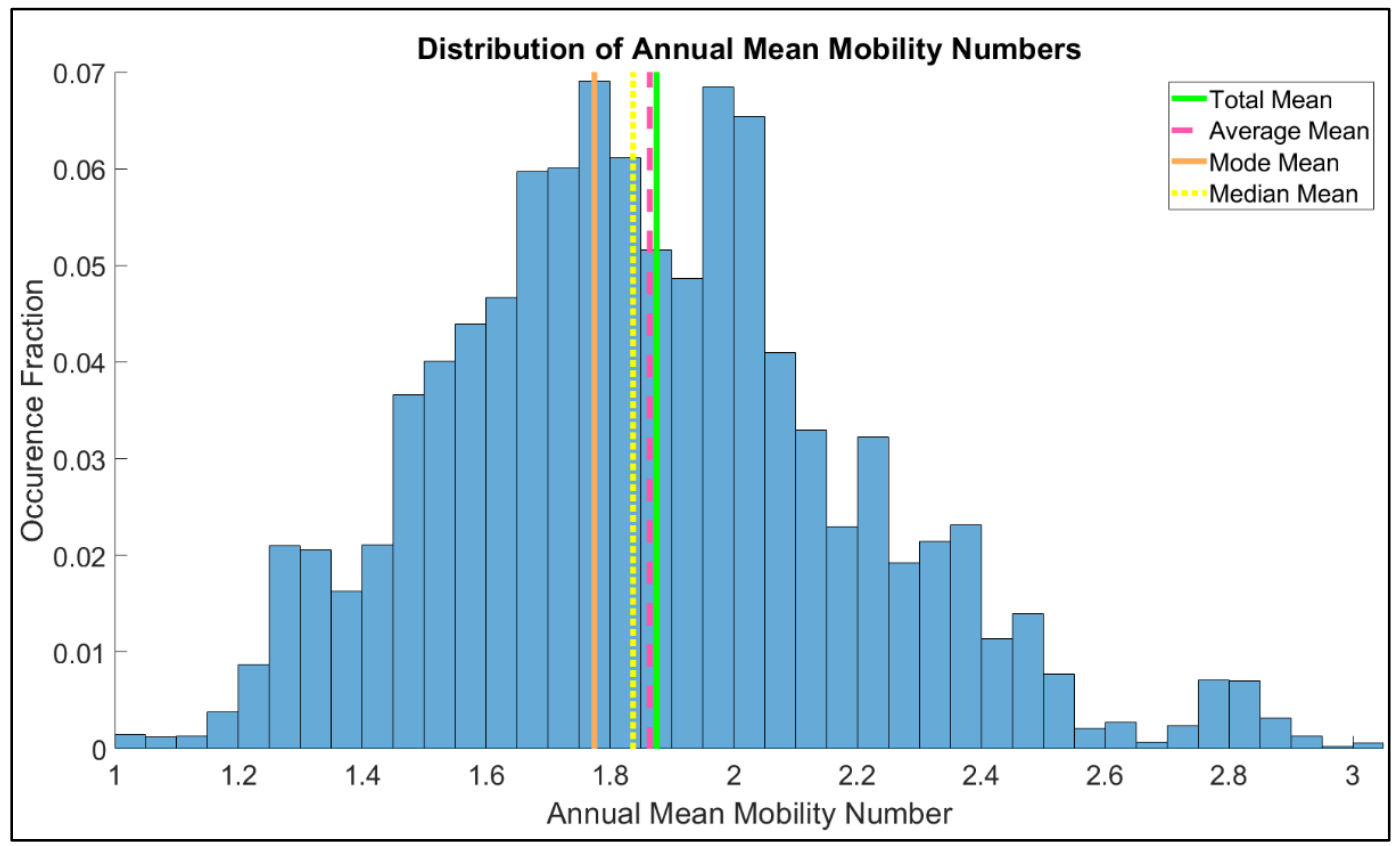


The appropriate degree of averaging window overlap depends on the dataset and the application. Unnecessarily high overlap can reduce the independence of consecutive averages, but insufficient overlap can limit window selection flexibility. Mobility number sensitivity to averaging window overlap is addressed through comparisons of mean and peak annual average mobility numbers estimated near the US Army Engineer Research and Development Center, Coastal and Hydraulics Laboratory, Field Research Facility (FRF), Duck, NC, at a depth of $8 \mathrm{~m}$ onshore of WIS point 63218 (Figure 2). Non-overlapping windows appear inadequate to select a time series representing the peak yearly average mobility number. All averaging windows considered appear adequate to capture the mean averaged mobility number in this specific case (Figure 2 - unfilled circles). The shortest step size considered (7 days) appears to best capture the peak annual average (Figure 2 - red line). The peak selection capability of an averaging window technique is related to the ability to capture the distribution of averages.

Figure 2. Maximum and mean average mobility numbers versus averaging window size. Wave information is transformed from WIS station 63218 to a depth of $8 \mathrm{~m}$.

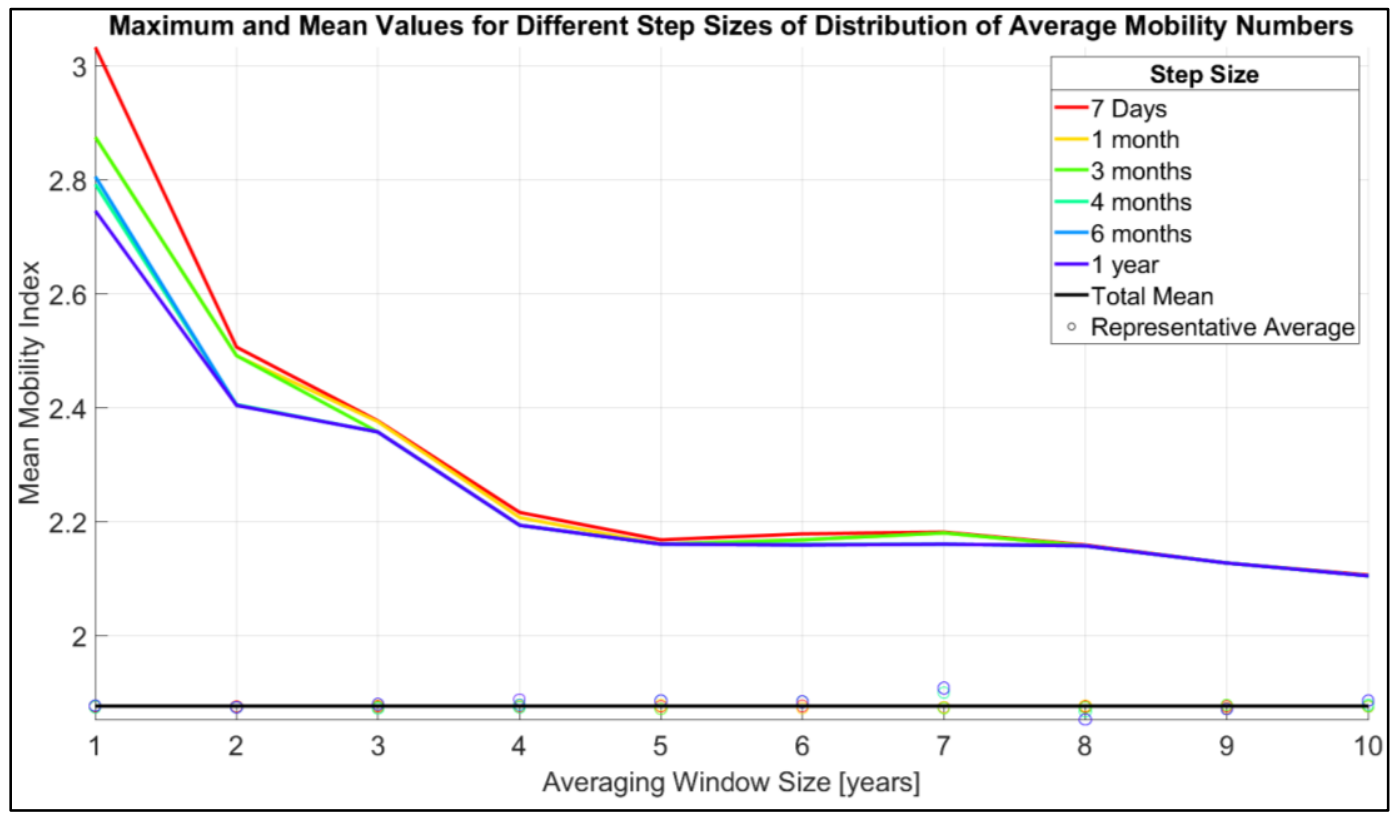

\subsection{Peak wave climate and the representative storm quarter}

Characteristic wave spectra for a duration $N$ may also be predicted as the representative storm quarter through a modification of the storm quarter selection procedure of Demirbilek et al. (2010). Average mobility indices were computed for non-overlapping 91.33-day segments representing 
quarter years. The time series of quarter-year mobility indices was ranked in descending order to compute mobility indices $\left(M_{R_{i}}\right)$ for each exceedance probability return period $\left(T_{R_{i}}\right)$. Return periods were calculated as the ratio between the duration of the record $\left(T_{S}\right)$ and the individual mobility number rankings $\left(n_{i}\right)$ (Equation 4$)$.

$$
T_{R_{i}}=\frac{T_{s}}{n_{i}}
$$

where

$i=1$ to 0.25 year less than the ratio of the length of the dataset $(N)$ and the number of points per quarter year $T_{R_{i}}=$ storm quarter return period

$T_{s}=$ record duration

$n_{i}=$ individual storm quarter mobility number rankings.

The storm quarter with the nearest mean mobility number return period may be selected to determine the representative wave conditions for a specified duration (Figure 3). The season with an average mobility number closest to the quarter-year average typically exceeded only once in the specified duration $N$ may represent the expected storm conditions averaged over a quarter year.

Figure 3. WIS station 63218, offshore of Duck, NC, $8 \mathrm{~m}$ depth, quarter-year mean mobility number return intervals.

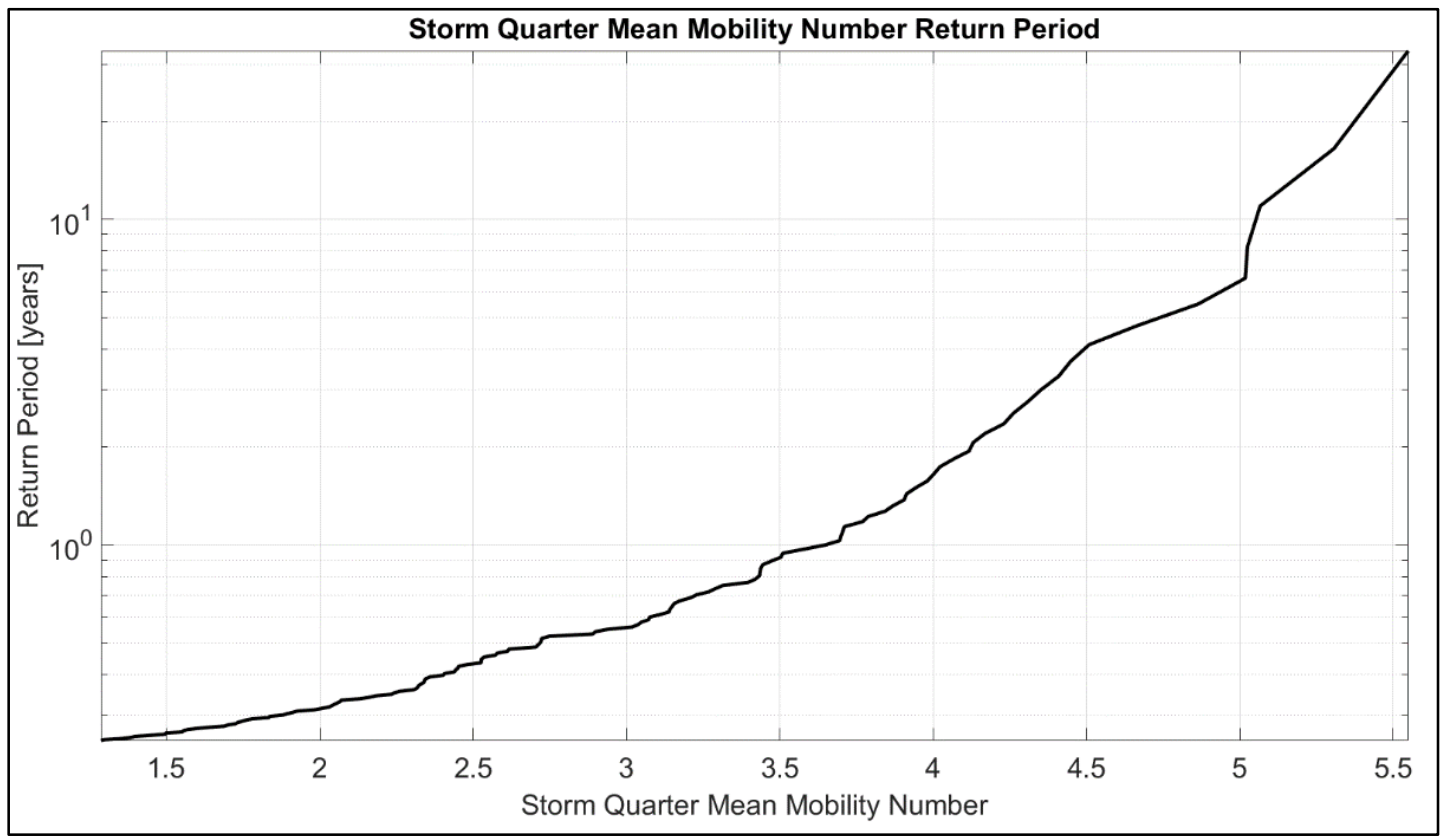




\subsection{Representative wave climate estimate comparisons}

In addition to the relevance of particular wave metrics to descriptions of nearshore berm morphodynamics, the applicability of various wave climate estimates also depends on the locations and durations considered. The estimated mobility numbers at three WIS stations in different wave environments were compared to begin to illustrate a broader range of applicability for the methodologies presented in sections 2.2 and 2.3. WIS station 73295, offshore of Fort Myers Beach (Figure 4), was analyzed for use in the case study in Chapters 4 and 5 . Wave data from WIS station 73295 are transformed to a depth of $2 \mathrm{~m}$ to reflect the placement depth of the nearshore berm at Fort Myers Beach. WIS station 63218, offshore of Duck, NC (Figure 4), was selected to represent wave conditions in the South Atlantic and contrast the wave conditions in the Gulf of Mexico at Fort Myers Beach. Wave data from WIS station 63218 are transformed to a depth of 8 m. WIS station 83066, offshore of Ocean Beach in San Francisco, CA (Figure 4), was selected because of the proximity to previous nearshore dredge material placements and the contrast with both Gulf and South Atlantic wave climates. Wave data from WIS station 83066 were transformed to a depth of $12 \mathrm{~m}$ to match the approximate placement depths of the dredge material nearshore berms discussed in Barnard et al. (2009).

Figure 4. WIS stations 63218,73295 , and 83066 site map.

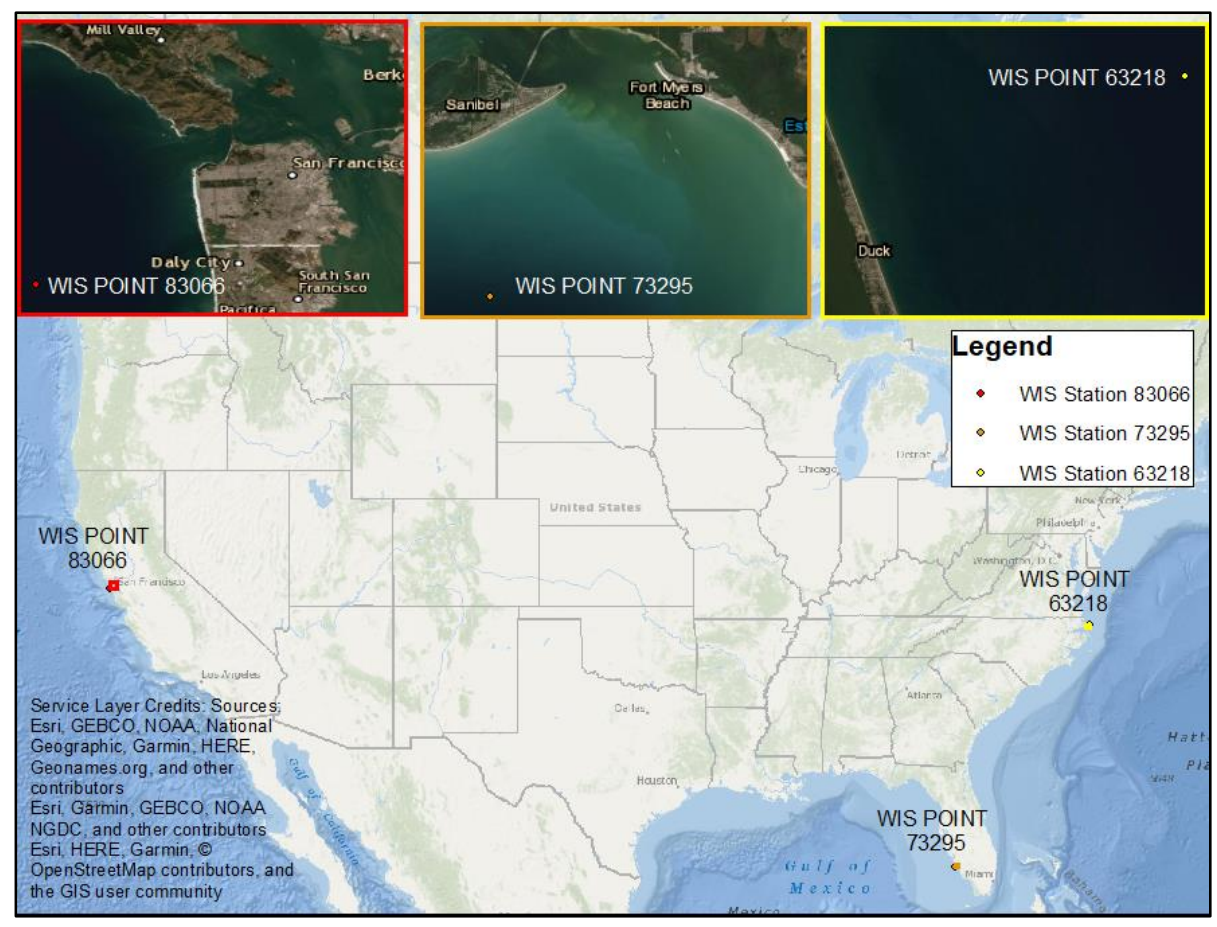


Mobility number distributions at all three of the considered WIS stations indicate that the mode and distribution tail estimates of 1-year averaging windows are substantially more relevant than mode and distribution tail estimates of 0.25-year averaging windows (Figure 5, Figure 6, Figure 7). Modes of mean mobility numbers were neither consistently greater than nor consistently less than average and median means at each of the three sites considered. Differences between mode, average, and median mean mobility numbers decreased with increasing averaging window size for all sites considered. Average and median mean mobility numbers for averaging windows of 0.25 year varied less from 1-year averaging windows than mode mobility numbers for averaging windows of 0.25 year. The tails of mean mobility number distributions changed substantially between the 0.25-year and 1-year averaging windows (Figure 5 A, C; Figure 6 A, C;

Figure $7 \mathrm{~A}, \mathrm{C}$ ). Averaging window duration appears to substantially impact predictions of mean mobility number probabilities other than central tendency measures, particularly averaging windows shorter than 1 year. Wave climate variation on seasonal time scales may have some impact on the increasing similarity of distributions of means averaged over a year or longer (Figure 5 C, D; Figure 6 C, D; Figure 7 C, D).

Figure 5. Distributions and central tendency measures of mobility numbers averaged over 0.25 (A), 0.5 (B), 1 (C), and 2 (D) year overlapping periods offshore of Duck, NC. Transformed from WIS station 63218 to a water depth of $8 \mathrm{~m}$.

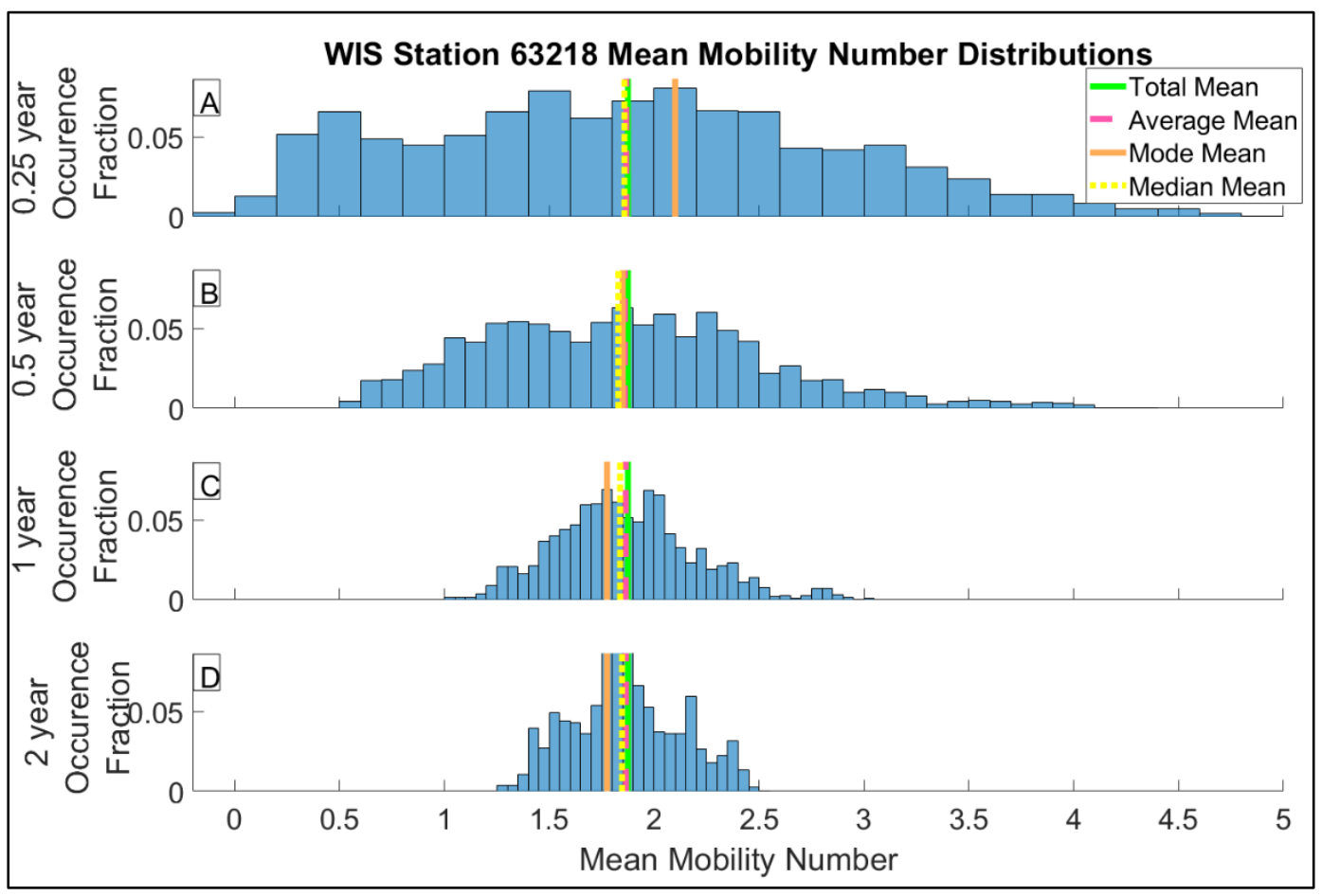


Figure 6. Distributions and central tendency measures of mobility numbers averaged over 0.25 (A), 0.5 (B), 1 (C), and 2 (D) year overlapping periods offshore of Fort Myers Beach, FL, from WIS station 73295 to a water depth of $2 \mathrm{~m}$.

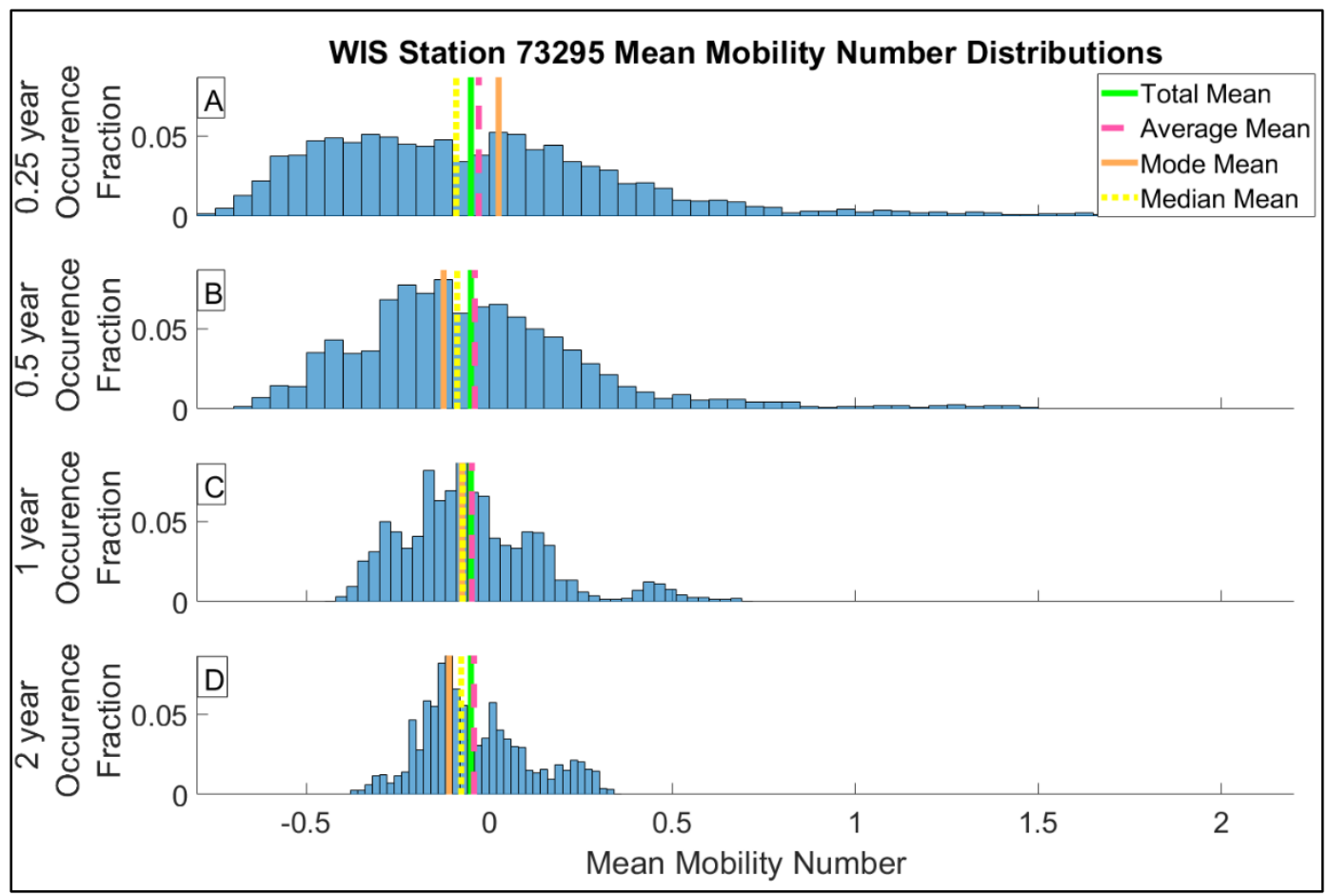

Figure 7. Distributions and central tendency measures of mobility numbers averaged over $0.25(A), 0.5(B), 1(C)$, and 2 (D) year overlapping periods offshore of San

Francisco, CA, from WIS station 83066 to a water depth of $12 \mathrm{~m}$.

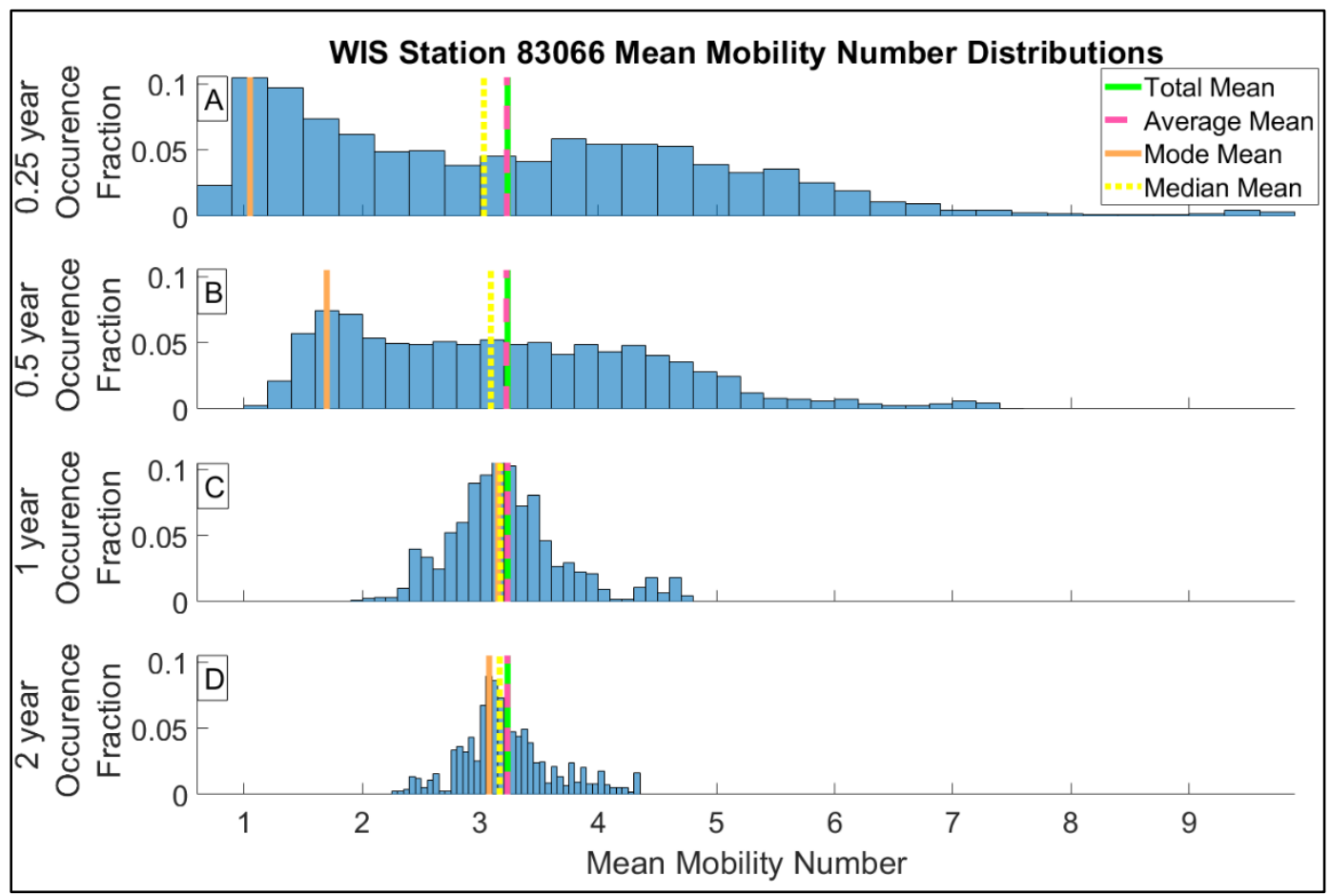


Quarter-year average mobility number return intervals were also analyzed for WIS stations 63218, 73295, and 83066 (Figure 8). Quarter-year average mobility numbers were normalized for each site by converting from mobility number to mobility number z-score. Mobility number z-scores were computed by subtracting the mean of the entire record and dividing by the standard deviation of the entire record. While mobility numbers are not expected to be normally distributed, mobility number z-scores allow an introductory comparison of distributions of mobility numbers between locations. The normalized quarter-year mean mobility numbers from analyzed WIS stations may indicate greater similarity between the relationships of extreme to non-extreme events with return periods of fewer than 5 years (Figure 8). The relationship between mobility numbers during extreme wave events and typical conditions appears to be site specific.

Figure 8. Quarter-year average normalized mobility number return intervals for WIS stations 63218, 73295, and 83066.

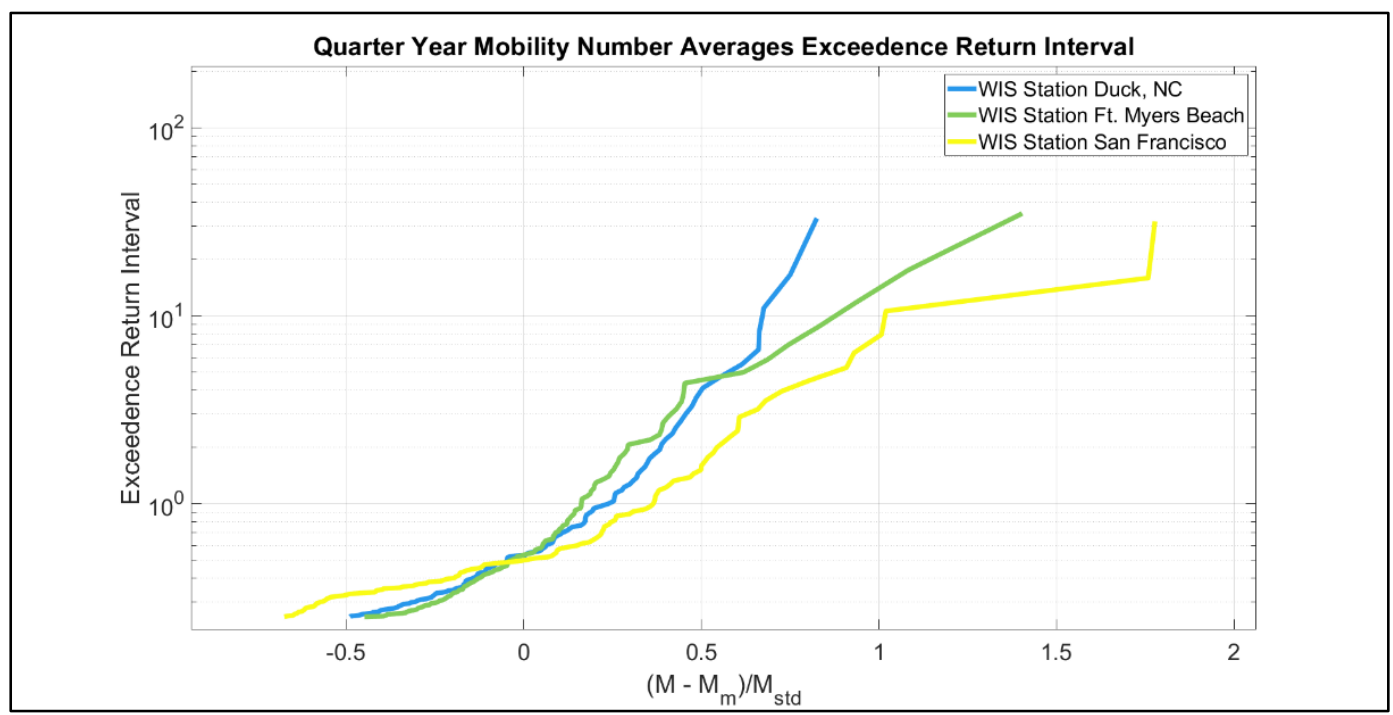




\section{Predictions of Wave Impact on Nearshore Berms}

Scoping level tools may be able to make statements on the lifespan of nearshore berm placements without extensive data, effort, or expertise requirements. This approach has similar user data requirements to those involved in the SMT (McFall et al. 2016) to improve usability. Single-valued wave metrics were used to describe the wave climate characteristics. Combinations of wave and sediment information were selected based on suggested relationships to sediment transport or bar evolution. The observed relationships between scoping level wave climate estimations and nearshore berm responses are investigated in Chapter 5. The difficulty of the problem and temporal extent and frequency of data considered here limit the formation of robust relationships between wave climate and nearshore berm response. Likelihoods of nearshore berm lifespans could be predicted if a reliable relationship between a wave climate estimate and nearshore berm response is identified.

\subsection{Wave characteristics related to nearshore berm morphodynamics}

Waves play a major role in nearshore sediment transport and thus in nearshore berm migration (Soulsby 1997). A variety of combinations of wave characteristics have been used to predict elements of nearshore berm morphodynamics. The lack of widespread correlation between distributions of wave height, direction, and angle limit the selection of characteristic wave climate data without consideration of representative wave characteristics and empirical transport estimates. The project focus was on the estimations of wave properties which produce characteristic nearshore berm responses, so combinations of wave characteristics which are related to nearshore berm responses were investigated. Specific wave metrics should be computed prior to averaging because many wave metrics depend on multiple wave characteristics and the multiplication of averages is not commutative. For arbitrary variables $x$ and $y$, the mean of the product of $x$ and $y$ is not necessarily equal to the product of the mean of $x$ and the mean of $y$.

Several studies have directly predicted elements of nearshore berm evolution properties from sediment and wave information. Empirically predicted nearshore berm morphodynamics information includes cross- 
shore migration direction and speed as well as quasi-equilibrium transport volume. Larson and Kraus (1992) empirically linked the distinction between onshore and offshore bar migration to a Dean Number limit of 7.2. Douglass (1995) empirically modified a derivation for sediment conservation using the Bagnold transport equation under second-order nonlinear monochromatic waves to obtain a berm migration speed. Hwung et al. (2010) empirically related Shields number to the total fraction of sediment volume transported from nearshore berms in the cross-shore direction through a regression of artificial bar morphology data from flume experiments.

The skill of empirical berm morphodynamic metrics at describing the evolution of a variety of nearshore berms is generally not well understood, but simple predictions are convenient options for preliminary scoping level analyses. The relationships between berm morphodynamics and wave, empirical sediment transport, or empirical berm response metrics were investigated to select wave conditions which correspond to characteristic nearshore berm responses. The applicability of several wave and empirical berm response metrics to berm evolution are discussed in Chapters 5 and 6.

\subsubsection{Acquiring site wave information}

Wave characteristic hindcast data are presently available between 1980 and 2014 at more than 5,670 stations near and throughout the US waters through WIS program. Given the spatial coverage of WIS stations, many nearshore placement locations will have at least 34 years of hindcast wave data. Future predictions may be made from hindcasts of previously observed data. The entire available time series of WIS hindcast wave data were transformed to the depth of interest for scoping level statements on wave climate statistics at a study site. Wave data were transformed from the WIS station to the study site following the methodology used in the SMT, which uses Snell's Law and conservation of energy flux, assuming shore parallel contours. Wave characteristics were modified to address wave height, wave angle, and water depth at wave breaking. Wave breaking was addressed by iteratively approaching the limiting wave height to a water depth ratio of 0.78 with Snell's law and shoaling and refraction coefficients. Significant wave height, peak period, and mean wave direction were estimated at the site over the entire record of wave data to compute wave metrics related to nearshore berm morphodynamics. 


\subsubsection{The sediment mobility index}

Sediment mobility index $(M)$, which is also referred to as mobility score or mobility number, represents the relationship between velocity or shear stress and a critical value for sediment mobilization. The SMT reports the mean mobility numbers and frequency of mobility numbers to address nearshore berm stability. Offshore WIS hindcast significant wave height $\left(H_{0}\right)$, parabolic fit spectral wave period $\left(T_{p}\right)$, and mean wave direction $(\theta)$ at an offshore location were transformed to the nearshore and combined with shoreline angle, grain size and site depth following the methodology outlined in McFall et al. (2016) to determine maximum bed shear stress $\left(\tau_{m x}\right)$ and maximum near-bottom velocity $\left(u_{\max }\right)$. In the SMT, maximum bed shear stress $\left(\tau_{m x}\right)$ is determined using the method for estimating bottom skin shear stress from linear wave theory outlined in Soulsby (1997) and Myrhaug (1998). The SMT computes maximum near-bottom velocity $\left(u_{\max }\right)$ from nonlinear, stream function wave theory following the methodology of Ahrens and Hands (1998). Mobility scores may be determined from both maximum bed shear stress (Equation 4) and maximum near-bottom velocity (Equation 5). Mobility scores determined through maximum bed shear stresses are calculated in the SMT as

$$
M_{\tau}=\frac{\tau_{m x}-\tau_{c r}}{\tau_{c r}}
$$

where

$$
\begin{aligned}
\tau_{m x} & =\text { maximum bed shear stress } \\
\tau_{c r} & =\text { critical shear stress. }
\end{aligned}
$$

Mobility scores determined through maximum near-bed velocities are calculated in the SMT as

$$
M_{u}=\frac{u_{\max }-u_{c r}}{u_{c r}}
$$

where

$$
\begin{aligned}
u_{\max } & =\text { maximum near-bottom velocity } \\
u_{c r} & =\text { critical near-bottom velocity }
\end{aligned}
$$

Critical shear stresses $\left(\tau_{c r}\right)$ are estimated following the procedure of Soulsby (1997) and Soulsby and Whitehouse (1997). Critical near-bottom 
velocities $\left(u_{c r}\right)$ are estimated following Ahrens and Hands (1998) (McFall et al. 2016).

\subsubsection{Wave energy flux}

Wave energy flux $(F)$ is defined as the depth-integrated rate at which work is done by the dynamic pressure per unit width in the direction of propagation averaged over a wave period (Dean and Dalrymple 1984). With linear wave theory and the dispersion relationship, wave energy flux $(F)$ may be expressed with the equations

$$
\begin{gathered}
\mathrm{F}=E C_{g} \\
E=\frac{1}{8} \rho g H^{2} \\
C_{g}=n C \\
n=\frac{1}{2}\left(1+\frac{2 k h}{\sinh 2 k h}\right)
\end{gathered}
$$

where

$$
\begin{aligned}
F & =\text { average wave energy flux } \\
E & =\text { total average wave energy per unit surface area } \\
C_{g} & =\text { wave group velocity } \\
H & =\text { wave height } \\
n & =\text { ratio of wave group velocity to wave-phase velocity } \\
C & =\text { wave phase velocity } \\
k & =\text { wave number } \\
h & =\text { water depth. }
\end{aligned}
$$

\subsubsection{Dean Number}

The Dean Number is a dimensionless parameter relating wave height to the product of sediment fall speed and wave period. The Dean Number is an important descriptor for a variety of nearshore morphodynamic processes including sand bar migration (Dalrymple 1992; Larson and Kraus 1992). Based on an investigation of over 200 sand bar profiles over a 9-year time space at the FRF, Larson and Kraus (1992) concluded that a limiting Dean Number of 7.2 distinguishes onshore from offshore sand bar 
migration. Onshore bar migration is empirically defined by the Dean Number limit

$$
\frac{H_{0}}{w T}<7.2
$$

where

$$
\begin{aligned}
H_{o} & =\text { offshore wave height } \\
w & =\text { sediment fall velocity } \\
T & =\text { wave period }
\end{aligned}
$$

Offshore bar migration is empirically defined by the Dean Number limit

$$
\frac{H_{0}}{w T}>7.2
$$

\subsubsection{Nearshore berm migration coefficient}

Nearshore berm migration rates have been related to wave characteristics through the nearshore berm migration coefficient presented in Douglass (1995). The derivation of the migration coefficient begins with a partial differential equation (PDE) to describe conservation of sediment in the cross-shore direction, which is expressed as

$$
\frac{\partial h}{\partial t}-\frac{\partial Q}{\partial x}=0
$$

where

$$
\begin{aligned}
h & =\text { elevation } \\
t & =\text { time } \\
Q & =\text { cross-shore volumetric transport rate } \\
x & =\text { cross-shore distance. }
\end{aligned}
$$

The PDE for cross-shore sediment conservation may be expanded with Stokes second-order wave theory and the Bagnold bedload transport model as expressed in terms of the time integral of instantaneous near-bottom water velocity by Bailard and Inman (1981). Assuming all motion is in the cross-shore direction, neglecting the wave changes across the mound, and omitting second order slope terms, the conservation of sediment on a bar is expressed in Douglass (1995) by the following equations: 


$$
\begin{gathered}
\frac{\partial h}{\partial t}+C \frac{\partial h}{\partial x}-\mathrm{D} \frac{\partial^{2} h}{\partial x^{2}}=0 \\
C=A \frac{9 \pi^{3}}{16} \frac{\rho g C_{f} \epsilon_{b}}{\left(\rho_{s}-\rho\right) a^{\prime} \tan \phi} \frac{H_{m o}{ }^{4} T_{p}}{L_{p}{ }^{4}}\left\{2 \operatorname{csch}^{5}\left(\frac{2 \pi h}{L_{p}}\right) \operatorname{sech}\left(\frac{2 \pi h}{L_{p}}\right)+\operatorname{csch}^{3}\left(\frac{2 \pi h}{L_{p}}\right) \operatorname{sech}^{3}\left(\frac{2 \pi h}{L_{p}}\right)\right\} \\
D=A \frac{9 \pi^{2}}{64} \frac{\rho g C_{f} \epsilon_{b}}{\left(\rho_{s}-\rho\right) \operatorname{at}^{\prime} \tan ^{2} \phi} \frac{H_{m o}{ }^{4} T_{p}}{L_{p}{ }^{3}} \operatorname{sech}^{2}\left(\frac{2 \pi h}{L_{p}}\right) \operatorname{csch}^{4}\left(\frac{2 \pi h}{L_{p}}\right)
\end{gathered}
$$

where

$$
\begin{aligned}
C & =\text { convection coefficient } \\
D & =\text { diffusion coefficient } \\
A & =\text { empirical correction coefficient } \\
C_{f} & =\text { empirical friction coefficient } \\
\epsilon_{b} & =\text { empirical transport efficiency coefficient } \\
\rho_{s} & =\text { sediment density } \\
a^{\prime} & =\text { ratio of total volume to volume of solids } \\
\phi & =\text { sediment internal friction angle } \\
H_{m o} & =\text { significant wave height } \\
T_{p} & =\text { peak period } \\
L_{p} & =\text { local wave length corresponding to peak period } \\
h & =\text { water depth. }
\end{aligned}
$$

The empirical correction factor $(A)$ typically ranges between 0.2 and 0.5 and is intended to be tuned to match observed migration speeds (Douglass 1997). In Douglass (1995), empirical friction coefficients $\left(C_{f}\right)$ were set to 0.005, empirical transport efficiency coefficients $\left(\epsilon_{b}\right)$ were set to 0.21 , volume to volume of solids ratios $\left(a^{\prime}\right)$ were set to 1.67 , and sediment internal friction angles $(\phi)$ were set to $32^{\circ}$ as typical values. Nearshore berm migration rates may be predicted directly as the convection coefficient (C) (Equation 14) (Douglass 1995). Nearshore berm profile evolution has been successfully modeled following the differential equation for cross-shore sediment conservation (Equation 13) at Silver Strand State Park, CA; however, migration rate predictions have been validated against a greater number of observations (Douglass 1995; Douglass 1997).

\subsubsection{The cumulative transport rate}

The cumulative transport rate is an empirical formula relating total crossshore sediment transport at artificial sand bars to Shields Number. 
Cumulative transport rates are calculated following an empirical equation from morphology and wave data of flume experiments with mobile artificial bars and planar fixed beds (Hwung et al. 2010). The cumulative transport rate quantifies the volume of sediment transported from a sand bar in the cross-shore direction between the initial condition and a quasiequilibrium state, and may be defined by the equation

$$
C T R=\frac{\int_{0}^{t_{m}} q_{x} d t}{A_{0}}=\frac{A_{t}}{A_{0}}=1-\frac{A_{r}}{A_{0}}
$$

where

$$
\begin{aligned}
q_{x} & =\text { cross-shore sediment transport rate induced from the bar } \\
t & =\text { time } \\
t_{m} & =\text { time elapsed from construction to quasi-equilibrium state } \\
A_{t} & =\text { cross-sectional area of sediment transported from initial area } \\
A_{o} & =\text { cross-sectional area of constructed bar } \\
A_{r} & =\text { cross-sectional bar area remaining in quasi-equilibrium state. }
\end{aligned}
$$

Following dimensional analysis and the omission of terms with insignificant variations between repeated tests in the same flume, regression of bar morphology data from flume experiments yielded a relationship of

$$
\begin{gathered}
C T R=0.45 \ln \left(\frac{\theta}{\theta_{c}}\right) \\
\theta=\frac{f_{w} u_{b}^{2}}{2(s-1) g d_{50}}
\end{gathered}
$$

where

$$
\begin{aligned}
\theta & =\text { shields number } \\
\theta c & =\text { critical Shields number for initial bar movement } \\
f w & =\text { wave friction factor } \\
s & =\text { relative sediment density } \\
u b & =\text { near-bed velocity. }
\end{aligned}
$$

The empirical relationship for the cumulative transport rate fit the collected data with an $R^{2}$ value of 0.825 . Initial bar movement critical Shields Number $\left(\theta_{c}\right)$ was empirically determined to be 0.027 , which is 
smaller than the typical critical Shields Number of sediment composing the bar $\left(\theta_{c}=0.05\right)$ (Hwung et al. 2010). Hwung et al. (2010) recommend estimating wave friction factors following the empirical formula proposed by Nielsen (1992); however, Shields Number $(\theta)$ may also be computed from normalized shear stress. Shields Number may be written in terms of maximum bed shear stress $\left(\tau_{m x}\right)$ as

$$
\boldsymbol{\theta}=\frac{\tau_{m x}}{\left(\rho_{s}-\rho\right) g d_{50}}
$$

where

$$
\begin{aligned}
\tau_{m x} & =\text { maximum bed shear stress } \\
d_{5 o} & =\text { median grain diameter }
\end{aligned}
$$

Maximum bed shear stress $\left(\tau_{m x}\right)$ was computed following the procedure used in the SMT (McFall et al. 2016). The cumulative transport rate provides a direct, though entirely empirical, estimate of the fraction of a nearshore berm which will be transported out of the placement area. Cumulative transport rate calculations have also been compared to the nearshore berm projects discussed in Otay (1994), Dean and Dalrymple (2002), and Barnard et al. (2009) as a predictor for mobility (Hwung et al. 2010). Cumulative transport rate was not indicated to relate to onshore or offshore transport direction.

\subsection{Quantification of nearshore berm evolution}

Several single-valued characteristics were used as approximate representations of nearshore berm evolution. Calculating an individual value to represent nearshore berm morphodynamics between two measurement times facilitates direct and quantitative comparisons with wave information. Nearshore berm evolution properties of interest include height, volume, and migration rate. Representations of nearshore berm morphodynamics may be calculated by a variety of methods depending on the available data. Nearshore berm morphodynamic metrics were calculated in this technical report following methods that were decided to best match the data available from the 2009 nearshore berm placement at Fort Myers Beach, FL, as discussed in Chapter 4. The collection of bathymetry data covering the study area at Fort Myers Beach prior to nearshore berm placement and the large size of the nearshore berm relative to triangulation errors permitted a description of the nearshore 
berm through subtractions of the first bathymetry raster from subsequent bathymetry data. Contrast between the nearshore berm and surrounding area was substantially increased, moving from an elevation to elevation difference perspective (Figure 14).

\subsubsection{Nearshore berm height}

Nearshore berm height may be used to represent the remaining portion of the placement, the protrusion from typical profile conditions, and possibly the extent to which the profile is out of equilibrium. Considering a single cross-shore profile that passes through the placement, the nearshore berm height $(h)$ is the maximum distance between pre and post-construction surveys (Figure 9). Larson and Kraus (1992) use a similar definition for bar height, determining maximum bar height as the peak vertical difference from a reference profile. From a planform perspective, the elevation difference peak of each alongshore row is averaged to calculate a total nearshore berm height.

Figure 9. Nearshore berm height.

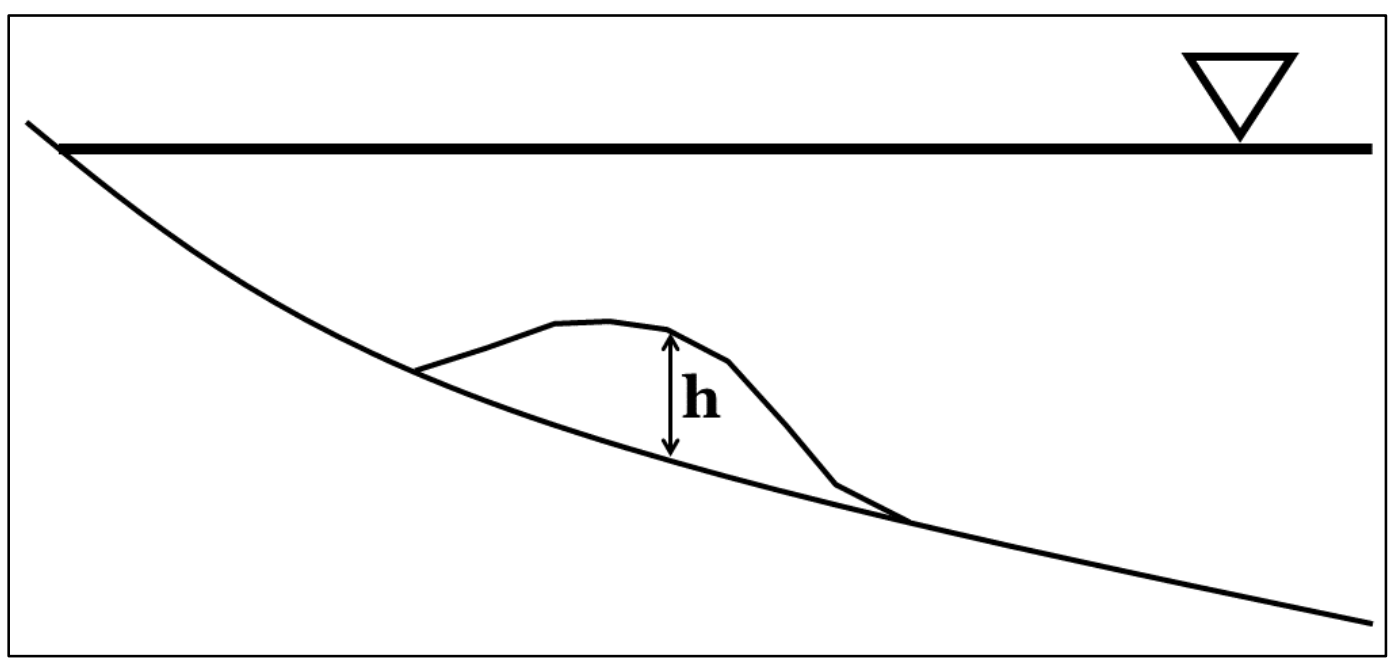

\subsubsection{Nearshore berm migration rate}

Nearshore berm evolution may be described by sediment transport in both the alongshore and the cross-shore directions. Alongshore sediment transport from berms has been observed as the diffusion of sediment downdrift of placements (Smith et al. 2015; Bryant and McFall 2016; Smith et al. 2017a,b), reducing the protrusion from an equilibrium beach profile. Cross-shore evolution of nearshore berms has been observed as driven by both diffusion and advective migration (Hands and Allison 
1991; Andrassey 1991; Douglass 1995; Cheng et al. 2015). Dean and Dalrymple (2002) present a similar framework for understanding beach fill deflation with alongshore spreading, background erosion, and crossshore profile equilibration.

Centroid position represents the cross-shore position of a nearshore berm, and the cross-shore component of the change in the nearshore berm centroid represents migration speed. Nearshore berm centroid position may be calculated from the difference between a profile and the preconstruction profile as the offshore distance $\left(x_{c}\right)$ of the centroid. (Figure 10). Migration speed for an individual profile may be calculated from the difference between consecutive offshore distances of nearshore berm centroids. Bar movement speed was calculated in Larson and Kraus (1992) as the difference in centroid distance offshore over the time difference. A single centroid for the entire nearshore berm at time $t$ may be computed as the centroid of the difference between an elevation raster from a survey at time $t$ and the survey before construction. A single migration rate for the entire nearshore berm may be calculated as the difference between the cross-shore positions of nearshore berm centroids divided by the time between post-construction surveys.

Figure 10. Nearshore berm centroid distance offshore.

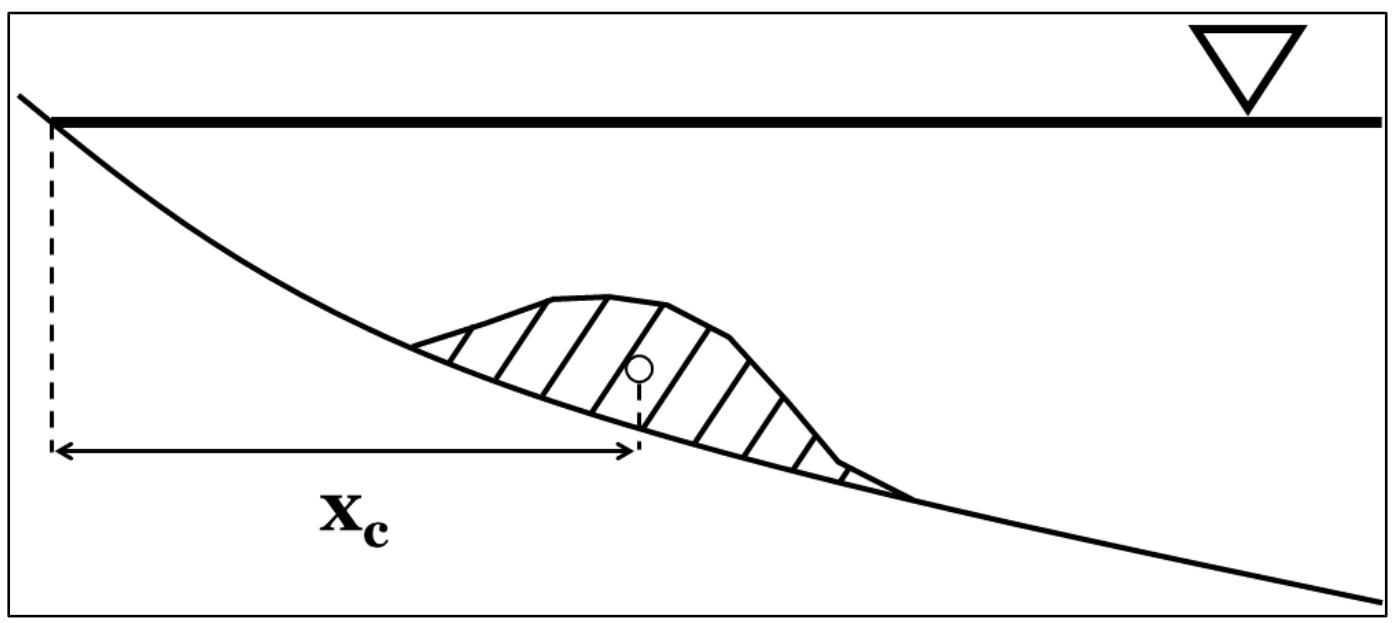

\subsubsection{Nearshore berm volume}

Nearshore berm volume $(V)$ is a representation of the remaining portion of a placement and may be represented as the integral of cross-sectional area (Figure 11). Nearshore berm cross-sectional area may be calculated by subtracting a specific profile from the pre-construction profile. Two variations of volume change are investigated. Total nearshore berm 
volume remaining within specified boundaries may be expressed as the alongshore integral of area $(A)$ between a profile and the pre-construction profile (Figure 11). Net nearshore berm volume change reflects transport outside of the sampled domain. Lossless nearshore berm migration, in which all sediment movement was within the sampled domain, would yield a net nearshore berm volume change $(\Delta V)$ of zero. Complete nearshore berm deflation, in which all sediment was transported out of the sampled domain, would yield a net nearshore berm volume change equal to the initial volume.

Figure 11. Nearshore berm cross-sectional area.

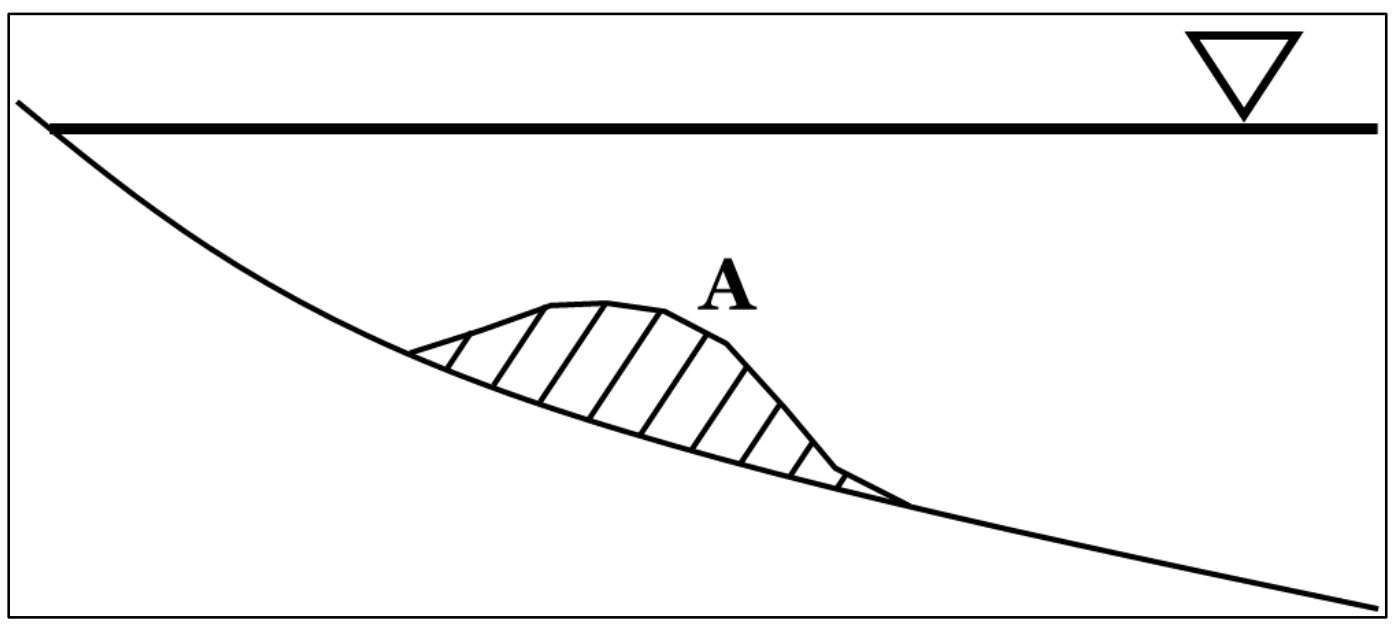

Gross volume change $\left(\Delta V_{g}\right)$ is a representation of the net quantity of transported sediment. The gross volume change of a single profile between two time-steps may be represented as a gross cross-sectional area change $\left(\Delta A_{g}\right)$ (Figure 12). Gross cross-sectional area change may be computed by integrating the absolute value of the difference between two profiles at each cross-shore position. Gross volume change may be calculated by integrating the absolute value of the difference between two elevations at each point in the bathymetry raster. The gross volume change of the complete deflation of a nearshore berm and transport outside of the domain would be equivalent to the volume of the placement, while the gross volume change of the migration of a nearshore berm without any sediment loss would be equal to twice the volume difference.

The sum of the gross volume change and the absolute value of the net volume change may be presented as a reasonable correction for the gross volume change to account for the double counting of transport within the domain. For example, if sediment were transported within and across the 
domain boundaries then the net volume change would only capture the sediment transported across the boundaries, the gross volume change would count the sediment transported across the boundaries once and the sediment transported within the boundaries twice, and the corrected gross volume change would count all of the transported sediment twice. The corrected gross volume change should be equal to twice the net sediment transport across the entire domain.

Figure 12. Nearshore berm gross cross-sectional area change.

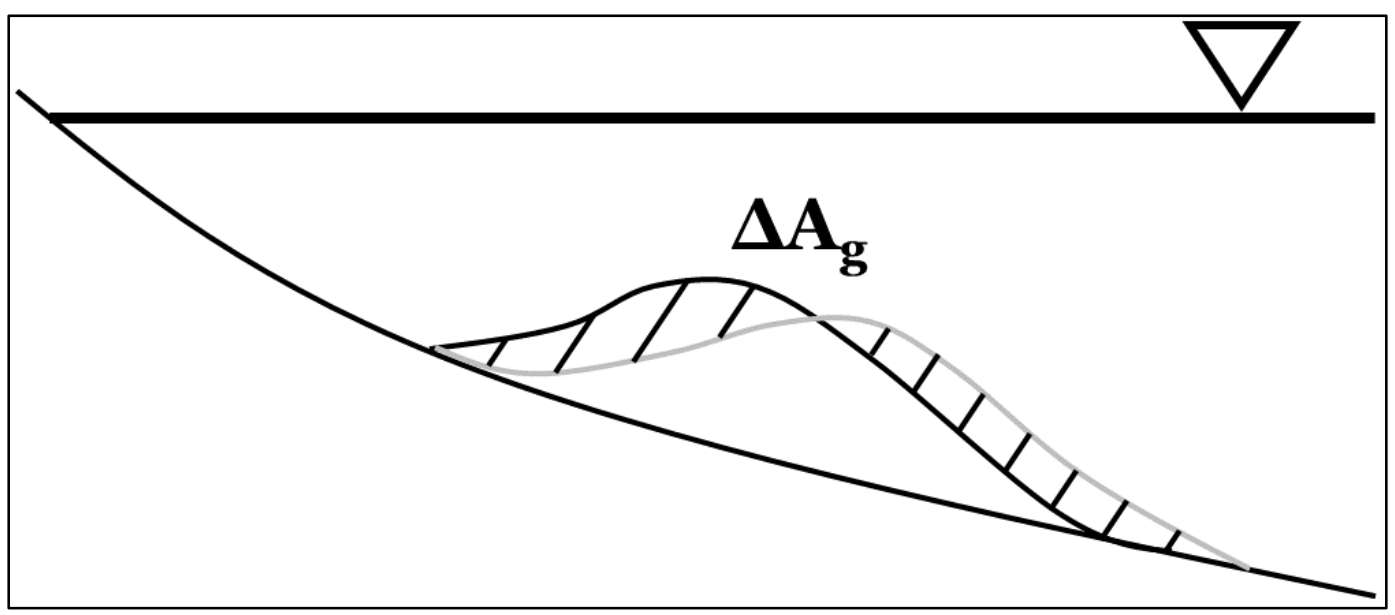




\section{Nearshore Berm Morphodynamics Case Study}

A variety of combinations of wave characteristics, which have been suggested to be important to various aspects of nearshore berm and bar morphodynamics, were investigated (Chapter 3), but no extensively validated general relationships between wave characteristics and nearshore berm morphodynamics were discovered. Various combinations of wave characteristics have been shown to govern some aspect of nearshore berm morphodynamics in a relatively limited set of applications, but no wave characteristic combination was determined that is widely applicable. The characteristic wave climate selection techniques discussed in Chapter 2 are generally independent of wave metrics and are not well suited for distinguishing between potentially relevant wave metrics.

The skill with which a wave characteristic represents typical nearshore berm morphodynamic conditions is entirely dependent on the relationship between wave metrics and nearshore berm morphodynamics. The relevance of various combinations of wave parameters to descriptions of the specific morphodynamics observed at a particular nearshore berm is addressed in this technical report through the investigation of a particular case study. Detailed elevation survey data that capture the evolution of a large nearshore berm were collected at Fort Myers Beach, FL. Nearshore berm morphologic change was quantified from survey data for comparison with estimated wave characteristics (Chapter 5 ).

\subsection{Fort Myers Beach nearshore berm}

In 2009, an approximately $120 \mathrm{~m}$ wide by $1 \mathrm{~m}$ high by $1,600 \mathrm{~m}$ long (approximately 175,000 $\mathrm{m}^{3}$ ) beneficial use nearshore berm was constructed approximately $200 \mathrm{~m}$ offshore of Fort Myers Beach, FL, in a water depth of approximately -2 m in the North American Vertical Datum of 1988 (NAVD88). The nearshore berm placement site was on the northern end of Estero Island, a low-lying and extensively developed barrier island on the Florida Gulf Coast (Figure 13). Sediment used in the nearshore berm was dredged from the federally maintained navigation channel at Matanzas Pass, located at the northern tip of the island. Typical grain sizes within the nearshore berm ranged from 0.16 millimeter $(\mathrm{mm})$ to $0.18 \mathrm{~mm}$. Brutsché (2011, 2014), Brutsché et al. (2014), and Wang et al. (2013) describe the 2009 nearshore berm at Fort Myers Beach in greater detail. 
Figure 13. Fort Myers Beach study area and beach and nearshore survey positions (red transects - May to October 2009; blue transects - April 2010 to May 2013).

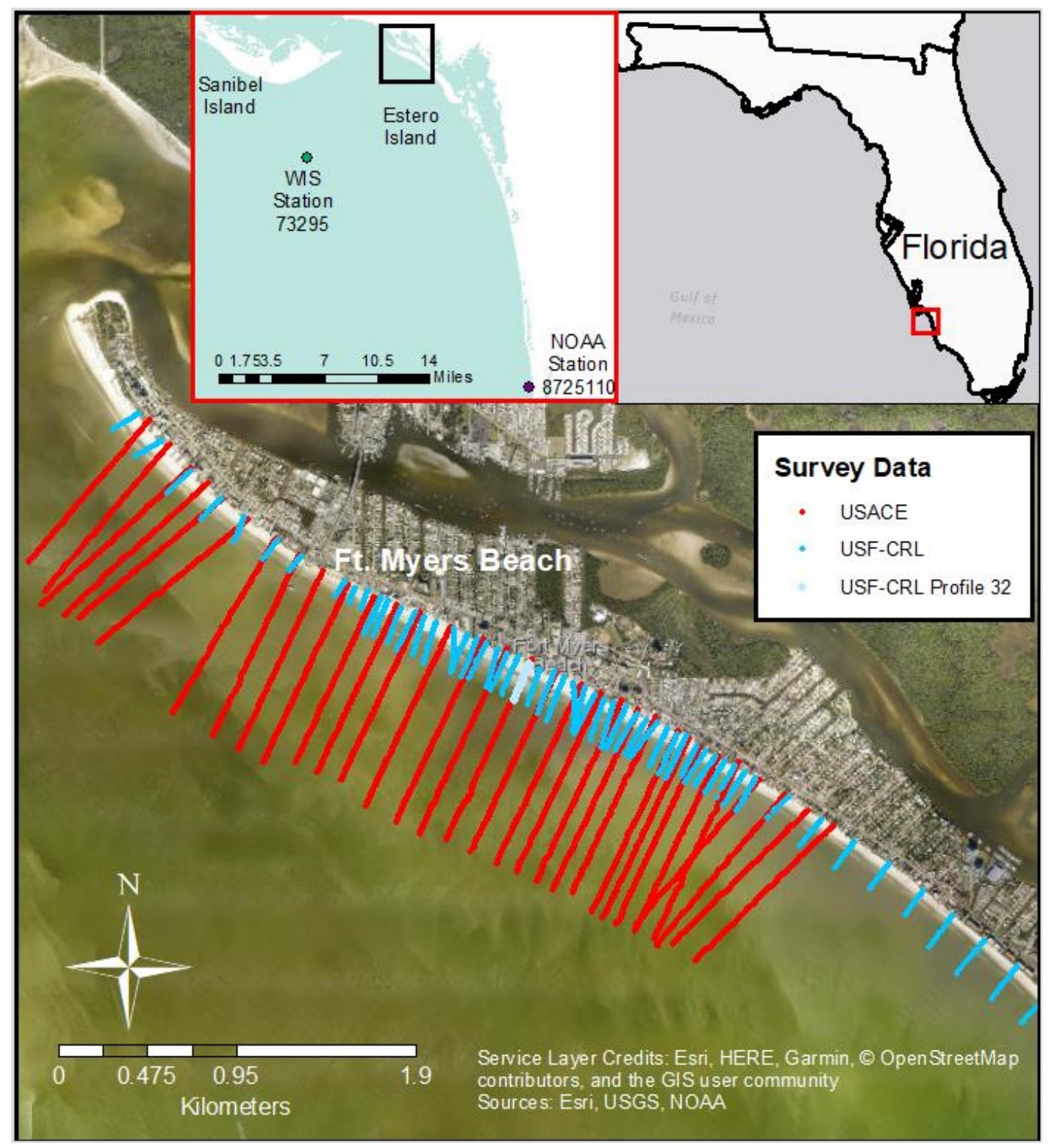

Tidal datum information from National Oceanic and Atmospheric Administration (NOAA) station 8725110 in the Gulf of Mexico, in Naples, $\mathrm{FL}$, was used to represent tidal conditions at the nearshore berm placement. NOAA station 8725110 is approximately 38 kilometers $(\mathrm{km})$ southeast of Fort Myers Beach (Figure 13). The mean tidal range at NOAA station 8725110 is approximately $0.61 \mathrm{~m}$. Surveys were georeferenced to NAVD88, which is $0.19 \mathrm{~m}$ above mean sea level at NOAA gage 8725110 . Mean high water (MHW) occurs at a NAVD88 elevation of $0.11 \mathrm{~m}$. Mean low water (MLW) occurs at a NAVD88 elevation of $-0.51 \mathrm{~m}$. 
Wave characteristics in the vicinity of the berm vary seasonally. Between October and April cold fronts impact the area with an approximate recurrence interval of 10 to 14 days. Relatively infrequent tropical storms and hurricanes may impact the area during summer months. Wave heights during conditions not impacted by cold fronts or tropical storms are typically low (0.1 to $0.3 \mathrm{~m}$ ) and generated by local winds. Sanibel Island shelters the northern end of Estero Island from waves from the northwest. Net alongshore sediment transport is generally to the southwest (Walton 1973; USACE 1969, 2001) but has been observed to the north on the northern $3 \mathrm{~km}$ of Estero Island (Balsillie and Clark 1992; USACE 1969, 2001) resulting from the sheltering effect of Sanibel Island.

A variety of alongshore sediment transport rates have been estimated on Estero Island, ranging up to 53,000 m3/year (USACE 1969, 2001; Walton 1973; Poff and Stephen 1998). The placement location of the nearshore berm was based on the approximate nodal point of longshore sediment transport direction reversal. For more information on the general hydrodynamic conditions near the Fort Myers Beach nearshore berm, please see Brutsché et al. (2014) and Wang et al. (2013). The specific WIS hindcast estimates of hydrodynamic conditions between surveys that are used in analyses within this technical report are presented in Chapter 5 .

\subsection{Nearshore berm monitoring}

The morphodynamics of the nearshore berm at Fort Myers Beach was measured through 10 surveys spanning the 4 years following construction (Figure 13). The USACE Jacksonville District performed a survey for the study area with 32 beach profile transects before construction began (May 2009) and after construction was completed (October 2009). Real Time Kinematic Global Positioning System (RTK GPS) topographic data were collected for locations shallower than $-1 \mathrm{~m}$, and synchronized precision echo sounder and RTK GPS data for locations deeper than -1 m, extending approximately $1 \mathrm{~km}$ offshore. The University of South Florida Coastal Research Lab (USF-CRL) conducted eight surveys of the study area approximately semi-annually over the 4 years following construction. USF-CRL surveys were conducted in April 2010, October 2010, June 2011, September 2011, March 2012, July 2012, September 2012, and May 2013. USF-CRL measurements included 57 transects, which were surveyed with an electronic total survey station and survey rod following standard leveland-transit procedures (Brutsché et al. 2014). USF-CRL survey lines were collected with uniform stationing and consistent locations every $50 \mathrm{~m}$ 
within the project area and every $100 \mathrm{~m}$ to $200 \mathrm{~m}$ within the control areas on either side of the project. Horizontal survey coordinates were georeferenced to State Plane Florida West (0902) and vertical survey coordinates were referenced to the NAVD88. Additional data were collected as part of the monitoring project at the Fort Myers Beach nearshore berm, but only elevation data were analyzed as a part of this technical report.

\subsection{Bathymetry raster}

Profile data collected at the nearshore berm at Fort Myers Beach were combined by collection date and interpolated onto triangular networks within the grid generation feature of the Surface Modeling System (SMS) 12. Triangular elements connected three measured data points, ideally between only two profiles. Outlying elements that connected three different profile lines were omitted to improve interpolated bathymetry fidelity. Triangular networks between measured elevations were interpolated onto a twodimensional horizontal mesh with finer resolution and more uniform spacing. Data from the interpolated mesh within SMS were exported to Matrix Laboratory (MATLAB) and interpolated onto a uniformly spaced grid using a Shephard (1968) inverse-distance-weighting scheme. The Shephard (1968) inverse-distance-weighting scheme is controlled by the shape factor $(\alpha)$ and search radius $(r)$ following the equations

$$
\begin{gathered}
w_{i}=\frac{1}{r_{i}^{\alpha}} \\
\widehat{Z}=\frac{\sum_{1}^{n} w_{i} \cdot z_{i}}{\sum_{1}^{n} w_{i}}
\end{gathered}
$$

where

$$
\begin{aligned}
r & =\text { search radius of points to include in inverse distance weighting } \\
\alpha & =\text { shape factor to specify impact of distance on weighting } \\
i & =1 \text { to the number of data points within search radius } r \\
r_{i} & =\text { horizontal distance from a data point to the interpolant point } \\
w_{i} & =\text { weighting factor of each point within search radius } r \\
Z_{i} & =\text { elevation data of each point within search radius } r \\
\hat{z} & =\text { inverse distance weighted elevation. }
\end{aligned}
$$


Search radii $(r)$ of $7.5 \mathrm{~m}$ and shape factors $(\alpha)$ of 2 were selected to convert the SMS interpolated bathymetry mesh to the inverse-distance-weighted uniform grid with cell dimensions of $5 \mathrm{~m}$ by $5 \mathrm{~m}$.

Two-dimensional grids of data were used within MATLAB for volume and elevation calculations. The horizontal areas described by profiles varied slightly between survey dates, creating the distinction between inclusive, exclusive, and extrapolated bathymetry sets. The bathymetry sets termed inclusive removed no valid data in any survey. The bathymetry sets termed exclusive only included data contained within horizontal area represented within every survey. Uniform grids of bathymetry were also generated from profiles extrapolated to a uniform distance offshore.

Comparisons between bathymetry profile sets before and immediately after nearshore berm construction indicate that USF-CRL profile measurements did not cover the entire offshore extent impacted by the berm placement. The exclusive bathymetry raster covered in each survey captured only approximately $64 \%$ of the initial berm volume whereas the raster of USACE survey data on the extrapolation grid captured approximately $98 \%$. Bathymetry profiles were extrapolated to create an elevation raster that covered the area impacted by the initial berm construction for each profile set date. Offshore slopes in elevation profiles indicate convergence with the pre-construction surveys. The extrapolation procedure extended each profile line to ensure elevations covering at least $275 \mathrm{~m}$ offshore of the preconstruction shoreline along each survey line. Trend lines were fit through the measured easting and northing positions of each profile line to determine the positions of each extrapolated point, which were uniformly spaced $5 \mathrm{~m}$ apart in the along-profile direction. Profiles collected by the USACE in May and October of 2009 appear to have covered the entire offshore extent of the nearshore berm placement (Figure 14). 
Figure 14. (a) interpolated 05/2009 pre-construction survey, (b) interpolated 10/2009 post-construction survey, (c) elevation difference between pre-construction and post-construction surveys

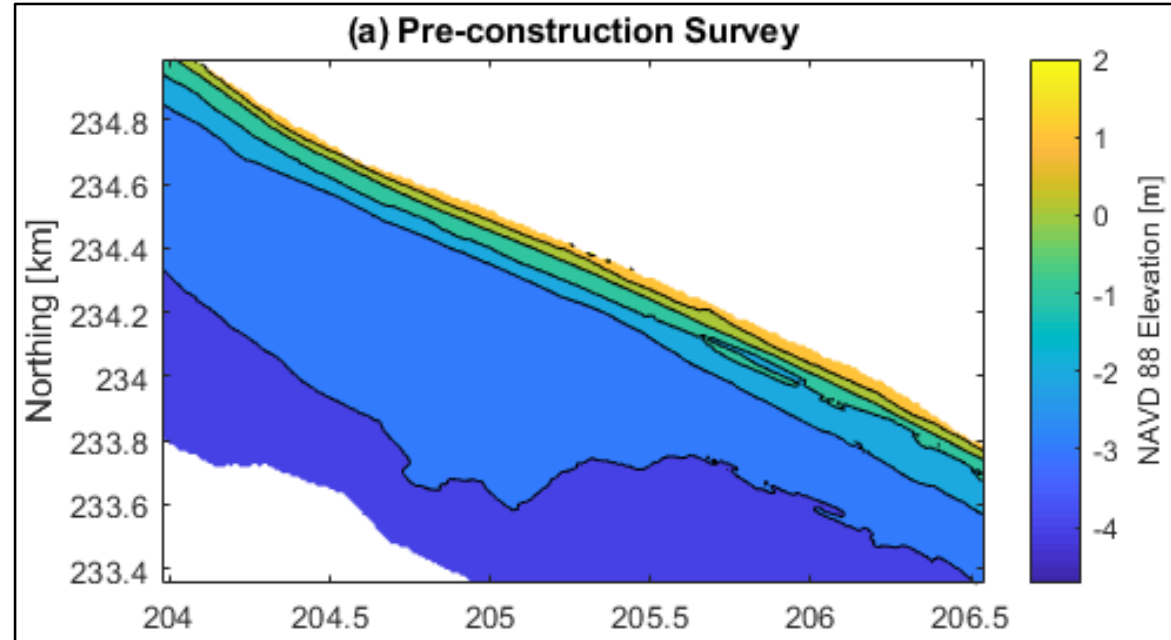

(b) Post-construction Survey

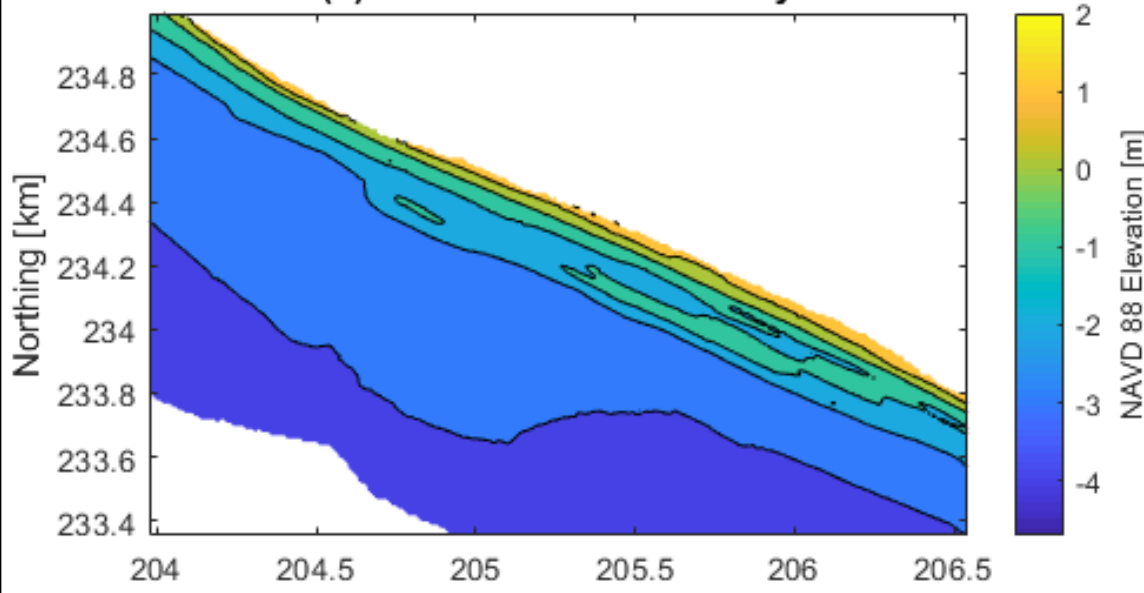

(c) Pre-construction to Post-construction Elevation Difference

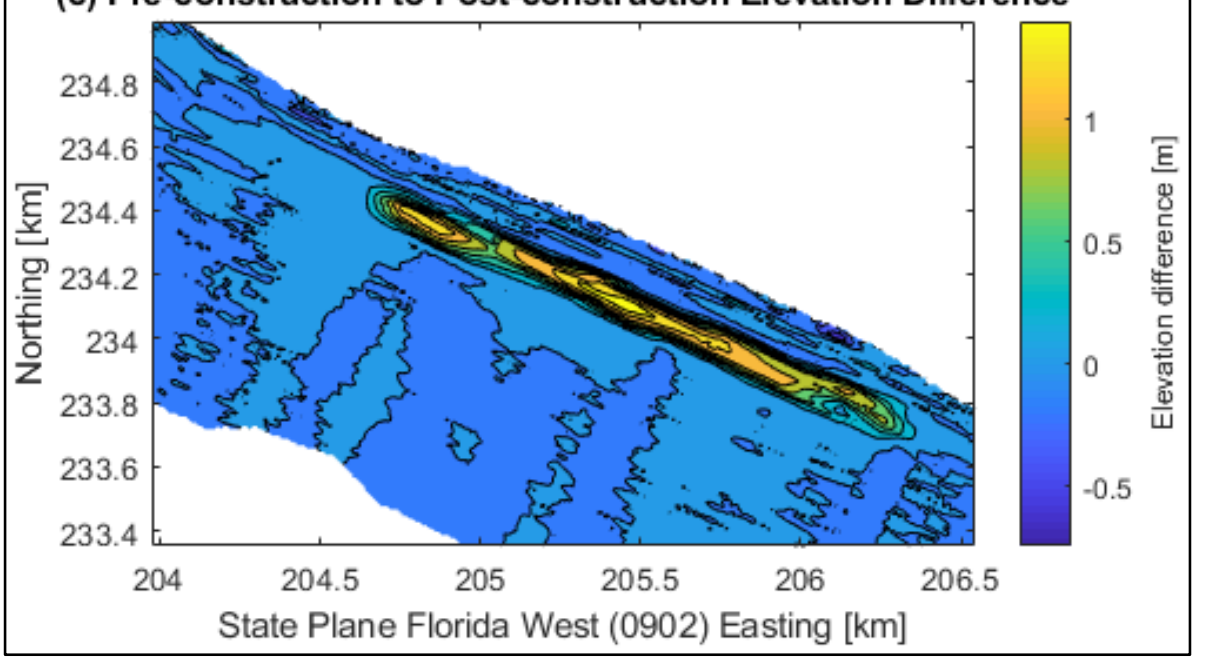


Pre-construction and immediately post-construction survey data are interpolated onto the extrapolated profile lines from subsequent dates. Elevation data at extrapolated points are computed from the minimum of the linear extrapolation of the mean slope of the four most offshore measurements on that profile line and the constant sloped line connecting the most offshore measurement with the most offshore extrapolation. Extrapolated bathymetries were assumed to be greater than or equal to the elevations measured prior to nearshore berm construction plus the difference observed at the most offshore point on that transect immediately after berm construction. A minimum extrapolated elevation value was computed from the pre-construction interpolated profile for each extrapolated position and added to the difference between the most offshore points in the interpolated pre-construction and post-construction surveys on the same profile line.

As an example, the USF-CRL profile line 32 collected in April 2010 extended approximately $180 \mathrm{~m}$ offshore (Figure 13, Figure 15). A trend line through the easting and northing data of each profile determined the horizontal coordinates of the extrapolated profile out to $275 \mathrm{~m}$ offshore of the pre-construction shoreline. Extrapolated bathymetry along USF-CRL profile 32 was specified as at least $0.08 \mathrm{~m}$ higher than the interpolation of the May 2009 pre-construction survey at the same position to match the first post-construction survey. The extrapolated elevations of USF-CRL data generally appear to be reasonable (Figure 15, Figure 16). Elevation differences between extrapolated post-construction bathymetry and the pre-construction survey indicate onshore migration with non-trivial timevarying alongshore elevation variability (Figure 17). Elevation differences for each survey between April 2010 and March 2012 indicate decreasing areas at peak elevation differences and decreasing elevation differences along the offshore edge of the nearshore berm. The May 2013 survey indicates a similar response. The July and September 2012 surveys captured storm-induced morphologic change after Tropical Storm Debby and Hurricane Isaac and indicate a steepened elevation difference crest, decreased elevation differences onshore of the nearshore berm, and the formation of a nearshore bar feature which extended the nearshore berm to the south. Qualitative elevation difference comparisons of the area around the nearshore berm may indicate that the nearshore berm moved onshore and flattened between all surveys other than the two with the largest storms (03/12 to 09/12) (Figure 17). 
Figure 15. Example USF-CRL profile 32 extrapolation to $275 \mathrm{~m}$ offshore of preconstruction shoreline.

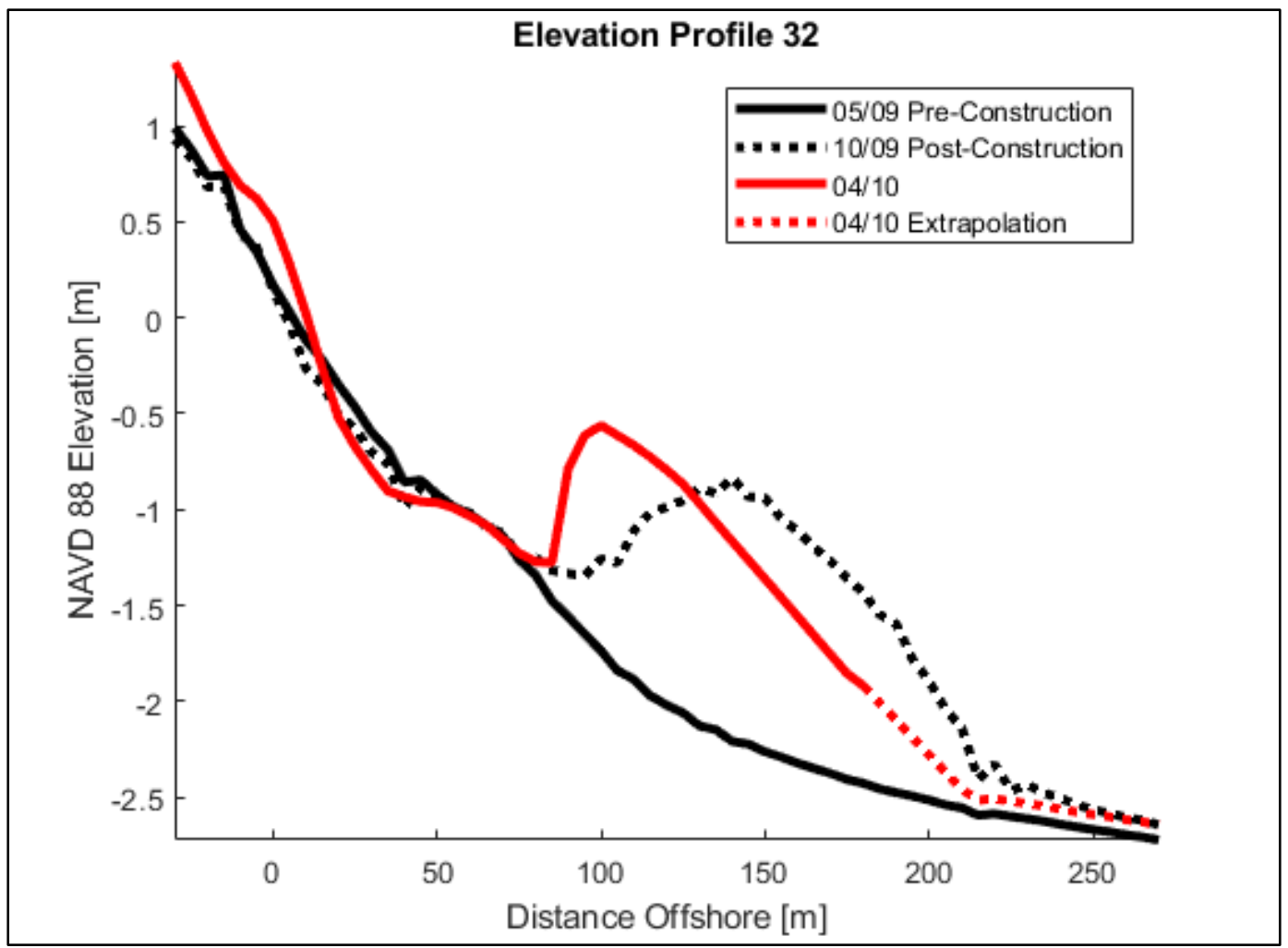

Figure 16. Elevation differences between extrapolated bathymetry data and preconstruction survey for each USF-CRL survey and respective cross-shore data extents.

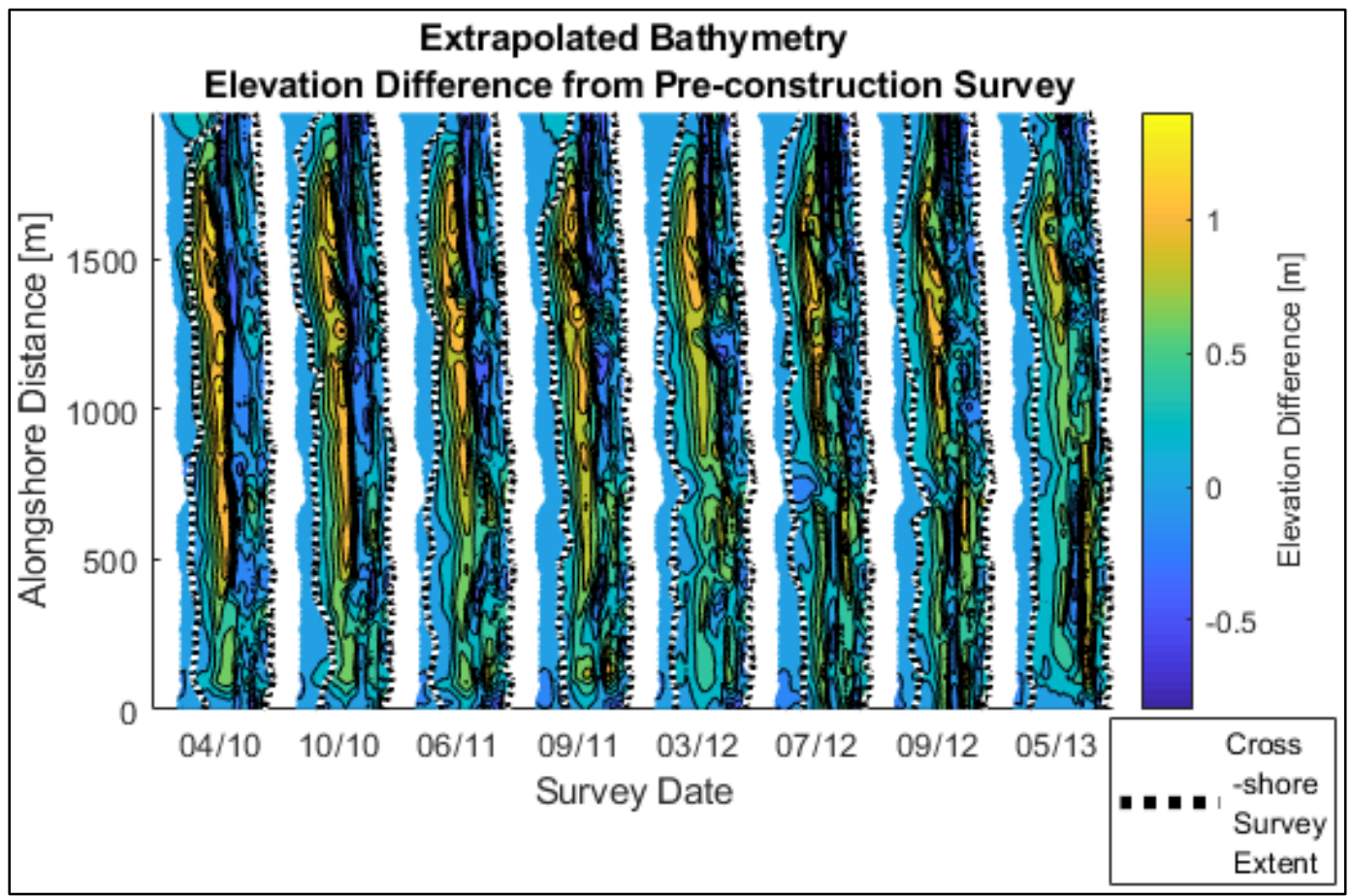


Figure 17. Elevation differences from the pre-construction survey for all surveys of the nearshore berm at Fort Myers Beach. Horizontal black lines indicate the same position across surveys. Dashed lines indicate shorelines (MSL).

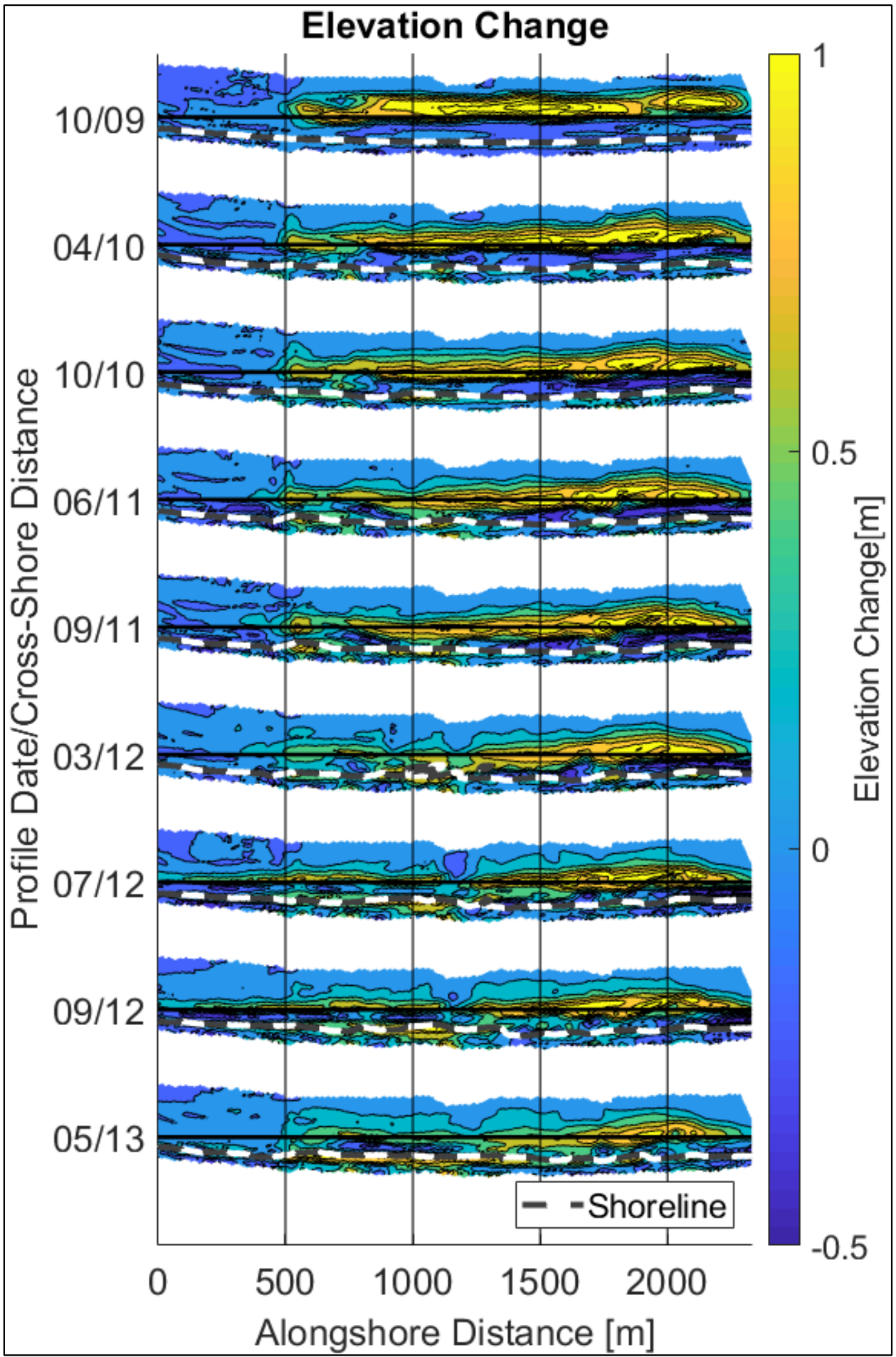




\subsection{Alongshore averaged elevation profiles}

Each uniformly gridded raster of extrapolated elevation data is averaged in the alongshore to represent the characteristic cross-shore elevation profile. Data measured at State Plane Florida West easting coordinates less than $204.7 \mathrm{~km}$ are omitted to exclude shoreline curvature at Matanzas Pass. Data are transformed onto a rotated horizontal grid at an angle of $114.4^{\circ}$ from north to represent a shore normal coordinate system in which the $x$-coordinate increases offshore. The cross-shore and alongshore directions are estimated as static throughout the domain to simplify volume calculations and alongshore averaging.

The term cross-shore used in this report is applied to the direction of the representative cross-shore axis and is not necessarily perpendicular to the local shoreline angle. While the imposed easting limits reduced shoreline curvature, residual curvature was evident in cropped rotated data. As a result of shoreline curvature and the coordinate simplification, a feature which is entirely uniform parallel to the shoreline may be smeared along a non-trivial cross-shore extent. Shoreline curvature and alongshore variability in the cropped rotated elevation data limit the usefulness of alongshore averaged elevations; however, they facilitate comparisons with cross-shore processes. Elevation data do contain substantial alongshore variability, which changes with time (Figure 19). Alongshore averaged elevation data do not represent changes in the alongshore well, but do represent the cross-shore component of morphology. The reduction in total alongshore elevation variability could reflect placed sediment diffusing in the alongshore (Figure 19) but was not investigated in detail. Additionally, gaps that were observed in the nearshore berm are not represented by an alongshore average. Distances offshore were referenced to the position of the nearest point to Mean Sea Level (MSL) on the averaged pre-construction elevation profile. The representation of the entire berm placement area in a single cross-shore elevation profile facilitates qualitative comparisons among all survey dates.

The changes in elevation concurrent with nearshore berm morphologic change may be described in three approximate cross-shore sections: the littoral zone, the foreshore, and the backshore. The extents covered by each of these zones are related to tidal datum information. The onshore edge of the littoral zone is defined as the MLW line (Figure 18). The offshore edge of the littoral zone was set to a limit of $210 \mathrm{~m}$ offshore based on data availability. While elevation profile data were extrapolated to $275 \mathrm{~m}$, 
bathymetry raster formation procedures and shoreline curvature resulted in some cross-shore elevation transects with only $210 \mathrm{~m}$ of data offshore of the alongshore averaged shoreline. The edges of the foreshore were defined by the MLW and MHW lines (Figure 18). For this application the backshore is defined as the region above MHW. Alongshore averaged elevation profiles indicate that dredge material was predominantly placed in the littoral zone (Figure 18). In the majority of surveys, alongshore averaged elevation profile local maxima and inflection points occurred in the littoral zone (Figure 18). Observed morphologic change in the backshore was considered to be more chaotic than morphologic change at other cross-shore positions. While some patterns of elevation change may be observed above MHW, morphology and morphologic change in the backshore is not discussed in detail in this technical report.

Trends indicated by alongshore-averaged elevations do not reflect substantial elements of the morphologic change but do reflect the crossshore component of observed morphology. Alongshore averaged crossshore elevation profiles indicate that the nearshore berm moved onshore and diffused between October 2009 and March 2012 (timespans 1 through 5) (Figure 18). Profile data show nearshore berm movement offshore between March 2012 and September 2012 (timespans 6 and 7) concurrent with the two largest storm events during the study. Following the large storms, the nearshore berm appears to have moved onshore and flattened between September 2012 and May 2013 (timespan 8). From October 2009 to March 2012 and September 2012 to May 2013 (timespans 1 through 5 , and 8) the elevation differences from the preconstruction surveys became progressively more uniformly distributed across the entire cross-shore profile. The nearshore berm crest moved onshore, the area onshore of the nearshore berm gained sediment, and profile slopes generally decreased between all surveys other than July and September 2012 (timespans 6 and 7). 
Figure 18. Mean cross-shore elevation profile.

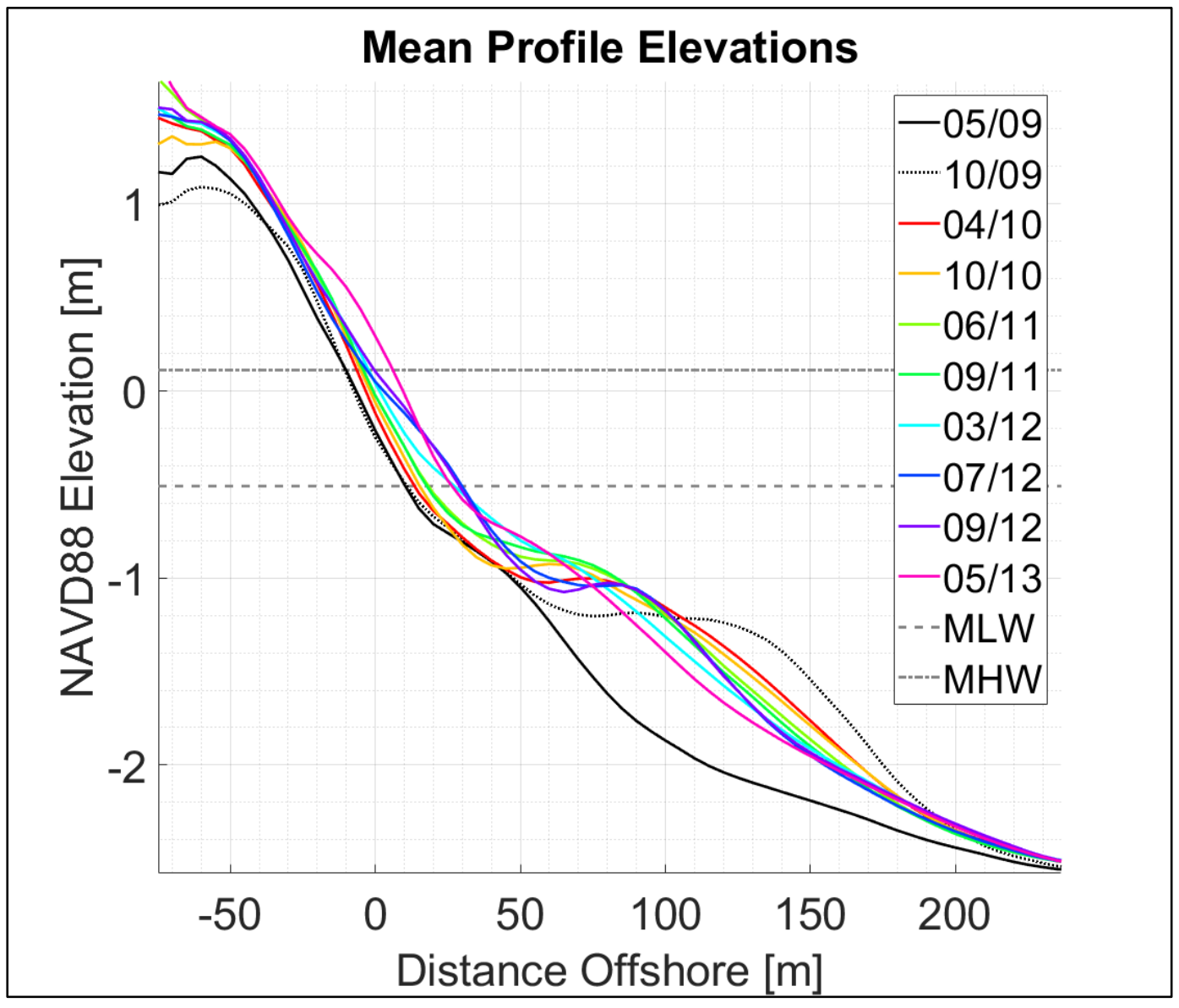


Figure 19. Littoral zone elevation alongshore standard deviation.

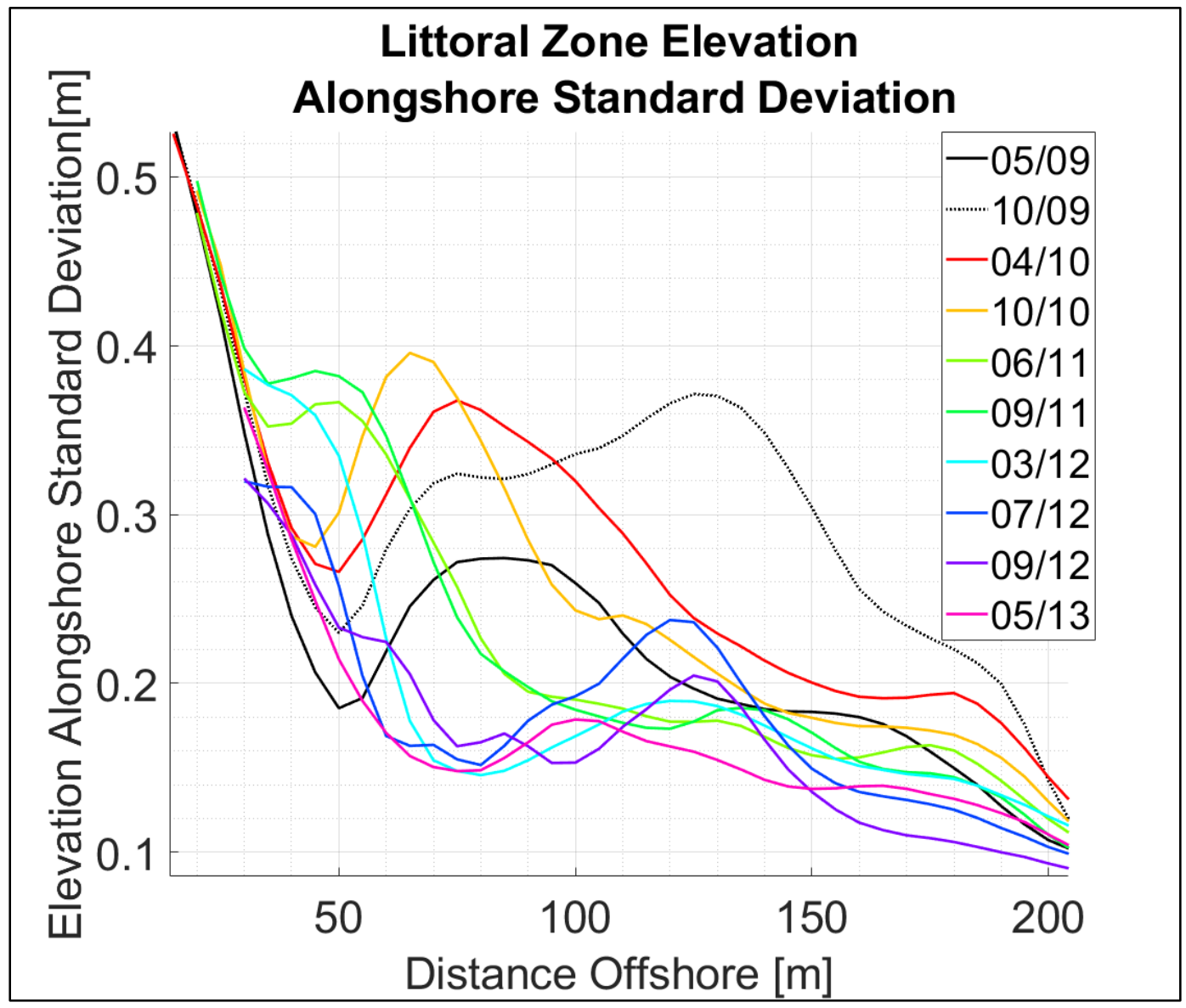

Nearshore berm evolution was also evaluated with alongshore averaged cross-shore profiles of elevation difference. Elevation differences for each point were determined by subtracting the elevations in the preconstruction survey from the elevations in each subsequent survey. An elevation difference value of zero indicates the same elevation as the preconstruction survey at that position. Positive elevation differences indicate local accretion or elevation gain. Alongshore averaged cross-shore profiles of elevation difference represent the difference between each cross-shore position in the alongshore averaged pre-construction profile and alongshore averaged profiles from subsequent surveys.

All alongshore averaged elevation difference profiles indicated a generally parabolic shape in the littoral zone, which is interpreted here as a representation of the position of the nearshore berm (Figure 20). Other than the July and September 2012 data (timespans 6 and 7), the peak of the parabolic alongshore averaged elevation difference shape in the littoral zone decreased, moved onshore, or decreased and moved onshore between 
all surveys (Figure 20). Littoral zone alongshore averaged elevation difference peaks increased and moved offshore between March and September 2012 (timespans 6 and 7). A distinct alongshore averaged elevation difference peak also formed within the foreshore between March and July 2012 (timespan 6). The alongshore averaged foreshore elevation difference peak moved onshore and increased between September 2012 and May 2013 (timespan 8). The peak of the littoral zone parabolic alongshore averaged elevation difference shape which increased and moved offshore between March and July 2012 (timespan 6) decreased substantially and moved onshore between September 2012 and May 2013 (timespan 8). Littoral zone alongshore-averaged elevation differences indicate a pattern of onshore migration and nearshore berm diffusion between nearshore berm responses from October 2009 to March 2012 (timespans 1 to 5) and September 2012 to May 2013 (timespan 8), but substantial alongshore variability could indicate additional morphologic responses, such as alongshore diffusion, as well.

Figure 20. Littoral zone and foreshore mean cross-shore elevation profile difference from pre-construction survey.

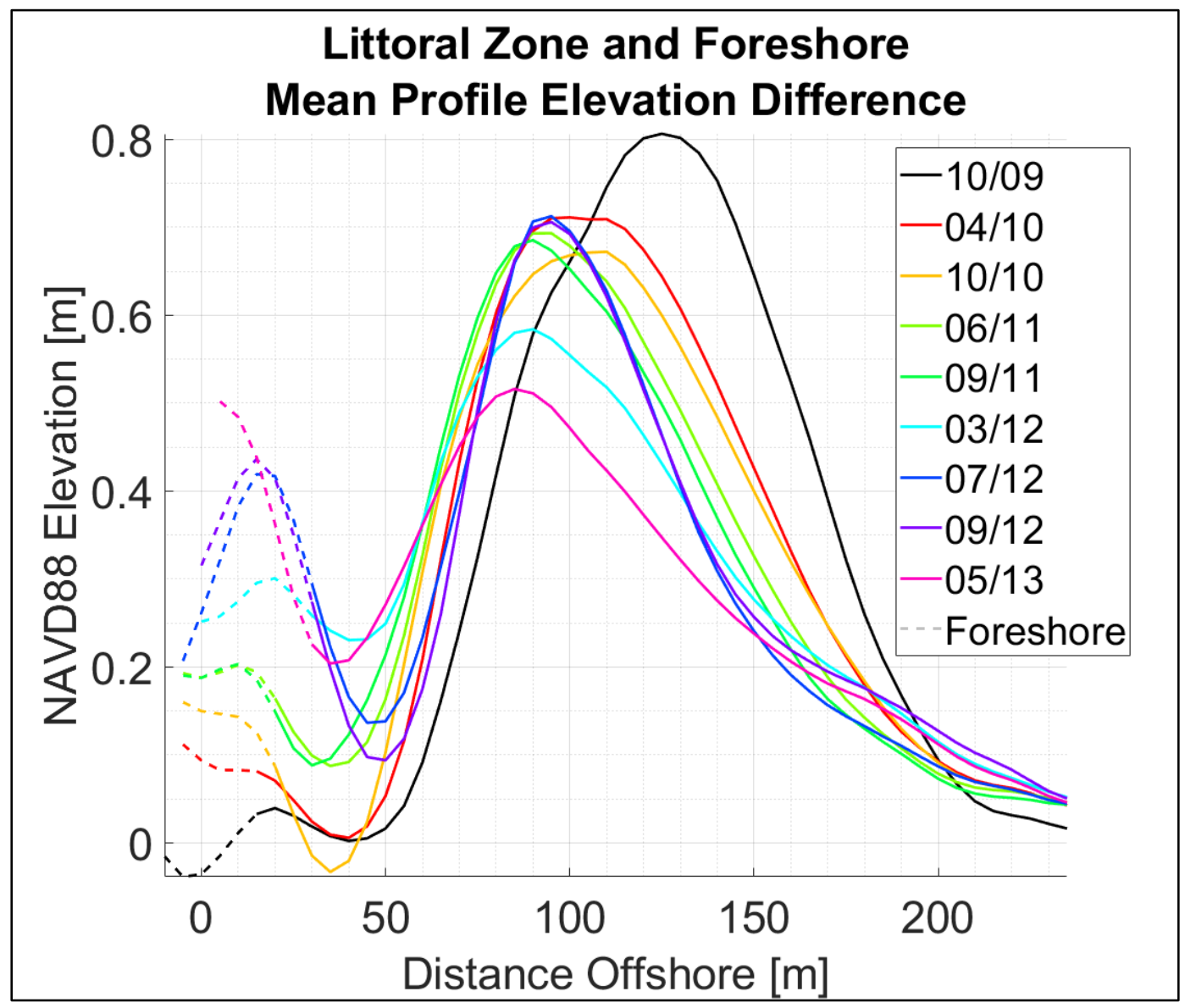


Nearshore berm morphologic change may also be analyzed through changes between surveys. Bathymetry changes between surveys were addressed by subtracting the previous survey elevation at each point of each alongshore averaged cross-shore elevation profiles (Figure 21, Figure 22). In the littoral zone, alongshore averaged elevations between October 2009 and September 2011 (timespans 1 to 4) increased most substantially landward of an area of elevation decrease. The cross-shore patterns of elevation loss and gain at the nearshore berm between October 2009 and September 2011 (timespans 1 to 4) correspond to migration onshore. Changes in alongshore averaged nearshore berm elevation between September 2011 and March 2012 (timespan 5) followed a similar pattern to previous alongshore averaged elevation changes; however, the location of peak elevation change moved into the foreshore.

The dominant area of alongshore averaged elevation decrease in the littoral zone between March and July 2012 (timespan 6) was onshore of the dominant area of elevation gain, corresponding to nearshore berm migration offshore. Differences between alongshore averaged elevation profiles followed a similar pattern at the nearshore berm between July and November 2012 (timespan 7) with lesser elevation gains which were farther offshore. Littoral zone alongshore averaged elevation change between September 2012 and May 2013 (timespan 8) followed a similar pattern to the elevation changes between October 2009 and September 2011 (timespans 1 through 4) with an area of major elevation gain onshore of an area of major elevation loss, corresponding to onshore migration. 
Figure 21. Mean profile elevation change between surveys.

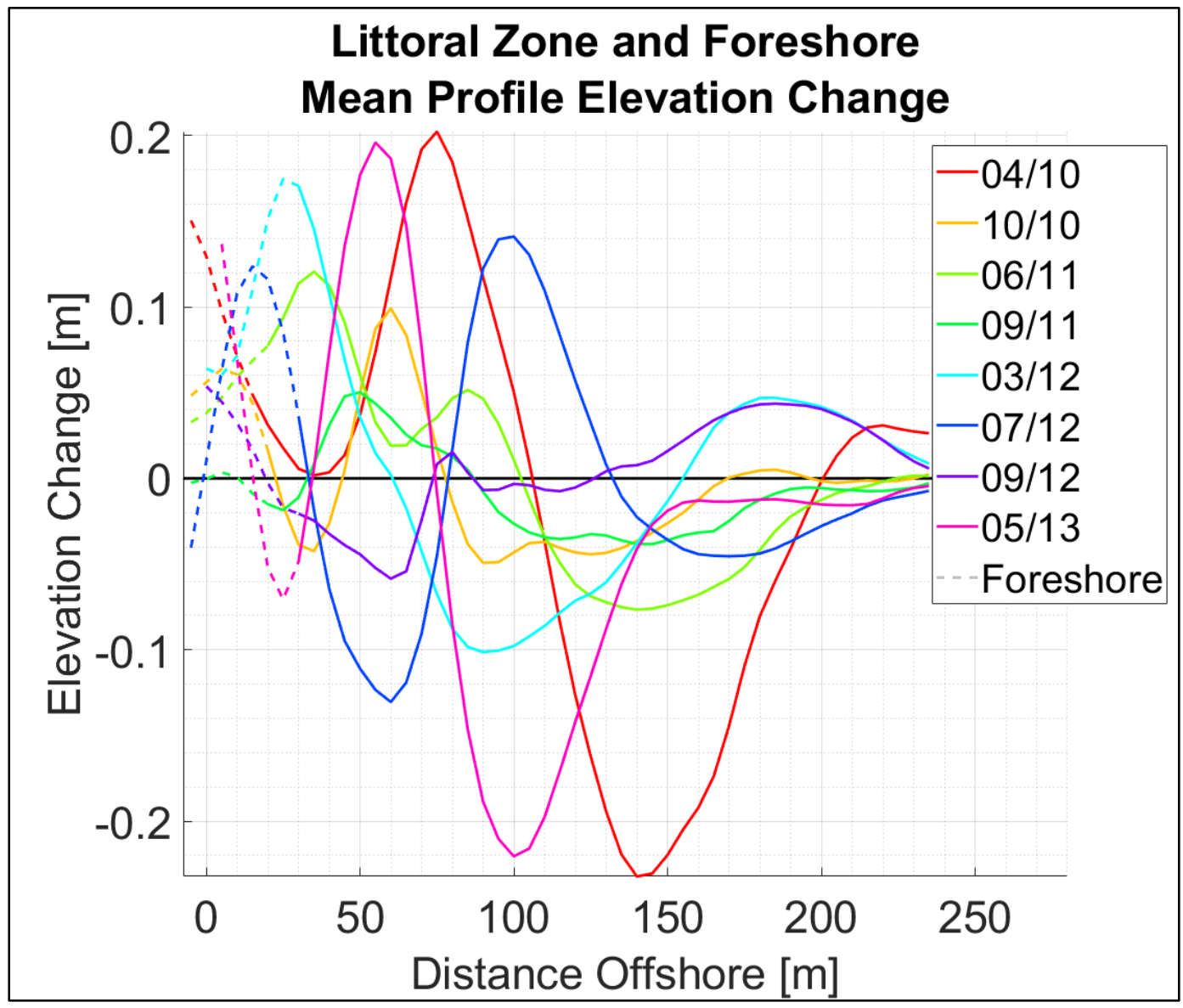


Figure 22. Mean profile elevation change between surveys relative to profile volume.

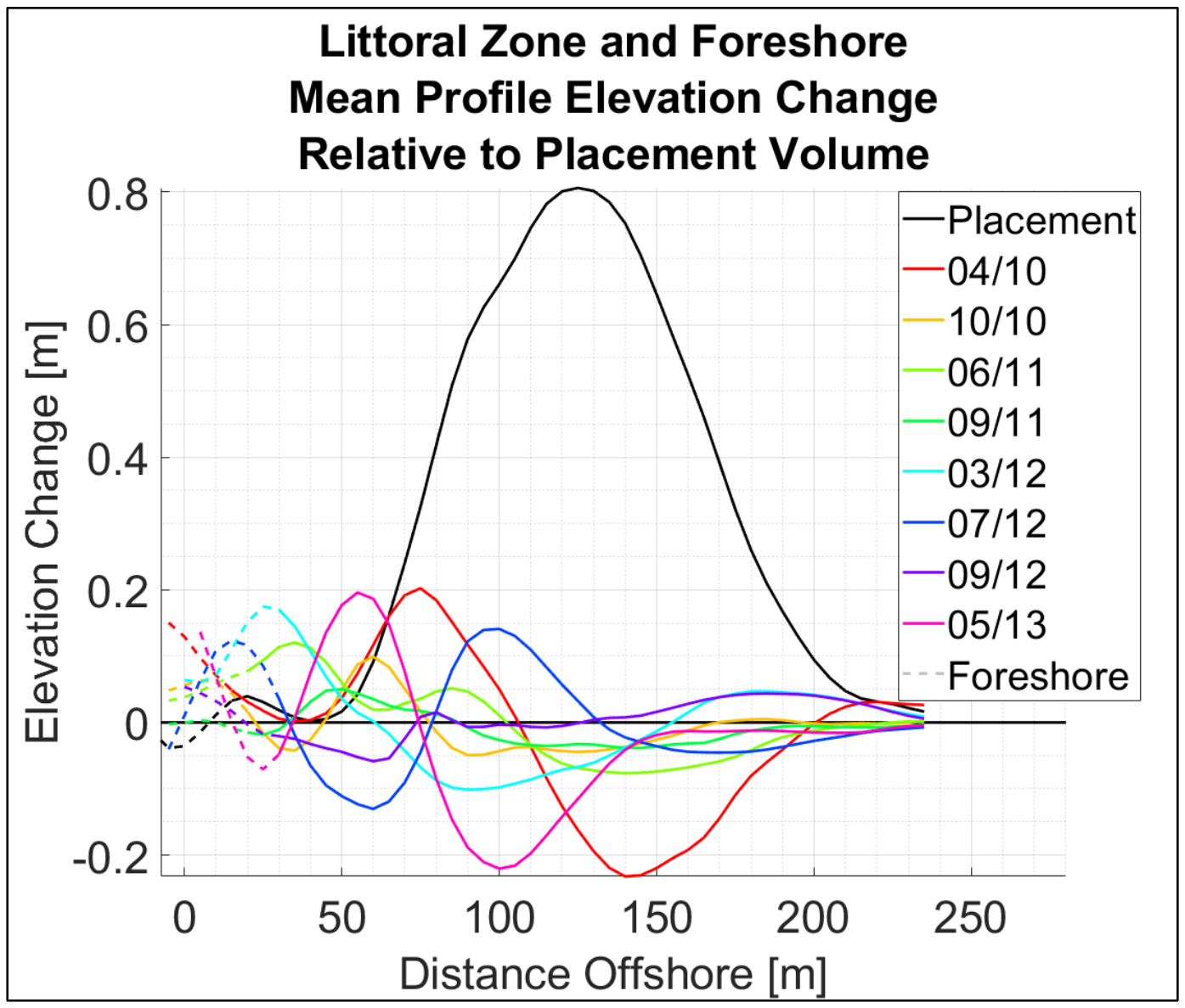

Alongshore averaged elevation profile data indicate that the nearshore berm migrated onshore and smoothed out between all surveys other than July and September 2012 (timespans 6 and 7). Onshore migration appears to have been generally concurrent with a decrease in nearshore berm protrusion from the pre-construction profile outside of the foreshore. The nearshore berm appears to have steepened and migrated offshore between March and September 2012 (timespans 6 and 7), coinciding with most energetic storms during the study. 


\section{Case Study Waves and Nearshore Berm Morphodynamics}

Hydrodynamics were estimated at the Fort Myers Beach nearshore berm placement and compared with observed nearshore berm responses. A variety of wave and empirical berm metrics were compared to a variety of quantifications of nearshore berm morphodynamics to investigate the applicability of each wave characteristic combination to nearshore berm morphodynamics. Correlations connecting any morphodynamic trait of a nearshore berm to commonly available local wave climate information could be particularly useful for scoping level estimates of nearshore berm morphodynamics.

The skill of various combinations of wave characteristics at describing the evolution of a variety of nearshore berms is generally not well understood, which limits the ability to describe a set of wave characteristics as representative for nearshore berm morphologic change. Correlations between the substantial majority of wave characteristic and nearshore berm response pairs were not robust, but two relationships that describe nearshore berm morphodynamics with some success were found.

Section 5.2 discusses the relationship between nearshore berm cross-shore migration direction and several wave characteristics. Section 5.3 discusses the relationship between sediment transport at a nearshore berm and wave energy flux, as well as the substantial associated caveats.

\subsection{Hydrodynamics during Fort Myers Beach nearshore berm lifespan}

Hydrodynamics at the nearshore berm at Fort Myers Beach, FL, were estimated by transforming WIS wave hindcast information from the nearest point. WIS station 73295 is $14.7 \mathrm{~km}$ southwest of the placement in a mean water depth of $5 \mathrm{~m}$. Wave information between the nine postconstruction surveys were separated into eight timespans, the beginnings and ends of which were specified by survey dates. Wave transformations to the nearshore berm followed the procedure established in Chapter 3.1.1, which did not transform the time of occurrence; however, the travel time between the WIS station and the nearshore berm was considered to be small relative to the time between surveys. Waves were transformed to the lesser value of the breaking depth and nearshore berm depth of the alongshore averaged cross-shore transect of elevation from the previous 
survey. Berm depth varied between approximately $1.15 \mathrm{~m}$ and $0.86 \mathrm{~m}$ over the duration of the study.

The mean significant wave height in timespan 1 (red) between October 2009 and April 2010 was greater than in any other timespan (Figure 23, Table 1). Mean significant wave heights in timespans 2 (orange) and 4 (green) were less than in any other timespan. Timespan 2 lasted from April to October 2010, and timespan 4 lasted from June to September of 2011; neither of which included any winter data. Timespans 3 (light green), 5 (cyan), and 8 (magenta) covered similar times of year and contained similar significant wave height averages. Timespan 3 lasted from October 2010 to June 2011, timespan 5 lasted from September 2011 to March 2012, and timespan 8 lasted from September 2012 to May 2013. Timespans 3, 5, and 8 contained substantial durations of winter data. Mean significant wave heights in timespans 6 (blue) and 7 (purple) were typical. Timespan 6 lasted from March to July 2012 and timespan 7 lasted from July to September 2012. Both timespan 6 and 7 contained almost entirely spring and summer data; however. both contained large storms. Tropical Storm Debby impacted the study area for approximately 4 days in June of 2012 during timespan 6. Hurricane Isaac impacted the study area for approximately 2 days in August 2012 during timespan 7. Both Tropical Storm Debby and Hurricane Isaac are considered to have dominated the wave impact on the observed nearshore berm morphodynamics (Brutsché et al. 2014). Mean significant wave heights suggest a low- to mediumenergy wave environment. Generally, mean significant wave height does not appear proportional to any observed morphodynamic aspects of this nearshore berm. 
Figure 23. Estimated significant wave height, peak period, cosine of wave angle, and wave energy flux between survey dates. Wave characteristics were transformed from WIS station 73295 to depth-induced breaking.

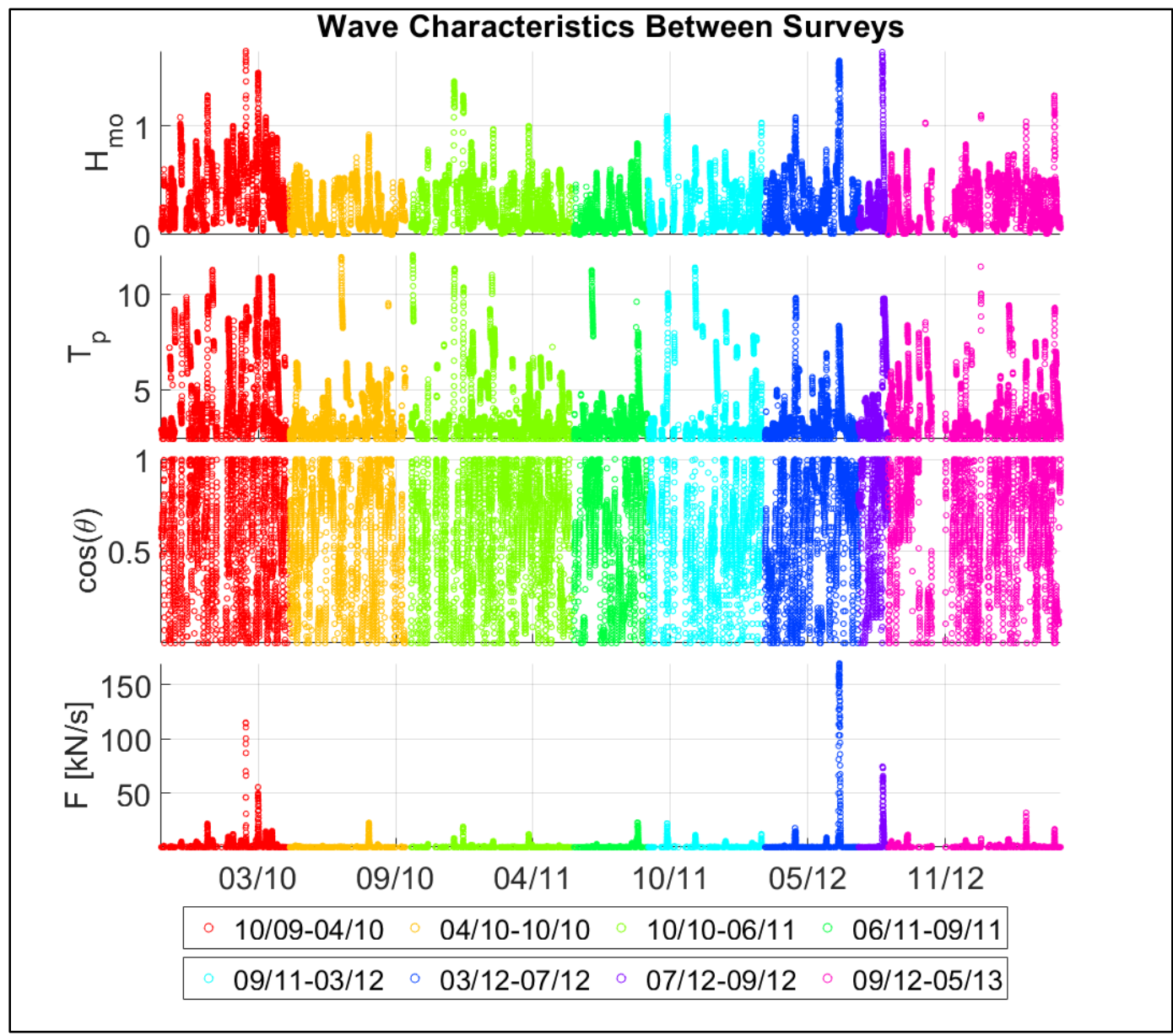

Variations in mean wave parameters between surveys were typically smaller than corresponding standard deviations. Significant wave height standard deviations were large relative to mean values in all timespans and were nearly equal to or greater than mean values in timespans 2, 3, 4, 5,6 , and 7. Large waves skewed averages such that the mean significant wave height was greater than or equal to the one-third significant wave height exceedance level in timespans 2, 3, 4, and 7 (Table 2). Mean wave angle varied by $25^{\circ}$ between surveys with standard deviations at least two times greater. 
Table 1. WIS station 73295 wave climate data between nearshore berm surveys.

\begin{tabular}{|c|c|c|c|c|c|c|c|c|}
\hline $\begin{array}{l}\text { Timespan } \\
\text { Number of } \\
\text { Wave Data }\end{array}$ & $\begin{array}{c}\text { Time } \\
\text { between } \\
\text { Surveys }\end{array}$ & $\begin{array}{c}\text { Mean } \\
H_{m o}[\mathrm{~m}]\end{array}$ & $\begin{array}{c}\text { Standard } \\
\text { Deviation } \\
H_{m o}[\mathrm{~m}]\end{array}$ & $\begin{array}{c}\text { Top } 3^{\text {rd }} \\
H_{m o}[\mathrm{~m}]\end{array}$ & $\begin{array}{c}\text { Mean } \\
T_{p}[\mathrm{~s}]\end{array}$ & $\begin{array}{c}\text { Standard } \\
\text { Deviation } \\
T_{p}[\mathrm{~s}]\end{array}$ & $\begin{array}{c}\text { Mean } \theta \\
{\left[^{\circ}\right]^{-}} \\
\text {(Shore } \\
\text { Normal) }\end{array}$ & $\begin{array}{c}\text { Standard } \\
\text { Deviation } \\
\theta\left[^{\circ}\right]\end{array}$ \\
\hline 1 & $\begin{array}{l}10 / 09- \\
04 / 10\end{array}$ & 0.40 & 0.29 & 0.50 & 4.6 & 2.2 & 356 & 60 \\
\hline 2 & $\begin{array}{l}04 / 10- \\
10 / 10\end{array}$ & 0.18 & 0.18 & 0.18 & 3.5 & 1.3 & 8 & 54 \\
\hline 3 & $\begin{array}{l}10 / 10- \\
06 / 11\end{array}$ & 0.23 & 0.22 & 0.23 & 3.6 & 1.6 & 6 & 56 \\
\hline 4 & $\begin{array}{l}06 / 11- \\
09 / 11\end{array}$ & 0.18 & 0.17 & 0.16 & 3.4 & 1.3 & 356 & 57 \\
\hline 5 & $\begin{array}{l}09 / 11- \\
03 / 12\end{array}$ & 0.24 & 0.23 & 0.27 & 3.6 & 1.8 & 20 & 54 \\
\hline 6 & $\begin{array}{l}03 / 12- \\
07 / 12\end{array}$ & 0.27 & 0.29 & 0.29 & 3.4 & 1.2 & 18 & 53 \\
\hline 7 & $\begin{array}{l}07 / 12- \\
09 / 12\end{array}$ & 0.22 & 0.28 & 0.16 & 4.0 & 2.0 & 355 & 53 \\
\hline 8 & $\begin{array}{l}09 / 12- \\
05 / 13\end{array}$ & 0.26 & 0.20 & 0.35 & 3.7 & 1.4 & 11 & 54 \\
\hline
\end{tabular}

Dean Numbers, mobility numbers from linear wave theory shear stress, mobility numbers from stream-function nonlinear wave theory near-bed velocity, migration coefficients (Douglass 1995), and cumulative transport rates (Hwung et al. 2010) were computed at the Fort Myers Beach nearshore berm for each timespan (Figure 24). Several of the empirical metrics used to investigate wave impact on berm morphodynamics depend on estimated or assumed site information, but the impact of associated uncertainties was assumed not to vary substantially between surveys. Representative grain diameter, fall velocity, underlying current velocity, water temperature, salinity, and critical shear stress were assumed to be constant throughout the nearshore berm lifespan so uncertainty errors are assumed to impact each estimate evenly between survey dates. 
Figure 24. Dean Number, mobility index, migration coefficient, and cumulative transport rate estimates between surveys Wave characteristics were transformed from WIS station 73295 to depth-induced breaking.

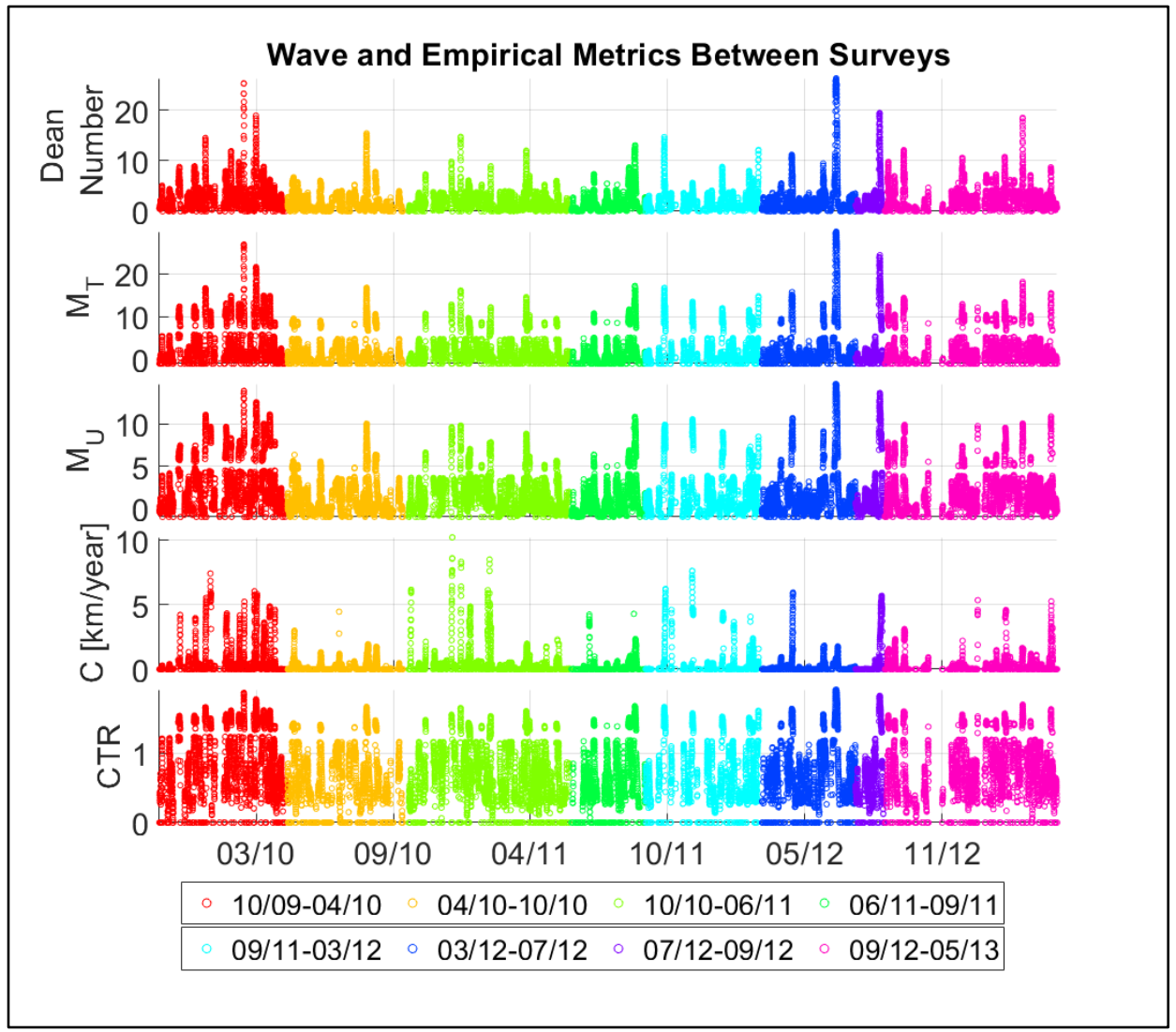

Table 2. WIS station 73295 empirical sediment transport and empirical bar morphodynamic metrics between nearshore berm surveys transformed to depthinduced breaking.

\begin{tabular}{|c|c|c|c|c|c|c|c|}
\hline $\begin{array}{c}\text { Timespan } \\
\text { Number } \\
\text { of Wave } \\
\text { Data }\end{array}$ & $\begin{array}{c}\text { Time } \\
\text { between } \\
\text { Surveys }\end{array}$ & $\begin{array}{c}\text { Dean } \\
\text { Number }\end{array}$ & $\begin{array}{c}\text { Linear } \\
\text { Wave } \\
\text { Theory } \\
\text { Mobility } \\
\text { Number }\end{array}$ & $\begin{array}{c}\text { Nonlinear } \\
\text { Wave } \\
\text { Theory } \\
\text { Mobility } \\
\text { Number }\end{array}$ & $\begin{array}{c}\text { Migration } \\
\text { Rate }\end{array}$ & $\begin{array}{c}\text { Cumulative } \\
\text { Transport } \\
\text { Rate }\end{array}$ & $\begin{array}{c}\text { Wave } \\
\text { Energy } \\
\text { Flux }\end{array}$ \\
\hline $\begin{array}{c}\text { Timespan } \\
\text { Number }\end{array}$ & Timespan & Dean [-] & $M_{T}[-]$ & Mu $[-]$ & $\begin{array}{c}\text { C [km } \cdot \mathrm{yr}^{-} \\
1]\end{array}$ & CTR [-] & $\begin{array}{c}\mathrm{F} \\
{\left[\mathrm{kWm}^{-}\right.} \\
1]\end{array}$ \\
\hline 1 & $\begin{array}{c}10 / 09- \\
04 / 10\end{array}$ & 2.79 & 3.28 & 2.77 & 0.582 & 0.752 & 1.92 \\
\hline 2 & $\begin{array}{c}04 / 10- \\
10 / 10\end{array}$ & 1.55 & 1.10 & 0.99 & 0.155 & 0.460 & 0.29 \\
\hline 3 & $\begin{array}{c}10 / 10- \\
06 / 11\end{array}$ & 1.62 & 1.35 & 1.37 & 0.309 & 0.552 & 0.28 \\
\hline
\end{tabular}




\begin{tabular}{|c|c|c|c|c|c|c|c|}
\hline $\begin{array}{c}\text { Timespan } \\
\text { Number } \\
\text { of Wave } \\
\text { Data }\end{array}$ & $\begin{array}{c}\text { Time } \\
\text { between } \\
\text { Surveys }\end{array}$ & $\begin{array}{c}\text { Dean } \\
\text { Number }\end{array}$ & $\begin{array}{l}\text { Linear } \\
\text { Wave } \\
\text { Theory } \\
\text { Mobility } \\
\text { Number }\end{array}$ & $\begin{array}{l}\text { Nonlinear } \\
\text { Wave } \\
\text { Theory } \\
\text { Mobility } \\
\text { Number }\end{array}$ & $\begin{array}{l}\text { Migration } \\
\text { Rate }\end{array}$ & $\begin{array}{c}\text { Cumulative } \\
\text { Transport } \\
\text { Rate }\end{array}$ & $\begin{array}{l}\text { Wave } \\
\text { Energy } \\
\text { Flux }\end{array}$ \\
\hline 4 & $\begin{array}{l}06 / 11- \\
09 / 11\end{array}$ & 1.55 & 0.99 & 0.91 & 0.147 & 0.426 & 0.44 \\
\hline 5 & $\begin{array}{l}09 / 11- \\
03 / 12\end{array}$ & 1.81 & 1.71 & 1.53 & 0.394 & 0.554 & 0.63 \\
\hline 6 & $\begin{array}{l}03 / 12- \\
07 / 12\end{array}$ & 2.17 & 1.95 & 1.50 & 0.149 & 0.551 & 3.57 \\
\hline 7 & $\begin{array}{l}07 / 12- \\
09 / 12\end{array}$ & 1.83 & 1.66 & 1.45 & 0.403 & 0.483 & 2.37 \\
\hline 8 & $\begin{array}{l}09 / 12- \\
05 / 13\end{array}$ & 2.08 & 1.86 & 1.67 & 0.232 & 0.611 & 0.60 \\
\hline
\end{tabular}

\subsection{Storms, Dean Number, wave energy flux, and migration direction}

Nearshore berms and sandbars are normally expected to move offshore during particularly large storms and onshore during calmer conditions. A large number of bar transects at Duck, NC, were compared in Larson and Kraus (1992), and a relationship between bar migration direction and the Dean Number limit of 7.2 was observed. Larson and Kraus (1992) observed sandbars moving onshore under conditions with Dean Numbers less than 7.2 and migrating offshore under conditions with Dean Numbers greater than 7.2.

The relationship between nearshore berm migration direction and Dean Number is investigated in this technical report for the 2009 nearshore placement at Fort Myers Beach. Times during which Dean Numbers were estimated to be greater than 7.2 were selected to represent storms and concurrent wave properties and empirical berm metrics were calculated to represent storm conditions (Figure 25, Figure 26). Wave characteristics and empirical berm metrics corresponding to Dean Numbers less than 7.2 represent non-storm conditions. Nearshore berm migration in timespans 1 through 5 and 8 was onshore and was considered to match expectations for non-storm nearshore berm response. Nearshore berm migration in timespans 6 and 7 was offshore and was considered to match expectations for storm nearshore berm response. Nearshore berm cross-shore migration direction was determined from alongshore averaged elevation profiles which do not capture the substantial alongshore elevation 
variability but do reflect changes in the cross-shore position of the nearshore placement centroid (Chapter 3.2.2).

Each timespan contained Dean Numbers greater than 7.2; however, only the surveys at the end of timespans 6 and 7 indicate nearshore berm migration offshore. The survey data available do not permit statements on the specific impact of each individual storm event; however, statements on the net change induced by both storm and non-storm conditions can be made. Comparisons of storm and non-storm wave and empirical nearshore berm morphodynamic metrics at the point of depth-induced breaking indicate that wave energy flux changes the most during storm conditions (Figure 25, Figure 26). Dean Numbers exceeding 7.2 coincided with wave energy flux peaks more closely with than the peaks of any other metric considered (Figure 25).

Figure 25. Dean Number, mobility index, wave energy flux, migration coefficient, and cumulative transport rate estimates between Fort Myers beach surveys. Wave characteristics were transformed from WIS station 73295 to depth-induced breaking.

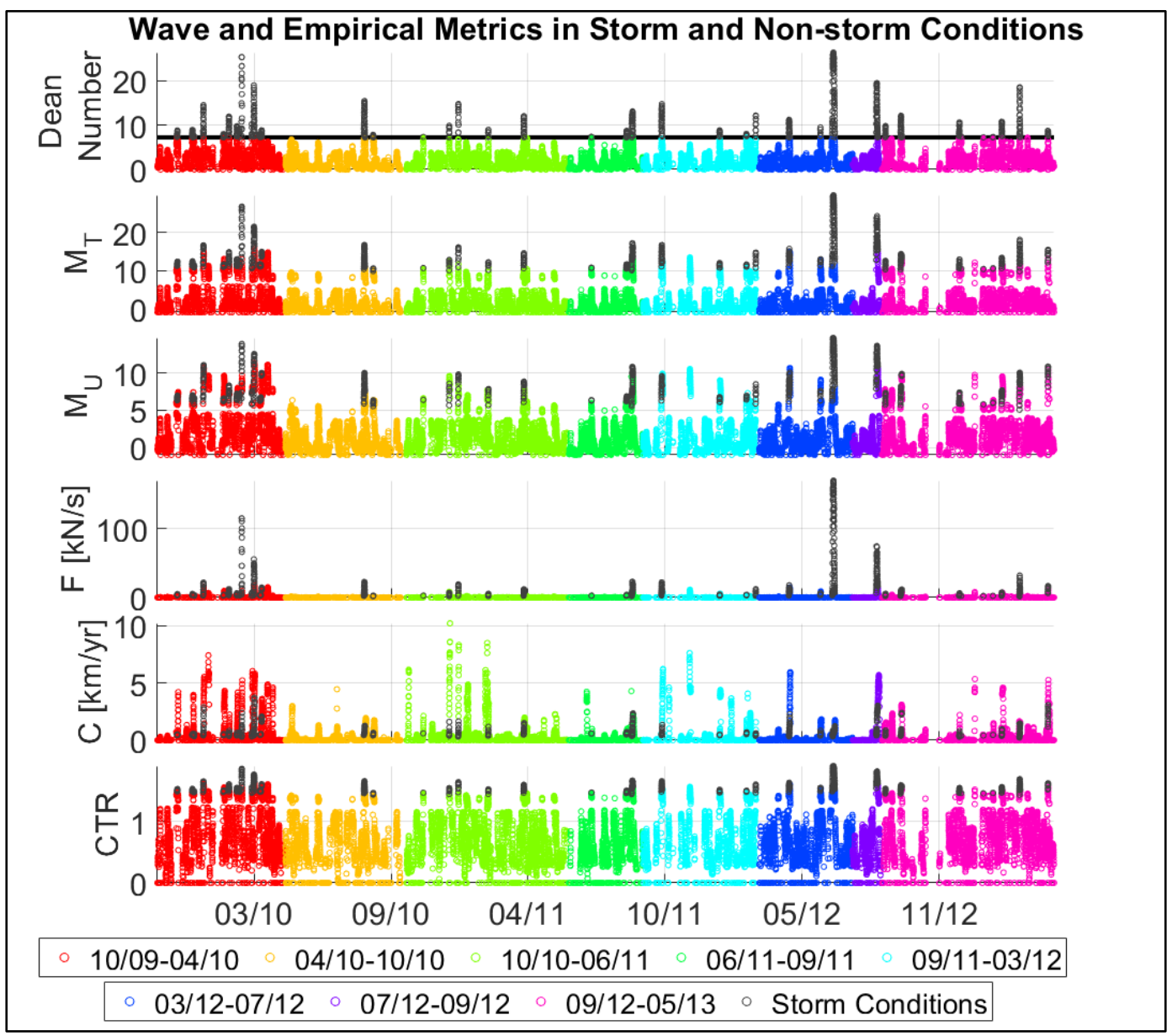


Figure 26. Dean Number, significant wave height, peak period, cosine of wave angle estimate time series between Fort Myers beach surveys transformed from WIS Station 73295 to depth-induced breaking.

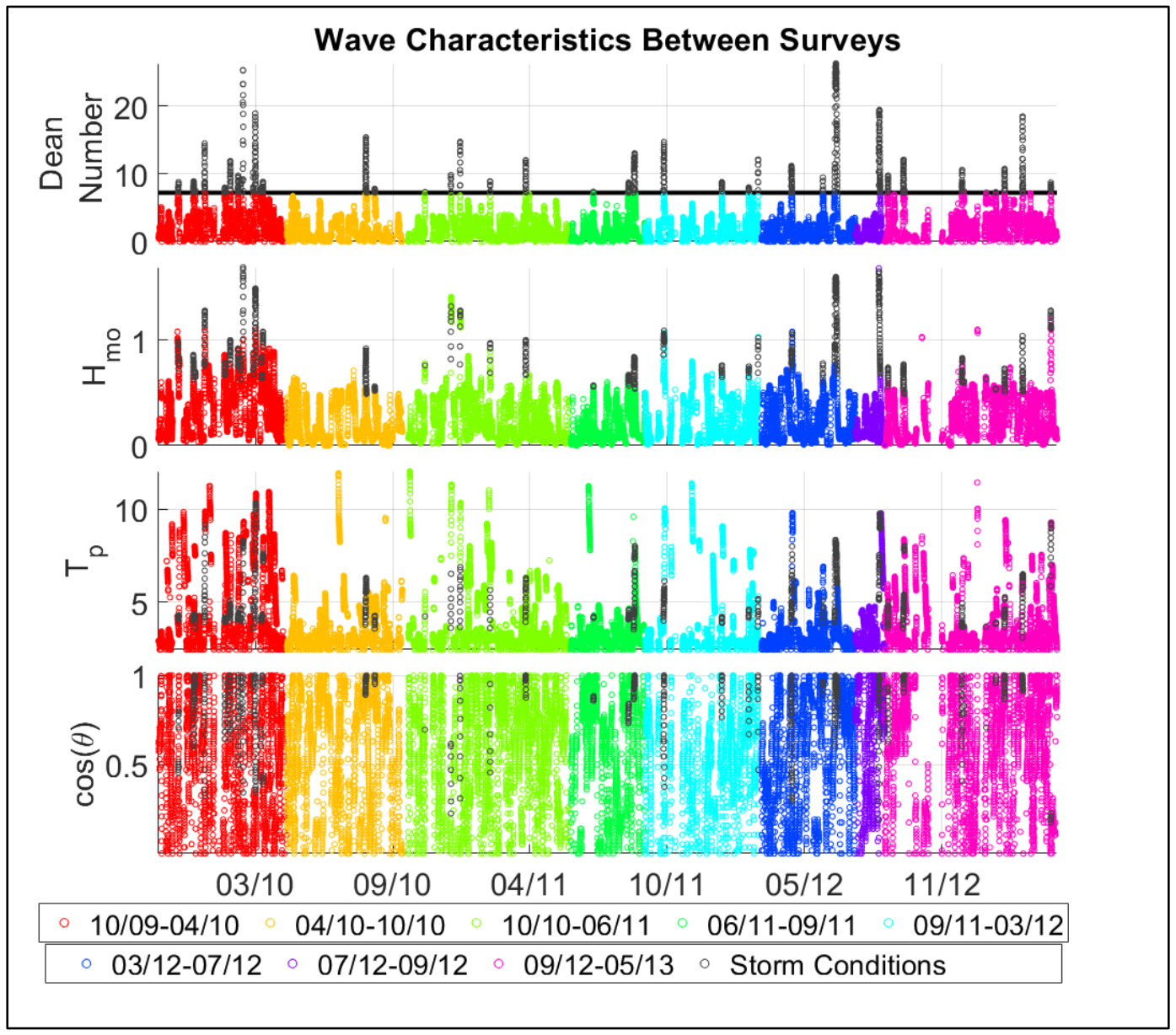

The unanswered question of the relative importance of different waves to nearshore berm morphodynamics is problematic for migration direction predictions. Considering a nearshore berm migration direction prediction over a variety of conditions which include both storm and non-storm waves, the appropriate relative weighting of offshore migration versus onshore migration is not definitive. In this technical report, three storm weighting procedures were investigated: (1) the percentage of the timespan with storm Dean Numbers, (2) the ratio of storm to non-storm Dean Number integrals, and (3) the ratio of storm to non-storm wave energy flux integrals (Table 3 ).

The percentage of the timespan with storm Dean Numbers represents the ratio between the number of hourly Dean Number estimates that are above 7.2 and the number of hourly Dean Number estimates that are below 7.2. The ratio of storm to non-storm Dean Number integrals are 
estimated by summing the product of all of the hourly Dean Numbers during storm conditions and the data time-step and dividing by the sum of the product of the hourly Dean Numbers during non-storm conditions and the data time-step. The ratio of storm to non-storm wave energy flux integrals were estimated by summing the product of all of the hourly wave energy flux estimates during storm conditions and the data time-step, and dividing by the sum of the of the product of the hourly wave energy flux estimates during non-storm conditions and the data time-step. The term integral is used to refer to the result of numeric integration of the hourly data sets for simplicity.

The percentage of times with storm Dean Numbers describe the observed migration directions of the nearshore berm case study poorly. The first timespan had the greatest fraction of storm Dean Numbers but also substantial onshore migration while other timespans have a lesser percentage of storm Dean Numbers and offshore migration. The only periods with net nearshore berm migration offshore had lesser storm Dean Number percentages than two of the timespans with onshore migration. Overall, no single storm Dean Number exceedance percentage limit could separate the timespans with onshore migration from the timespans with offshore migration.

The ratio of storm to non-storm Dean Number integrals is able to describe the observed nearshore berm migration direction. Timespans 6 and 7 were the only time periods with observed net offshore migration as well as the highest storm to non-storm Dean Number integral ratios, the least of which was less than $185 \%$ larger than the largest storm to non-storm ratio corresponding to a period of observed net onshore migration. A storm to non-storm Dean Number sum limit describing nearshore berm migration direction would need to be between 0.331 and 0.604 .

The ratio of storm to non-storm wave energy flux integrals could describe observed migration directions at the case study well. The ratio of the integrals of storm and non-storm wave energy fluxes were more than $500 \%$ larger in periods of net nearshore berm migration offshore. During the timespans in which the nearshore berm migrated onshore storm to nonstorm wave energy flux integral ratios were between 0.47 and 1.35 while during timespans with offshore migration storm to non-storm wave energy flux integral ratios were 7.01 and 14.26 (Table 3). A storm to non-storm wave energy flux integral ratio limit between 1.35 and 7.01 could describe 
the observed net nearshore berm migration directions. While a storm to non-storm Dean Number integral limit does describe nearshore berm migration direction, the storm to non-storm wave energy flux integral ratios were more distinct between offshore and onshore migration.

Table 3. Storm wave statistics between surveys at Fort Myers Beach for wave information transformed from WIS station 73295 to depth-induced breaking.

\begin{tabular}{|c|c|c|c|c|c|}
\hline $\begin{array}{c}\text { Timespan } \\
\text { Number of } \\
\text { Wave Data }\end{array}$ & $\begin{array}{c}\text { Time between } \\
\text { Surveys }\end{array}$ & $\begin{array}{c}\text { The } \\
\text { Percentage of } \\
\text { the Timespan } \\
\text { with Storm } \\
\text { Dean } \\
\text { Numbers }\end{array}$ & $\begin{array}{c}\text { Storm to } \\
\text { Non-Storm } \\
\text { Dean } \\
\text { Number } \\
\text { Integral } \\
\text { Ratios }\end{array}$ & $\begin{array}{c}\text { Storm to } \\
\text { Non-Storm } \\
\text { Wave } \\
\text { Energy Flux } \\
\text { Integral } \\
\text { Ratios }\end{array}$ & $\begin{array}{c}\text { Observed } \\
\text { Nearshore } \\
\text { Berm } \\
\text { Migration } \\
\text { Direction }\end{array}$ \\
\hline $\begin{array}{c}\text { Timespan } \\
\text { Number }\end{array}$ & Timespan & $\%$ Dean $>7.2$ & $\begin{array}{c}\Sigma \text { Dean } \text { storm }:_{\Sigma \text { Deannon-stom }} \\
\Sigma F_{\text {storm } \Delta t:} \text { : }\end{array}$ & $\begin{array}{c}\text { Migration-storm } \Delta t \\
\text { Direction }\end{array}$ \\
\hline 1 & $10 / 09-04 / 10$ & 7.22 & 0.331 & 1.30 & Onshore \\
\hline 2 & $04 / 10-10 / 10$ & 1.59 & 0.113 & 0.96 & Onshore \\
\hline 3 & $10 / 10-06 / 11$ & 1.11 & 0.074 & 0.47 & Onshore \\
\hline 4 & $06 / 11-09 / 11$ & 3.02 & 0.222 & 1.35 & Onshore \\
\hline 5 & $09 / 11-03 / 12$ & 2.75 & 0.183 & 0.57 & Onshore \\
\hline 6 & $03 / 12-07 / 12$ & 5.16 & 0.604 & 14.26 & Offshore \\
\hline 7 & $07 / 12-09 / 12$ & 5.67 & 0.669 & 7.01 & Offshore \\
\hline 8 & $09 / 12-05 / 13$ & 3.34 & 0.163 & 0.73 & Onshore \\
\hline
\end{tabular}

The storm to non-storm wave energy flux integral ratios over all possible combinations of consecutive timespans were considered to further investigate a limiting value which could separate onshore from offshore migration (Table 4). Each combination of consecutive timespans between elevation surveys were investigated to convert the eight observed timespans to 36 net migration observations. The migration direction during 34 of the 36 possible consecutive timespans could be described by a storm to non-storm wave energy flux integral ratio limit of 3.8 (Figure 27). The storm to non-storm wave energy flux integral ratios of the combination of timespans 6, 7, and 8 (March 2012 to May 2013) and timespans 5, 6, 7, and 8 (September 2011 to May 2013) were above 3.8 but described periods of onshore migration. Both timespan combinations that corresponded to net onshore migration with storm to non-storm wave energy flux ratios above 3.8 ended with timespan 8 . 
Waves during timespan 8 were relatively energetic $(\Sigma F$ non-storm $\Delta t=4.83$ $\left.\mathrm{GJm}^{-1}\right)$, could generally be expected to drive onshore transport $\left(\Sigma \mathrm{F}_{\text {storm }} \Delta \mathrm{t}\right.$ : $\Sigma F_{\text {non-storm }} \Delta t=0.73$ ), and impacted a post-storm profile. This may explain part of why periods of time that involved the two largest storms and relatively large $\Sigma F_{\text {storm }} \Delta t: \Sigma F_{\text {non-storm }} \Delta t$ ratios (3.90 and 5.12) ultimately corresponded to net onshore migration. A single storm to non-storm wave energy flux ratio limit does not describe all of the migration directions observed, comparing between multiple surveys but could provide some indication of expected migration directions.

Table 4. Storm wave statistics across consecutive timespans with different migration directions.

\begin{tabular}{|c|c|c|l|}
\hline $\begin{array}{c}\text { Consecutive Date } \\
\text { Range }\end{array}$ & Timespans & $\begin{array}{c}\Sigma F_{\text {storm }} \Delta t: \\
\Sigma F_{\text {non-storm } \Delta t}\end{array}$ & $\begin{array}{l}\text { Migration } \\
\text { Direction }\end{array}$ \\
\hline $09 / 11-07 / 12$ & 5,6 & 6.34 & Offshore \\
\hline $07 / 12-05 / 13$ & 7,8 & 1.82 & Onshore \\
\hline $06 / 11-07 / 12$ & $4,5,6$ & 5.17 & Offshore \\
\hline $03 / 12-05 / 13$ & $6,7,8$ & 5.12 & Onshore \\
\hline $10 / 10-07 / 12$ & $3,4,5,6$ & 3.82 & Offshore \\
\hline $09 / 11-05 / 13$ & $5,6,7,8$ & 3.90 & Onshore \\
\hline $04 / 10-07 / 12$ & $2,3,4,5,6$ & 3.38 & Onshore \\
\hline $06 / 11-05 / 13$ & $4,5,6,7,8$ & 3.59 & Onshore \\
\hline $10 / 09-07 / 12$ & $1,2,3,4,5,6$ & 2.50 & Onshore \\
\hline $04 / 10-09 / 12$ & $2,3,4,5,6,7$ & 3.68 & Onshore \\
\hline $10 / 09-09 / 12$ & $1,2,3,4,5,6,7$ & 2.10 & Onshore \\
\hline $04 / 10-05 / 13$ & $2,3,4,5,6,7,8$ & 2.83 & Onshore \\
\hline
\end{tabular}


Figure 27. Storm wave statistics across all combinations of consecutive timespans and observed migration directions.

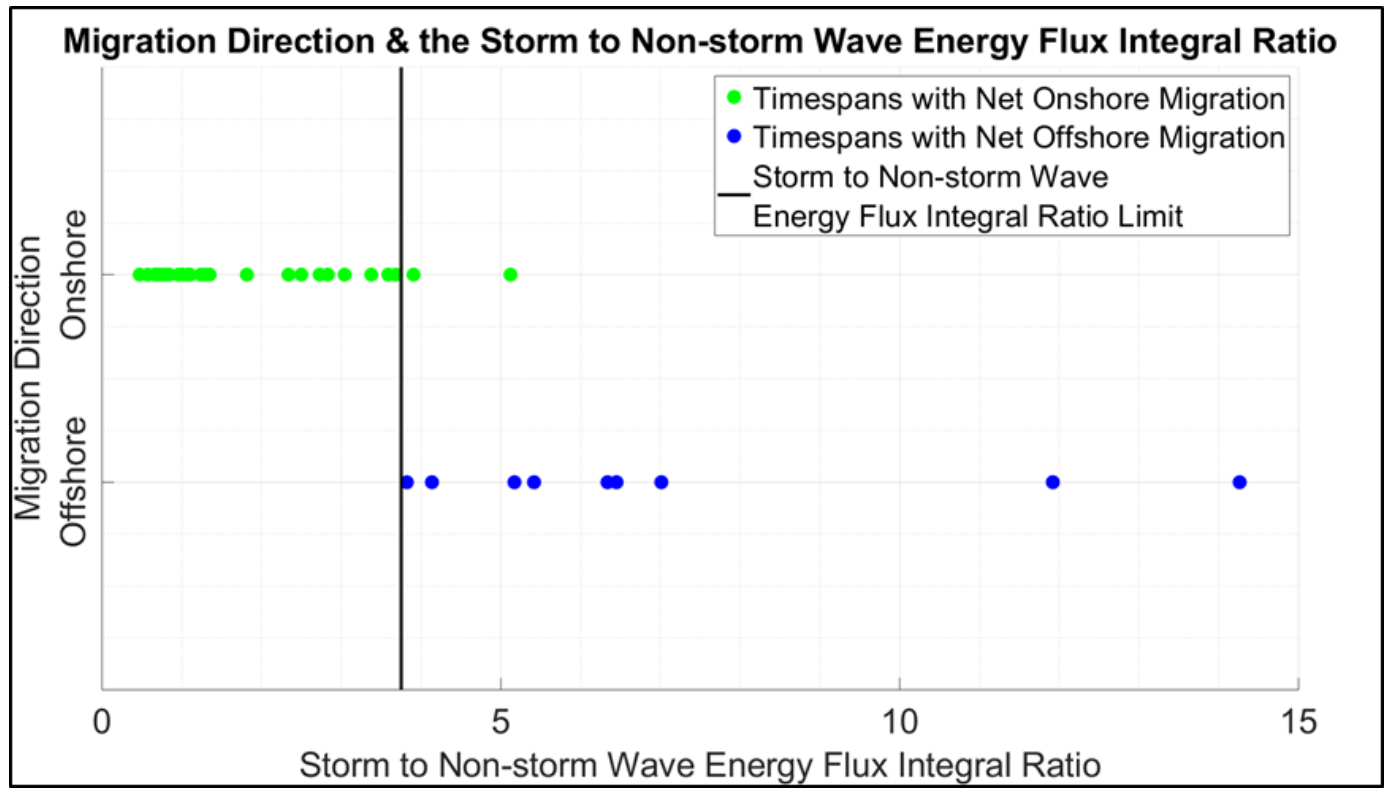

\subsection{Non-storm wave energy flux and nearshore berm morphodynamics}

Correlations between non-storm wave energy flux integrals and gross nearshore berm volume change within the littoral zone could suggest proportionality. Gross volume change can convert bathymetric information into an estimate of net sediment transport. In this context, gross volume change refers to the spatial integral of the absolute value of elevation differences. Gross volume change will always be positive and is not used to describe a transport direction. The term littoral zone refers to points farther offshore than the MLW point on the alongshore averaged profile. Net and foreshore volume changes were also considered, but no potentially useful relationships were discovered. Gross volume change may be modified by adding the net volume change to attempt to correct for sediment transported beyond the boundaries of the domain. Gross littoral zone volume change $\left(\Delta V_{G}\right)$ and corrected gross littoral zone volume change $\left(\Delta V_{G}+|\Delta V|\right)$ were considered.

Gross littoral zone volume change $\left(\Delta V_{G}\right)$ is a representation of net littoral zone sediment transport in all directions and may be calculated from the raster of bathymetry data following Equation 22.

$$
\Delta V_{G}\left(t_{i}\right)=\sum_{j=m l w}^{o f f s h o r e} \sum_{k=1}^{e n d}\left|z\left(x_{j}, y_{k}, t_{i}\right)-z\left(x_{j}, y_{k}, t_{i-1}\right)\right| d y d x
$$


where

$\Delta V_{G}\left(t_{i}\right)=$ gross littoral zone volume change between times $t_{i}$ and $t_{i-1}$ $z\left(x_{j}, y_{k}, t_{i}\right)=$ the elevation raster data at position $x_{j}, y_{k}$, and time $t$

$x_{m l w}=$ the cross-shore position of the point nearest the mean low water datum in the alongshore averaged profile

$x_{\text {offshore }}=$ the offshore limit for data consideration

$y_{1}, y_{\text {end }}=$ alongshore boundaries of elevation data

$d x=$ elevation raster cross-shore grid spacing

$d y=$ elevation raster alongshore grid spacing.

Gross littoral zone volume change corresponds to the sum of the sediment transport into or out of the domain and twice the transport within the considered domain. The different weighting of transport within the domain and transport outside of the domain may be addressed to some degree by adding the net littoral zone volume change. Corrected gross littoral zone volume change is calculated as the sum of gross littoral zone volume change $\left(\Delta V_{G}\right)$ and the magnitude of net littoral zone volume change $(|\Delta V|)$. Net littoral zone volume change may be calculated as the integral of the elevation differences between subsequent elevation rasters (Equation 23).

$$
\Delta V\left(t_{i}\right)=\sum_{j=m l w}^{o f f s h o r e} \sum_{k=1}^{e n d}\left(z\left(x_{j}, y_{k}, t_{i}\right)-z\left(x_{j}, y_{k}, t_{i-1}\right)\right) d y d x
$$

where

$$
\Delta V\left(t_{i}\right)=\text { net littoral zone volume change between times } t_{i} \text { and } t_{i-1 .}
$$

The corrected gross littoral zone volume change is a representation of the net sediment transport in all directions. Gross and corrected gross littoral zone volume changes were calculated for each timespan with onshore migration and compared with non-storm wave energy flux integrals (Table 5). 
Table 5. Non-storm wave energy flux integral and gross littoral zone volume change.

\begin{tabular}{|c|c|c|c|c|}
\hline $\begin{array}{c}\text { Timespan Number } \\
\text { of Wave Data }\end{array}$ & $\begin{array}{l}\text { Time between } \\
\text { Surveys with } \\
\text { Onshore Migration }\end{array}$ & $\begin{array}{l}\text { Non-Storm Wave } \\
\text { Energy Flux Integral }\end{array}$ & $\begin{array}{l}\text { Gross Littoral Zone } \\
\text { Volume Change }\end{array}$ & $\begin{array}{l}\text { Corrected Gross } \\
\text { Littoral Zone Volume } \\
\text { Change }\end{array}$ \\
\hline Timespan Number & Timespan & $\begin{array}{c}\Sigma F_{\text {non-storm }} \Delta t \\
{\left[G J m^{-1}\right]}\end{array}$ & $\Delta V_{G}\left[\mathrm{~m}^{3}\right]$ & $\Delta V_{G}+|\Delta V|\left[\mathrm{m}^{3}\right]$ \\
\hline 1 & $10 / 09-04 / 10$ & 7.94 & 92,500 & 104,000 \\
\hline 2 & $04 / 10-10 / 10$ & 1.69 & 40,000 & 43,700 \\
\hline 3 & 10/10-06/11 & 2.64 & 55,200 & 55,400 \\
\hline 4 & $06 / 11-09 / 11$ & 1.53 & 31,000 & 34,900 \\
\hline 5 & 09/11-03/12 & 2.90 & 48,200 & 51,300 \\
\hline 8 & $09 / 12-05 / 13$ & 4.83 & 62,000 & 75,300 \\
\hline
\end{tabular}

During periods of onshore migration, the $R^{2}$ value of the correlation between gross littoral zone volume change and the non-storm wave energy flux integral was above 0.94 with a $p$ value of 0.00113 (Figure 28). The $R^{2}$ value of the correlation between corrected gross littoral zone volume change and the non-storm wave energy flux integral was above 0.98 with a $p$ value of 0.000131 (Figure 28). The greater $R^{2}$ and lower $p$ value of the corrected gross littoral zone volume change could support the validity of the correction applied for gross volume change. A major flaw with any correlations using only a dataset collected for a single nearshore berm without exceptionally temporally dense sampling will be the lack of data.

The impact of the limited number of data points on the significance of the correlations computed may be addressed in some capacity with $p$ values. Lower $p$ values can indicate more significance and $p$ values below 0.05 , 0.01 , and 0.001 have been described as statistically significant. The high $R^{2}$ and low $p$ value of the relationship between the non-storm wave energy flux integral and both corrected and uncorrected gross littoral zone volume change could indicate a robust relationship between wave energy flux and the net quantity of sediment transported at the Fort Myers Beach nearshore berm. The $R^{2}$ of 0.981 and $p$ value of 0.000131 for the linear relationship between the non-storm wave energy flux integral and an approximation for net littoral zone sediment transport indicates that nonstorm wave energy flux may be an important metric for predictions involving the quantity of sediment transported in similar conditions. 
Figure 28. The relationship between gross or corrected gross littoral zone volume changes and non-storm wave energy flux integrals.

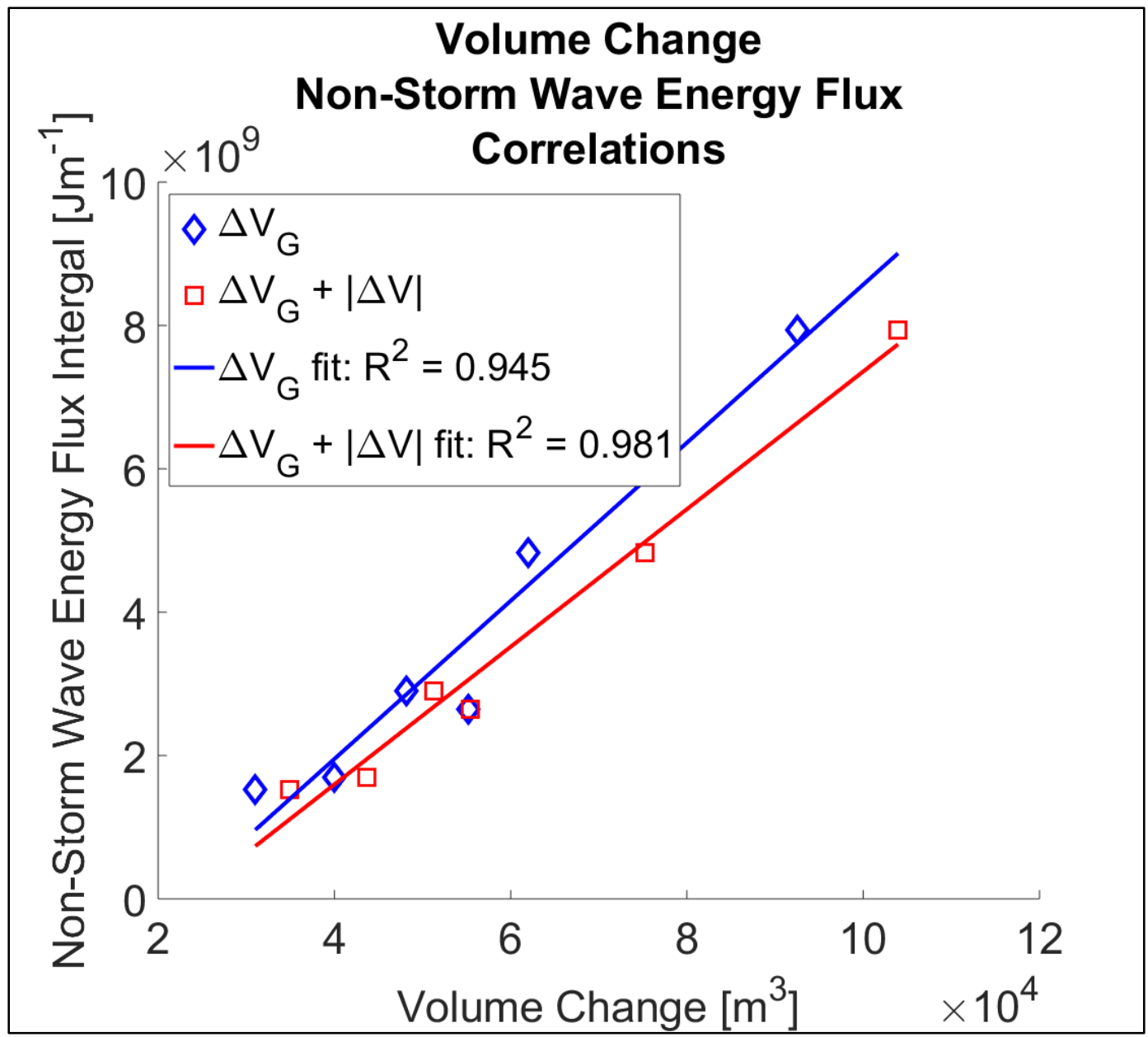

Several traits of the relationships between volume changes and non-storm wave energy flux integrals are supported by physical intuition. The relative magnitude of the wave energy flux axis intercept and the positive slope support the physical intuition that particularly low energy waves transport negligible volumes of sediment and particularly energetic waves transport substantial volumes of sediment. The small magnitude of the wave energy flux axis intercept relative to the mean wave energy flux limits the extent of the troublesome case of particularly small wave energy flux integrals corresponding to negative volume changes. All gross littoral zone volume changes yielded generally physically reasonable relationships with nonstorm wave energy flux integrals.

Several factors could have artificially inflated correlation scores with volume change. Nearshore berm shape impact and seasonal variations that are not described by wave energy flux may have contributed to 
erroneously high correlations between gross littoral zone volume changes and non-storm wave energy flux integrals. Morphologic change at nearshore berms is often greatest following construction (Bryant and McFall 2016), which also happens to have been the timespan with the largest non-storm wave energy flux integral at the Fort Myers Beach nearshore berm. The decrease in nearshore berm morphologic change which has been observed to follow some period immediately after construction could be related to the shape of the nearshore berm, particularly the slope of the offshore edge. Nearshore berms with steeper offshore slopes could be expected to transport more sediment corresponding with more extreme system perturbations and narrower dissipation windows. The two timespans in which the estimates of transported sediment volumes are highest were also following the steepest measured offshore slopes. The large volume of transported sediment estimated for timespan 8 could be related to the shape and steep offshore slope of the post-storm survey in September 2012 (timespan 7). The impact of elevation profile similarities at the ends of timespans 1 and 8 on processes not related to wave energy flux may have contributed to an erroneously high $\mathrm{R}^{2}$ statistic.

Seasonal variability may have also inflated the correlation between the estimates for total sediment transported and the non-storm wave energy flux integral. Excluding timespans 6 and 7, the three timespans with the largest transported sediment volume estimates were predominately fall and winter months. The two timespans other than timespans 6 and 7 with the smallest estimates of transported sediment volumes contained predominantly spring and summer months. The impacts of the nearshore berm shape and the seasonal variability which is not related to wave energy flux are not considered thoroughly. No data indicates nearshore berm shape or non-wave energy flux related seasonal variations influenced transported sediment volumes in the littoral zone around the nearshore berm at Fort Myers Beach, but the lack of additional data to compare against means that they could have inflated the correlations which are presented in this technical report.

The relevance of the correction applied to gross volume changes may be addressed with the correlations and $p$ values of relationships between the non-storm wave energy flux integral and gross littoral zone volume change with and without the correction (Table 5, Figure 28). Correlations between the available data indicate that wave energy flux is more directly 
proportional to the sum of gross volume change and the magnitude of net volume change than gross volume change, and $p$ values were an order of magnitude lower, so the correction is suggested to be reasonable. Correlations determined with the available data suggest that in this case wave energy flux is most directly proportional to the net volume of sediment transported in the littoral zone.

Bathymetry data of the nearshore berm at Fort Myers Beach appear to indicate that in this scenario the net volume of transported sediment was proportional to the time-integral of non-storm wave energy flux. A linear relationship connects the time-integral of non-storm wave energy flux and an approximation for the net volume of sediment transported in the littoral zone. During timespans containing large storm events in which the time-integral of storm wave energy flux was substantially larger than nonstorm wave energy flux, the nearshore berm appeared to move offshore and steepen. During timespans with energetic non-storm conditions, in which the time-integral of storm wave energy flux was a similar magnitude to the time-integral of non-storm wave energy flux, the nearshore berm appeared to migrate onshore and flattened faster than in times with low energy non-storm conditions. The relationship between net volumes of transported sediment may be proportional to non-storm wave energy flux. The combination of the nearshore berm survey data and WIS hindcast wave data indicate that the ratio of storm to non-storm wave energy flux integrals may describe nearshore berm migration direction well and that non-storm wave energy flux integrals may describe the volume of sediment transported during a period of onshore migration. 


\section{Discussion}

This technical report addresses procedures for selecting characteristic wave conditions for scoping level predictions of nearshore berm morphodynamic time scales. The most relevant questions that could not be answered were related to the ability of various wave or empirical metrics to describe nearshore berm morphodynamics and the relative importance of ongoing processes and peak extreme events. Relevant predictive metrics and timescales were investigated with the elevation data of the 2009 nearshore berm placement off of Fort Myers Beach. Analysis of bathymetry data and WIS hindcast data may suggest that relatively frequent events with return intervals below 1 year drove nearshore berm morphologic change, apparent migration direction was described well by a storm to non-storm wave energy flux integral ratio limit of 3.82 , and a representation of the net quantity of transported sediment may be proportional to the non-storm wave energy flux during periods of net onshore migration.

\subsection{Relevant timescales for nearshore berm evolution}

The timespans at which nearshore berms evolve and the recurrence interval of the events which drive nearshore berm morphodynamics are not particularly well understood. The appropriate wave averaging procedure for scoping level predictions of nearshore berm morphodynamics depends on the return intervals of events which are important. If nearshore berm morphodynamics are driven by events which commonly occur, then a wave averaging procedure which captures the average conditions over a given timespan (Chapter 2.2) will be most applicable. If nearshore berm morphodynamics are driven by infrequent extreme events, then an averaging procedure that captures the peak event or events in a given timespan (Chapter 2.3) will be most appropriate.

Observed morphologic changes indicate that the nearshore berm at Fort Myers beach may have evolved predominantly as the result of events with frequencies less than 1 year. Although extreme events (Hurricane Isaac, and Tropical Storm Debby) occurred during the study duration, overall, the nearshore berm migrated onshore. The nearshore berm appears to have migrated onshore during common conditions and offshore during storm conditions. Offshore migrations were short lived, and the recovery period following the second storm appears to have moved the second largest 
quantity of sediment onshore. The relative importance of storm events on nearshore berm morphodynamics is expected to vary between sites. Analysis in this report was limited to the measurements from the nearshore berm at Fort Myers Beach but may suggest that averaging procedures that capture typical mean conditions are most applicable to describe nearshore berm morphodynamics, which should be analyzed in future studies.

\subsection{Relevant metrics for nearshore berm cross-shore migration direction}

Scoping level tools are likely to be applicable to cross-shore migration direction predictions. A previous study of sandbars near Duck, NC, by Larson and Kraus (1992) indicated that a Dean Number limit of 7.2 could separate conditions in which sandbars migrated onshore (<7.2) from conditions in which sandbars migrated offshore (>7.2). Following the observations of sandbars and nearshore berms moving offshore during storms and onshore during non-storm conditions, the Dean Number limit of 7.2 could be applied to distinguish storm and non-storm conditions for nearshore berm analysis.

Wave energy flux peaks were found to correspond most directly with Dean Numbers above 7.2 in the linear transformation of WIS hindcast data to the nearshore berm at Fort Myers Beach. The ratio of wave energy flux integrals between storm and non-storm conditions was found to distinguish periods of net onshore migration from periods of net offshore migration for the nearshore berm at Fort Myers Beach. For the six timespans over which net onshore migration was observed, the ratios of the wave energy flux integral over the storm conditions to the wave energy flux integral over the nonstorm conditions were between 0.47 and 1.35. For the two timespans in which net offshore migration was observed, the ratios of the wave energy flux integral over the same conditions were 7.01 and 14.26. Morphology data of the nearshore berm at Fort Myers Beach suggest that an indicator of net nearshore berm migration onshore could be a storm to non-storm wave energy flux integral ratio less than 3.8, defining storm conditions with a Dean Number limit of 7.2. While a simple Dean Number limit does not necessarily provide an indicator for migration direction over a variety of conditions, a storm to non-storm wave energy flux integral ratio limit could predict migration direction over timespans of varied conditions. 


\subsection{Relevant metrics for nearshore berm morphodynamics}

The quantity of sediment transported is an important element of nearshore berm morphodynamics and would be a particularly helpful estimate for a scoping level tool to provide. Approximations for net transported sediment volume may be inferred from elevation differences between consecutive surveys. The sum of gross volume change and the magnitude of net volume change should approximate twice the net volume of transported sediment and is referred to as the corrected gross volume change. For timespans in which onshore migration was observed, the time-integral of non-storm wave energy flux was found to be proportional to gross volume change within the littoral zone with an $R^{2}$ value of 0.945 and $p$ value of 0.00113 and to corrected gross littoral zone volume change with an $\mathrm{R}^{2}$ value of 0.981 with a $p$ value of 0.000131. Data from the nearshore berm at Fort Myers Beach indicate that the time-integral of wave energy flux may be important to the quantity of sediment transported at nearshore berms, and in this case may even be proportional. 


\section{Conclusions}

Nearshore berms can provide an option to beneficially use dredged sediment, keep sediment in the littoral system, possibly alter erosive hydrodynamic conditions, and add material to the existing beach profile in solutions consistent with the principles of RSM and Engineering With Nature. Key research questions on nearshore berms relate to the stakeholder and regulatory agency interest in the extent and timescale of nearshore berm migration and diffusion and the impact of nearshore berms on local shorelines. Previous research, guidance, and tools have addressed estimates of nearshore berm morphodynamics including but not limited to nearshore berm stability and migration direction. Scoping level tools may be able to provide more detailed estimates of nearshore berm morphodynamics, while maintaining reasonable computational, expertise, labor, and site information requirements. Scoping level estimates of nearshore berm morphodynamics are expected to benefit from predictions of representative wave climate conditions over durations similar to nearshore berm lifespans.

Characteristic wave climate information over a given timespan may be selected to match the mean or peak conditions over the duration of interest. The procedure presented to determine representative mean conditions selects the timespan of equal duration to the predication with mean conditions most similar to the mean of the distribution of averages (Section 2.2). The procedure presented to determine representative peak conditions selects the quarter year with an average which best matches the appropriate return interval (Section 2.3). The relevance of both representative condition determination procedures depends on the relevance of the wave characteristics being matched.

The relevance of a variety of combinations of wave climate characteristics was addressed through the comparison of several wave and empirical nearshore berm metrics with morphology observations at the 2009 nearshore berm placement at Fort Myers Beach. Estimates of significant wave height, peak period, mean wave direction, sediment mobility index, Dean Number, wave energy flux, the Douglass (1995) empirical migration coefficient, and the Hwung (2010) cumulative transport rate were compared with a wide variety of estimates for nearshore berm morphodynamic traits including nearshore berm height, migration direction, migration rate, and volume with generally poor correlations. 
Two relationships connecting wave metrics to nearshore berm morphologic change were developed.

A relationship involving both Dean Number and wave energy flux described the nearshore berm migration directions at Fort Myers Beach with some success. Times in which the Larson and Kraus (1992) Dean Number limit indicates offshore migration (Dean Number > 7.2) were defined as storms, following the expectation of nearshore berms to migrate offshore during storm conditions and onshore during non-storm conditions. The ratios between the time integrals of storm and non-storm wave energy fluxes were able to describe $91 \%$ of the observed migration directions at Fort Myers Beach. A storm to non-storm wave energy flux integral ratio limit of 3.8 could provide some basic prediction of migration direction for the specific conditions observed.

The time integral of wave energy flux during non-storm conditions was found to correlate with several variants of the gross volume change. Gross volume change was defined as the spatial integral of the absolute value of elevation change. Net volume change was defined as the spatial integral of elevation change and was applied as a correction to gross volume changes. All correlations were determined specifically with the elevation changes farther offshore than the mean low water line. The time-integral of nonstorm wave energy flux during timespans with onshore migration was proportional to gross littoral zone volume change with an $R^{2}$ value above 0.94 and corrected gross littoral zone volume change with an $R^{2}$ value above 0.98. Corrected gross volume change theoretically represents net sediment transport. Wave energy flux during timespans with Dean Numbers less than 7.2 may be an important metric to investigate nearshore berms in similar conditions.

Elevation data collected at the 2009 nearshore berm placement at Fort Meyers Beach may indicate that the storm to non-storm wave energy flux integral ratio and also possibly the non-storm wave energy flux integral are important metrics of representative wave climates, where storm conditions are separated from non-storm conditions by a Dean Number of 7.2. The storm to non-storm wave energy flux integral ratio may be important for migration direction predictions and the non-storm wave energy flux integral may be important to net sediment transport volume estimates. The data presented in this technical report were limited to 10 surveys, which corresponds to eight timespans of post-construction 
morphologic change. Considering only eight times at one nearshore berm limits the generality of conclusions to other berms and a wider range of conditions, but this report does detail a viable method of analysis for other nearshore berms as data sets become available. The analysis conducted in this technical report is intended to contribute additional information towards nearshore berm morphodynamic estimation capabilities. More research is required to provide answers to the fundamental research questions about nearshore berms of where and how fast sediment placed in the nearshore will be transported and how the shoreline will respond to the placed sediment. Further research is recommended using field studies, physical models, and numerical models to address these key questions. 


\section{References}

Ahrens, J. P., and E. B. Hands. 1998. "Velocity Parameters for Predicting Cross-Shore Sediment Migration.” Journal of Waterway, Port, Coastal, and Ocean Engineering 124(1): 16-20.

Andrassy, C. J. 1991. "Monitoring of a Nearshore Disposal Mound at Silver Strand State Park. Proceedings, Coastal Sediments '91, American Society of Civil Engineers, 1970-1984.

Arnold, D. E., B. C. McFall, K. E. Brutsché, E. C. Maloney, and D. F. Bucaro. 2018. Nearshore Placement Techniques in Southern Lake Michigan. ERDC/CHL TR18-3. Vicksburg, MS: US Army Engineer Research and Development Center.

Bailard, J. A., and D. L. Inman. 1981. “An Energetics Bedload Model for a Plane Sloping Beach: Local Transport.” Journal of Geophysical Research: Oceans $86\left(\mathrm{C}_{3}\right)$ : 2035-2043.

Balsillie, J. H., and R. R. Clark. 1992. The Gulf Coast of Florida: Overview of Physiography, Geology, and Historical Shoreline Change. Florida Department of Natural Resources, Division of Beaches and Shores.

Barnard, P. L., L. H. Erikson, J. E. Hansen, and E. Elias. 2009. The Performance of Nearshore Dredge Disposal at Ocean Beach, San Francisco, California, 20052007. US Geological Survey Open-File Report 2008-13. http://pubs.usgs.gov/of/2008/1347/

Bascom, W. N. 1953. "Characteristics of Natural Beaches." Coastal Engineering Proceedings 1(4): 10.

Birchler, J. J., H. F. Stockdon, K. S. Doran, and D. M. Thompson. 2014. National Assessment of Hurricane-Induced Coastal Erosion Hazards: Northeast Atlantic Coast. No. 2014-1243. US Geological Survey.

Bodge, K. R. 1994. "Performance of Nearshore Berm Disposal at Port Canaveral, Florida. Dredging'94, 1182-1191. ASCE.

Brutsché, K. E. 2011. First Year Sedimentological Characteristics and Morphological Evolution of an Artificial Berm at Fort Myers Beach, Florida. Master of Science thesis. University of South Florida.

Brutsché, K. E. 2014. Evolution and Equilibration of Artificial Morphologic Perturbations in the Form of Nearshore Berm Nourishments along the Florida Gulf Coast. PhD dissertation. University of South Florida.

Brutsché, K. E., P. Wang, T. M. Beck, J. D. Rosati, and K. R. Legault. 2014. "Morphological Evolution of a Submerged Artificial Nearshore Berm along a Low-Wave Microtidal Coast, Fort Myers Beach, West-Central Florida, USA." Coastal Engineering 91: 29-44.

Brutsché, K. E., B. C. McFall, H. Li, J. E. McNinch, J. D. Ousley, J. A. Engle, and C. K. Maglio. 2017. "Strategic Nearshore Placement of Dredged Sediment at Vilano Beach, Florida." Shore and Beach 85(3): 77-84. 
Bryant, D. B., and B. C. McFall. 2016. "Transport of Nearshore Dredge Material Berms." Proceedings, CoastLab 2016, Ottawa, Canada, 1O-13 May 2016.

Burke, C. E., and M. C. Allison. 1992. Length and End Slope Considerations, Interim Design Guidance Update for Nearshore Berm Construction. Technical Note DRP-5-06. Vicksburg, MS: US Army Engineer Waterways Experiment Station.

Cheng, J., P. Wang, and E. R. Smith. 2015. "Hydrodynamic Conditions Associated with an Onshore Migrating and Stable Sandbar.” Journal of Coastal Research 32(1): 153163 .

Dalrymple, R. A. 1992. "Prediction of Storm/Normal Beach Profiles." Journal of Waterway, Port, Coastal, and Ocean Engineering 118(2): 193-200.

Dean, R. G., and R. A. Dalrymple. 1984. Water Wave Mechanics for Engineers and Scientists. Advanced Series on Ocean Engineering. Vol. 2. Singapore: World Scientific Publishing Company.

Dean, R. G., R. A. Dalrymple. 2002. Coastal Processes with Engineering Applications. United Kingdom: Cambridge.

Demirbilek, Z., L. Lin, J. Smith, E. Hayter, E. Smith, J. Z. Gailani, G. J. Norwood, and D. R. Michalsen. 2010. Waves, Hydrodynamics and Sediment Transport Modeling at Grays Harbor, WA. ERDC/CHL-TR-10-13. Vicksburg, MS: US Army Engineer Research and Development Center.

Douglass, S. L. 1995. "Estimating Landward Migration of Nearshore Constructed Sand Mounds." J. Waterw. Port Coast. Ocean Eng. 121(5): 247-250.

Douglass, S. L. 1997. "Nearshore Placement of Sand." Coastal Engineering 1996, 37083721.

Gunyakti, A. 1987. "Beach Preservation by Means of Offshore Submerged Mound of Dredged Materials.” Coastal Zone '87, 2461-2471. ASCE.

Hallermeier, R. J. 1978. "Uses for a Calculated Limit Depth to Beach Erosion.” Proceedings, Coastal Engineering 1978: 1493-1512.

Hallermeier, R. J. 1981. "A Profile Zonation for Seasonal Sand Beaches from Wave Climate.” Coastal Eng. 4: 253-277.

Hands, E. B., and M. C. Allison. 1991. "Mound Migration in Deeper Water and Methods of Categorizing Active and Stable Depths." Proceedings of Coastal Sediments '91, American Society of Civil Engineers, 1985-1999.

Hands, E. B., and S. R. DeLoach. 1984. "An Offshore Mound Constructed of Dredged Material. Dredging and Dredged Material Disposal." Proceedings of the Conference Dredging '84, American Society of Civil Engineers, NY, 1030-1039.

Hwung, H., Z. Huang, and K. Hwang. 2010. "An Experimental Study of the Cross-Shore Evolution of Artificial Submerged Sand Bars." Coastal Eng. 52(4): 261-285.

Johnson, C. R. 2005. Migration of Dredged Material Mounds: Prediction Based on Field Measurements of Waves, Currents, and Suspended Sediments, Brunswick, Georgia. MS thesis. School of Civil and Environmental Engineering, Georgia Institute of Technology, Atlanta, Georgia. 
Larson, M., N. C. Kraus. 1992. Analysis of Cross-Shore Movement of Natural Longshore Bars and Material Placed to Create Longshore Bars. Technical Report DRP-925. Vicksburg, MS: US Army Engineer Waterways Experiment Station.

McFall, B. C., K. E. Brutsché, J. D. Ousley, C. K. Maglio, and J. A. Engle. 2017. "Innovative Nearshore Berm Placement Techniques at Vilano Beach, FL and Application of the Sediment Mobility Tool." World of Dredging 51(1/2): 34-35.

McFall, B. C., S. J. Smith, C. E. Pollock, J. Rosati, III, and K. E. Brutsché. 2016. Evaluating Sediment Mobility for Siting Nearshore Berms. ERDC/CHL CHETNIV-108. Vicksburg, MS: US Army Engineer Research and Development Center.

McLellan, T. 1990. Engineering Design Considerations for Nearshore Berms. Technical Note DRP-5-01. Vicksburg, MS: US Army Engineer Waterways Experiment Station.

McLellan, T. N., N. C. Kraus, and C. E. Burke. 1990. Interim Design Guidance for Nearshore Berm Construction. Technical Note DRP-5-02. Vicksburg, MS: US Army Engineer Waterways Experiment Station.

Mesa, C. 1996. "Nearshore Berm Performance at Newport Beach, California, USA." Proceedings of Coastal Engineering 1996, American Society of Civil Engineers.

Myrhaug, D. 1989. “A Rational Approach to Wave Friction Coefficients for Rough, Smooth, and Transitional Turbulent Flow." Coastal Engineering 13(1): 11-21.

Nielsen, P. 1992. "Coastal Bottom Boundary Layers and Sediment Transport." Advanced Series on Ocean Engineering, Vol. 4. Singapore: World Scientific Publishing Company.

Otay, E. N. Long-Term Evolution of Nearshore Disposal Berms. PhD dissertation. Coastal and Oceanographic Engineering Department, University of Florida, Gainesville, FL.

Poff, M. T., and M. F. Stephen. 1998. "Southwest Florida Regional Sediment Budget." In Proceedings, National Conference on Beach Preservation Technology, St. Petersburg, Florida.

Pollock, C. B., and M. C. Allison. 1993. Berm Crest Width Considerations, Interim Design Guidance Update for Nearshore Berm Construction. Technical Note DRP-5-08. Vicksburg, MS: US Army Engineer Waterways Experiment Station.

Russell, P. E. 1993. "Mechanisms for Beach Erosion during Storms." Continental Shelf Research 13(11): 1243-1265.

Salinger, M. J., C. J. Stigter, and H. P. Das. 2000. "Agrometeorological Adaptation Strategies to Increasing Climate Variability and Climate Change.” Agricultural and Forest Meteorology 103(1-2): 167-184.

Shepard, D. 1968. "A Two-Dimensional Interpolation Function for Irregularly-Spaced Data." Proceedings of the 1968 23rd ACM National Conference, 517-524. ACM.

Smith, E. R., R. Permenter, M. C. Mohr, and S. A. Chader. 2015. Modeling of NearshorePlaced Dredged Material. ERDC/CHL-TR-15-9. Vicksburg, MS: US Army Engineer Research and Development Center. 
Smith, E. R., F. D'Alessandro, G. R. Tomasicchio, and J. Z. Gailani. 2017a. "Nearshore Placement of a Sand Dredged Mound." Coastal Engineering 126: 1-10.

Smith, E. R., M. C. Mohr, and S. A. Chader. 2017b. "Laboratory Experiments on Beach Change Due to Nearshore Mound Placement." Coastal Engineering 121: 119-128.

Soulsby, R. L. 1997. Dynamics of Marine Sands. London, England: Thomas Telford Publications.

Soulsby, R. L., and R. J. Whitehouse. 1997. "Threshold of Sediment Motion in Coastal Environments." Proceedings of Pacific Coasts and Ports '97 Conference (1):149154. Christchurch: University of Canterbury, New Zealand.

Stockdon, H. F., K. S. Doran, K. L. Sopkin, D. M. Thompson, and N. G. Plant. 2013. National Assessment of Hurricane-Induced Coastal Erosion Hazards: MidAtlantic Coast.

Styles, R., M. E. Brown, K. E. Brutsché, H. Li, T. M. Beck, and A. Sánchez. 2018. LongTerm Morphology Modeling for Barrier Island Tidal Inlets. ERDC/CHL TR-1812. Vicksburg, MS: US Army Engineer Research and Development Center, Coastal and Hydraulics Laboratory.

USACE (US Army Corps of Engineers). 1969. Beach Erosion Control Study on Lee County, Florida. Jacksonville, FL: USACE, Jacksonville District.

USACE. 2001. Lee County, Florida Shore Protection Project (Gasparilla and Estero Islands) General Reevaluation Report with Final Environmental Statement. Jacksonville, FL: USACE, Jacksonville District.

Vera-Cruz, D. 1972. "Artificial Nourishment of Copacabana Beach." Proc. 13th Intl. Conf. Coastal Eng., 1451-1463. Vancouver: ASCE.

Wang, P., K. E. Brutsché, J. W. Lagrone, T. M. Beck, J. D. Rosati, and L. S. Lillycrop. 2013. Performance Monitoring Of a Nearshore Berm at Fort Myers Beach, Florida: Final Report. ERDC/CHL TR-13-11. Vicksburg, MS: US Army Engineer Research and Development Center.

Walton, Todd L. 1973. Littoral Drift Computations along the Coast of Florida by Means of Ship Wave Observations. Coastal and Oceanographic Engineering Laboratory, University of Florida.

Zwamborn, J. A., G. A. Fromme, and J. B. Fitzpatrick. 1970. "Underwater Mound for the Protection of Durban's Beaches.” Proc. 12th Int. Conf. Coastal Eng., 975-994.

ASCE. 


\section{Unit Conversion Factors}

\begin{tabular}{|l|c|l|}
\hline Multiply & \multicolumn{1}{l|l|}{ By } & To Obtain \\
\hline cubic yards & 0.7645549 & cubic meters \\
\hline degrees (angle) & 0.01745329 & radians \\
\hline feet & 0.3048 & meters \\
\hline foot-pounds force & 1.355818 & joules \\
\hline horsepower (550 foot-pounds force per second) & 745.6999 & watts \\
\hline inches & 0.0254 & meters \\
\hline miles (nautical) & 1,852 & meters \\
\hline miles (US statute) & $1,609.347$ & meters \\
\hline miles per hour & 0.44704 & meters per second \\
\hline ounces (mass) & 0.02834952 & kilograms \\
\hline pounds (force) & 4.448222 & newtons \\
\hline quarts (US liquid) & $9.463529 \mathrm{E}-04$ & cubic meters \\
\hline tons (force) & $8,896.443$ & newtons \\
\hline yards & 0.9144 & meters \\
\hline
\end{tabular}




\section{Acronyms and Abbreviations}

$\begin{array}{ll}\text { FRF } & \text { Field Research Facility } \\ \text { MATLAB } & \text { Matrix Laboratory } \\ \text { MHW } & \text { mean high water } \\ \text { MLW } & \text { mean low water } \\ \text { MSL } & \text { mean sea level } \\ \text { NAVD88 } & \text { North American Vertical Datum of 1988 } \\ \text { NOAA } & \text { National Oceanic and Atmospheric Administration } \\ \text { PDE } & \text { partial differential equation } \\ \text { RSM } & \text { Regional Sediment Management } \\ \text { RTK GPS } & \text { Real Time Kinematic Global Positioning System } \\ \text { SMS } & \text { Surface Modeling System } \\ \text { SMT } & \text { Sediment Mobility Tool } \\ \text { USACE } & \text { United States Army Corps of Engineers } \\ \text { USF-CRL } & \text { University of South Florida Coastal Research Lab } \\ \text { WIS } & \text { Wave Information Services } \\ \text { N } & \end{array}$




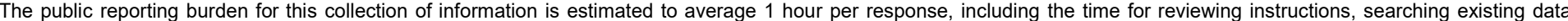

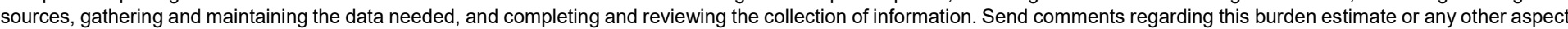

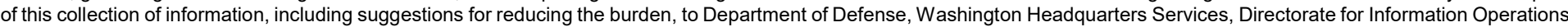

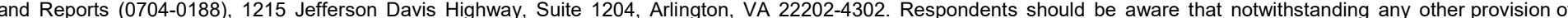
law, no person shall be subject to any penalty for failing to comply with a collection of information if it does not display a currently valid OMB control number.

PLEASE DO NOT RETURN YOUR FORM TO THE ABOVE ADDRESS.

\begin{tabular}{l|l|l}
\hline 1. REPORT DATE & 2. REPORT TYPE & 3. DATES COVERED (From - To) \\
December 2019 & Final Report
\end{tabular}

\section{TITLE AND SUBTITLE}

Wave Averaging for Scoping Level Estimates of Nearshore Berm Morphodynamics 5a. CONTRACT NUMBER

5b. GRANT NUMBER

5c. PROGRAM ELEMENT NUMBER

5d. PROJECT NUMBER

5e. TASK NUMBER

5f. WORK UNIT NUMBER

8. PERFORMING ORGANIZATION REPORT NUMBER

ERDC/CHL TR-19-23

10. SPONSOR/MONITOR'S ACRONYM(S) USACE

11. SPONSOR/MONITOR'S REPORT NUMBER(S)

\section{DISTRIBUTION/AVAILABILITY STATEMENT}

Approved for public release; distribution is unlimited.

\section{SUPPLEMENTARY NOTES}

Funding Account Code U4362900; AMSCO Code 060000

\section{ABSTRACT}

Nearshore berms beneficially use dredged sediment to retain sediment in the littoral system, add material to the beach profile, and potentially dissipate energy from large erosive waves. Scoping level estimates of nearshore berm morphodynamics could provide useful information to assist coastal engineers and planners. Methodologies are presented to use long records of wave hindcast data to determine representative peak and mean wave climate data for scoping level nearshore berm morphodynamic estimates. Representative mean wave climate data are selected from distributions of averages over specified durations. Representative peak wave climate data are selected from distributions of quarter year averages. The relevance of combinations of wave parameters to nearshore berm morphodynamics is addressed with further analysis of a large nearshore berm at Fort Myers Beach, FL. Estimates of nearshore berm morphodynamics were quantified from survey data. The migration direction of the case study nearshore berm was found to be described by the ratio of storm to non-storm wave energy flux time integrals. Evidence suggesting that the net volume of sediment transported in the littoral zone between surveys may be proportional to the time integral of the non-storm wave energy flux is also presented.

\section{SUBJECT TERMS}

Beach nourishment, Littoral drift, Sedimentation and deposition, Sediment transport, Shore protection, Ocean waves, Water waves

\section{SECURITY CLASSIFICATION OF:}

\begin{tabular}{|l|l|l|}
\hline a. REPORT & b. ABSTRACT & c. THIS PAGE \\
Unclassified & Unclassified & Unclassified \\
\hline
\end{tabular}

17. LIMITATION OF ABSTRACT

SAR
18. NUMBER

OF PAGES

80 19a. NAME OF RESPONSIBLE PERSON Douglas Krafft

19b. TELEPHONE NUMBER (Include area code) 601-634-6097 